US Army Corps of Engineers ${ }_{\circledast}$

Engineer Research and

Development Center

\title{
Elders Point East Marsh Island Restoration Monitoring Data Analysis
}

David S. Davis, Peter M. Weppler, Patricia Rafferty,

September 2017

Douglas G. Clarke, and David Yozzo 
The U.S. Army Engineer Research and Development Center (ERDC) solves the nation's toughest engineering and environmental challenges. ERDC develops innovative solutions in civil and military engineering, geospatial sciences, water resources, and environmental sciences for the Army, the Department of Defense, civilian agencies, and our nation's public good. Find out more at www.erdc.usace.army.mil.

To search for other technical reports published by ERDC, visit the ERDC online library at http://acwc.sdp.sirsi.net/client/default. 


\section{Elders Point East Marsh Island Restoration Monitoring Data Analysis}

David S. Davis and David Yozzo

$H D R$

1 International Boulevard

Suite 1000

Mahwah, NJ 07495

Peter M. Weppler

U.S. Army Corps of Engineers

New York District, Planning Division

26 Federal Plaza, Room 2151

New York, NY 10278-0090

Patricia Rafferty

National Park Service

Northeast Region

120 Laurel Street

Patchogue, NY 11772

Douglas G. Clarke

$H D R$

114 Westwood Drive

Vicksburg, MS 39183

Final report

Approved for public release; distribution is unlimited. [or a restricted statement]

Prepared for U.S. Army Corps of Engineers

Washington, DC 20314-1000

Under Project \#454750, “Elders Point East Marsh Island Restoration: Monitoring Data Analysis" 


\section{Abstract}

Chronic loss of intertidal salt marsh island habitat in Jamaica Bay, New York, has led to efforts by multi-agency partnerships to reduce loss through habitat restoration. A 2006 USACE New York District report recommended restoration of three marsh islands within the Jamaica Bay Unit of Gateway National Recreation Area: Elders Point East, Elders Point West, and Yellow Bar Hassock.

USACE New York District and its local sponsor, the Port Authority of New York and New Jersey, utilized sand obtained from navigation dredging and commercial sources to (1) return approximately 16 hectares (40 acres) of bay area to full Spartina alterniflora marsh and wetland functionality, and (2) test a suite of management practices to enhance the probability of long-term success.

Although the long-term success of the Elders Point East Marsh restoration project cannot be confirmed by the 2007-2012 term of post-construction monitoring, nearly all lines of evidence gathered to date indicate that the marsh is following a functional equivalency trajectory toward an endpoint comparable to reference conditions. In this case, the beneficial use of dredged material proved to be a viable option for restoration of sufficient habitat area to substantially enhance lost ecological function within the Jamaica Bay ecosystem.

DISCLAIMER: The contents of this report are not to be used for advertising, publication, or promotional purposes. Citation of trade names does not constitute an official endorsement or approval of the use of such commercial products. All product names and trademarks cited are the property of their respective owners. The findings of this report are not to be construed as an official Department of the Army position unless so designated by other authorized documents. 


\section{Contents}

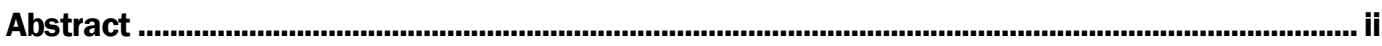

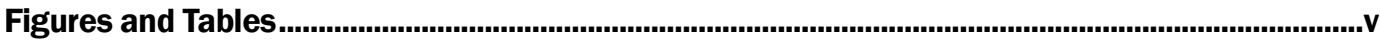

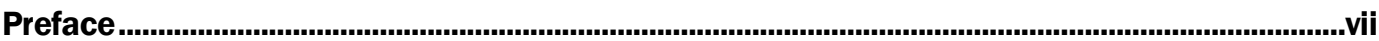

Unit Conversion Factors .................................................................................................................... vifi

Executive Summary ........................................................................................................................... ix

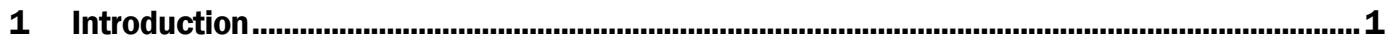

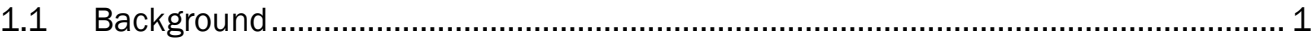

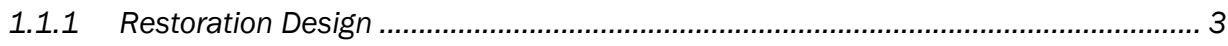

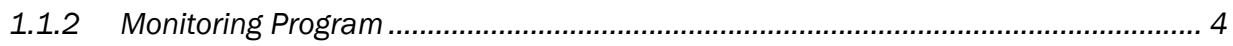

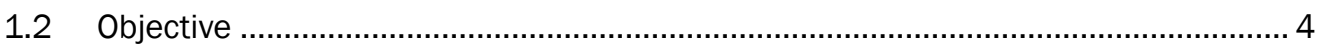

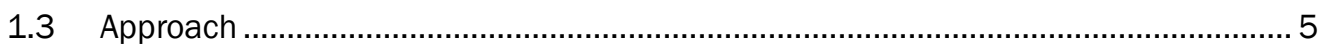

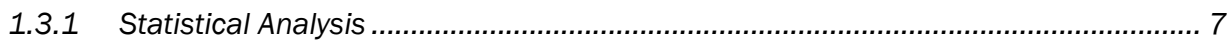

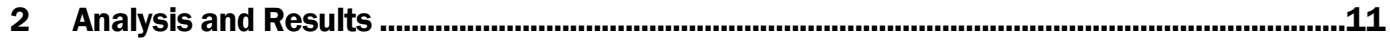

2.1 Sediment Elevation....................................................................................... 11

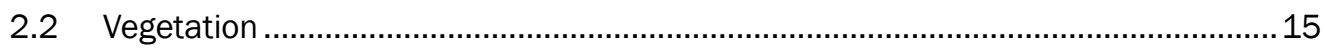

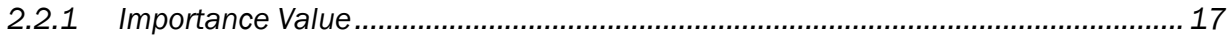

2.2.2 Percent Cover ..................................................................................................... 18

2.2.3 Stem Density and Condition (stem counts) .......................................................... 21

2.2.4 Height of Spartina alterniflora............................................................................ 22

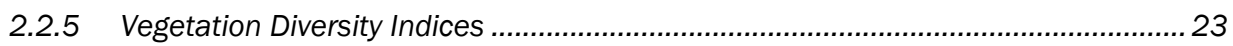

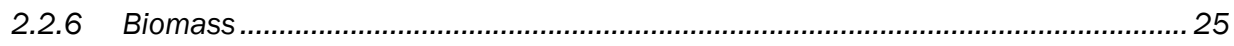

2.3 Benthic Macroinvertebrates............................................................................... 28

2.3.1 Community Composition....................................................................................... 29

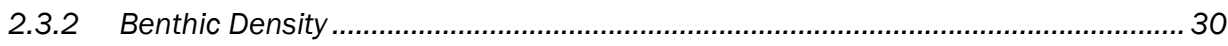

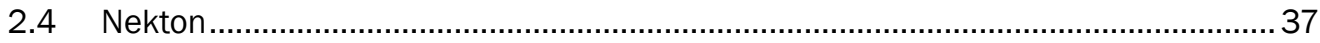

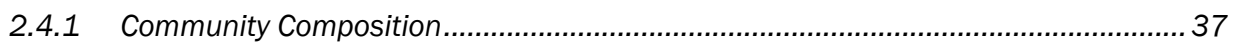

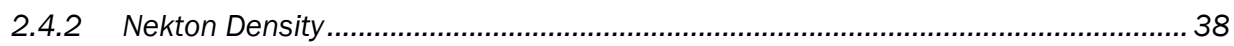

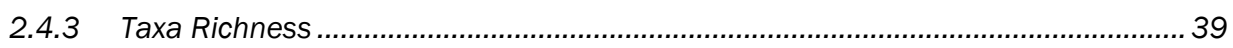

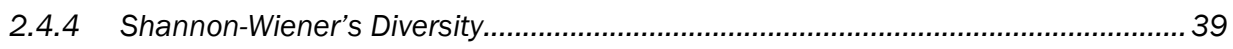

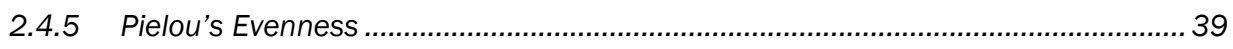

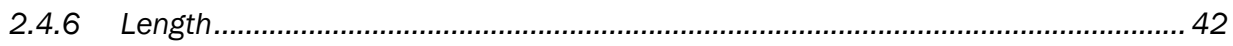

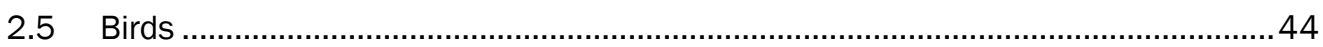

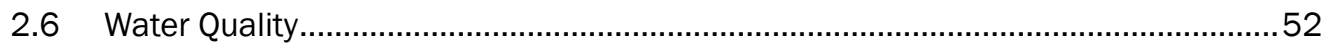

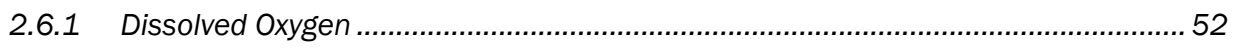

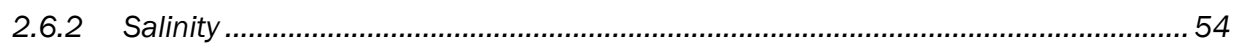

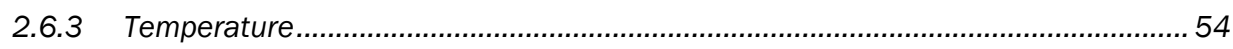

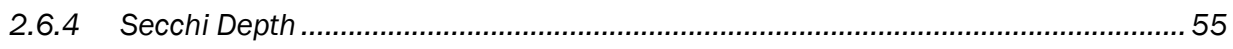

2.6.5 Fecal Coliform and Enterococci Bacteria................................................................ 55 


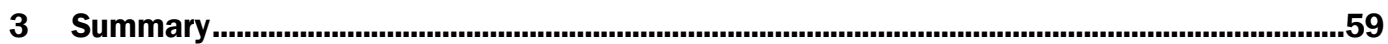

3.1 Hydrology and Sediment Movement Processes....................................................60

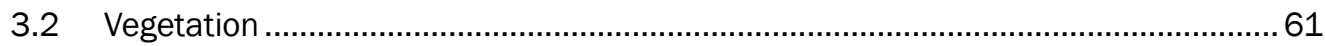

3.3 Other Biological and Physical Measures .............................................................65

$4 \quad$ Long-Range Future Recommendations..............................................................................68

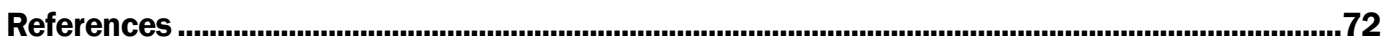

Appendix A …...................................................................................................................................77

Report Documentation Page 


\section{Figures and Tables}

\section{Figures}

Figure 1. Jamaica Bay overview map. 2

Figure 2. Vegetation plot sampling location overview map. ............................................................... 8

Figure 3. Nekton sampling location overview map. .......................................................................... 9

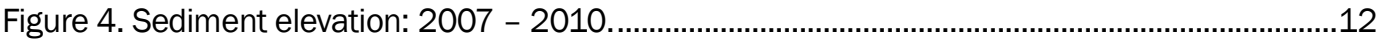

Figure 5. Tidal datums: 2007 - 2010 ...................................................................................................13

Figure 6. Water depth at mean high water: 2007 - 2010 ...............................................................14

Figure 7. Elevation change: 2007 - 2009 and 2009 - 2010...........................................................16

Figure 8. Importance value of plant species at Elders East and JoCo Marsh. ...................................19

Figure 9. Growth measurements at Elders East and JoCo Marsh. ..................................................20

Figure 10. Stem survival at Elders East and JoCo Marsh..................................................................22

Figure 11. Average height to leaf of live Spartina alterniflora at Elders East and JoCo

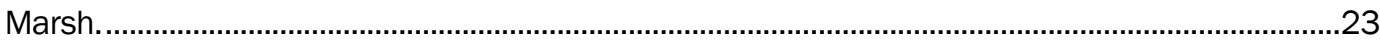

Figure 12. Ratio of average above ground biomass to below ground biomass at Elders East and JoCo Marsh .26

Figure 13. Average biomass comparison between fertilizer treatment and non-fertilizer treatment at Elders East.

Figure 14. Length-frequency distributions for most commonly measured invertebrate species collected in nekton samples at Elders Point monitoring sites, 2005 - 2010. (Continued) .43

Figure 14. (Concluded).

Figure 15. Dissolved oxygen $(\mathrm{mg} / \mathrm{L})$ measured during NYCDEP harbor quality survey at Station J8 (40.642833 N, 73.851167 W) near Elders Point East Site, 2005 - 2012. .54

Figure 16. Secchi transparency (ft.) measured during NYCDEP harbor quality survey at Station J8 (40.642833 N, 73.851167 W) near Elders Point East Site, 2005 - 2012.

Figure 17. Fecal coliform count (\#/100 mL) measured during NYCDEP harbor quality survey at Station 18 (40.642833 N, 73.851167 W) near Elders Point East Site, 2005 2012.

Figure 18. Enterococcus count (\#/100 mL) measured during NYCDEP harbor quality survey at Station J8 (40.642833 N, 73.851167 W) near Elders Point East Site, 2005 2012. .58

Figure 19. Total change in percent cover: 2006 - 2008 and 2008 - 2012. 63

\section{Tables}

Table 1. Elders Point East Monitoring Program Sites and Treatment Options for the Vegetation Restoration Design.....................................................................................................

Table 2. Ecological attributes monitored pre- and post-restoration of Elders East.............................. 6

Table 3. Vegetation and Nekton Plot summary table..........................................................................15

Table 4. Stem count live vegetation diversity indices, Elders Island monitoring sites, 2005 - 2012. 
Table 5. Count of benthic organisms collected at Elders Island monitoring sites, 2005-

2012.

Table 6. Benthic Community Indices: True Taxa Richness, Total Organism Count, Average

Density by Sample Plot (no. organisms / $\mathrm{m}^{2}$ ), Shannon-Weiner's Diversity $\left(\mathrm{H}^{\prime}\right)$, and Pielou's

Evenness (J'); Elders Island Monitoring Sites, 2005 - 2012.

Table 7. Average density by sampling plot (no. organisms $/ \mathrm{m}^{2}$ ) and percentage of total average density by phylum; benthic organisms at Elders Island monitoring sites, 2005 2012.

Table 8. Taxa richness and percentage of total taxa richness by phylum; benthic organisms at Elders Island monitoring sites, 2005 - 2012.

Table 9. Count of nekton collected at Elders Island monitoring sites, 2005-2010.

Table 10. Nekton community indices: true taxa richness, total organism count, average density by sample plot (no. organisms / $\mathrm{m}^{2}$ ), Shannon-Weiner's diversity $\left(\mathrm{H}^{\prime}\right)$, and Pielou's evenness (J'); Elders Island monitoring sites, 2005 - 2010.

Table 11. Minimum, maximum, and average length for measured individuals of all nektonic species collected at Elders Island monitoring sites, 2005 - 2010.

Table 12. Bird species observed by year, Elders Island monitoring sites, 2006 - 2010. ...................45

Table 13. Bird species observed by season, Elders Island monitoring sites, 2006 - 2010...............48

Table 14. Bird species observed by location, Elders Island monitoring sites, 2006 - 2010...............51

Table 15. Average physical water quality parameters recorded during nekton sampling;

Elders Island monitoring sites, 2005 - 2010. .53

Table A-1. Vegetation percent cover treatment comparison...................................................................77

Table A-2. Vegetation stem density treatment comparison. ...............................................................77

Table A-3. Vegetation Stem Height Treatment Comparison. ……......................................................78

Table A-4. Vegetation aboveground biomass treatment comparison.................................................78

Table A-5. Vegetation belowground biomass $(0-15 \mathrm{~cm})$ treatment comparison.................................79

Table A-6. Vegetation belowground biomass $(15-30 \mathrm{~cm})$ treatment comparison. …….....................79

Table A-7. Benthic density treatment comparison. .......................................................................80

Table A-8. Nekton early summer (event 1) density treatment comparison. ........................................80

Table A-9. Nekton late summer (event 2) density treatment comparison. ........................................81

Table A-10. Water quality early summer (event 1 ) dissolved oxygen treatment comparison.............81

Table A-11. Water quality late summer (event 2) dissolved oxygen treatment comparison..............82

Table A-12. Water quality early summer (event 1) salinity treatment comparison. ............................82

Table A-13. Water quality late summer (event 2) salinity treatment comparison..............................83

Table A-14. Water quality early summer (event 1) temperature treatment comparison....................83

Table A-15. Water Quality Late Summer (Event 2) Temperature Treatment Comparison...................84 


\section{Preface}

This report presents the results of a study conducted by the U.S. Army Engineer New York District (CENAN) in cooperation with the U.S. Park Service under Project number 454750, "Elders Point East Marsh Island Restoration: Monitoring Data Analysis.”

The work was performed by a multi-agency team, which included Dr. Douglas Clarke of the Wetlands and Coastal Ecology Branch (EE-W) of the Ecosystem Evaluation and Engineering Division (EE), US Army Engineer Research and Development Center, Environmental Laboratory (ERDC-EL). At the time of publication, Ms. Patricia Tolley was Chief, CEERD-EEW; Mr. Mark Farr was Chief, CEERD-EE. This report was published under the technology transfer function of the Dredging Operations Technical Support Program (DOTS); Dr. Burton Suedel is Program Manager. At the time of publication, the Deputy Director of ERDCEL was Dr. Jack Davis and the Director was Dr. Beth Fleming.

COL Bryan S. Green was the Commander of ERDC, and Dr. David W. Pittman was the Director of ERDC. 


\section{Unit Conversion Factors}

\begin{tabular}{|l|l|l|}
\hline Multiply & By & To Obtain \\
\hline feet & 0.3048 & meters \\
\hline hectares & $1.0 \mathrm{E}+04$ & square meters \\
\hline inches & 0.0254 & meters \\
\hline quarts (U.S. liquid) & $9.463529 \mathrm{E}-04$ & cubic meters \\
\hline
\end{tabular}




\section{Executive Summary}

Chronic loss of intertidal salt marsh island habitat in Jamaica Bay, New York, has led to efforts by multi-agency partnerships to reduce loss through habitat restoration. In response to these losses, under the U.S. Army Corps of Engineers' Continuing Authorities Program (CAP), the New York City Department of Environmental Protection and the New York State Department of Environmental Conservation requested assistance in implementing one or more marsh island restoration projects. A 2006 report prepared by the U.S. Army Corps of Engineers New York District titled "Jamaica Bay Marsh Islands, Jamaica Bay, NY, Integrated Ecosystem Restoration Report" recommended restoration of three marsh islands within the Jamaica Bay Unit of Gateway National Recreation Area: Elders Point East, Elders Point West and Yellow Bar Hassock. As part of the mitigation requirements to offset environmental impacts associated with the New York and New Jersey Harbor Deepening Project, the New York District and its local sponsor, the Port Authority of New York and New Jersey, restored approximately 16 ha (40 acres) of Elders East Marsh Island in 2006-2007 with the stated objectives of (1) returning approximately 16 ha (40 acres) of bay area to full Spartina alterniflora marsh and wetland functionality, and (2) testing a suite of management practices to enhance the probability of long-term success. Sand obtained from navigation dredging and commercial sources was placed at the Elders Point East site to raise the island surface to a suitable elevation for Spartina alterniflora establishment.

Monitoring of baseline, during-, and post-construction conditions included a variety of physical and biological parameters and performance indicators. Post-construction monitoring was completed in 2012. By that point in time, most vegetation structural characteristics (i.e., plant height, stem density, percent cover and aboveground biomass) were comparable values obtained from a reference site (JoCo Marsh). Belowground biomass, however, remained lower than measured reference conditions. This observation was consistent with the longer functional equivalency trajectory associated with mature root system development at other marsh restoration sites in the region. With regard to the development of marsh structural attributes that support fauna, the Elders Point East Marsh in 2012 appeared to be providing suitable habitat for characteristic macroinvertebrate and fish assemblages. In particular, the high relative abundance of juvenile fishes indicated that the marsh served as nursery habitat. 
The experience gained at the Elders Point East Marsh restoration site provides opportunities to transfer knowledge and "lessons learned" to future projects in Jamaica Bay within an adaptive management context. For example, addition of a soil amendment such as fertilizer was deemed only partially successful, and may not necessarily represent the best use of limited project resources and funding in future efforts. In contrast, fencing to limit grazing pressure by geese and other waterfowl was determined to be a valuable management practice, ensuring optimal vegetation establishment conditions, and is strongly recommended for future efforts.

Although the long-term success of the Elders Point East Marsh restoration project cannot be confirmed by the 2007-2012 term of post-construction monitoring, nearly all lines of evidence gathered to date indicate that the marsh is following a functional equivalency trajectory toward an endpoint comparable to reference conditions. In this case, the beneficial use of dredged material proved to be a viable option for restoration of sufficient habitat area to substantially enhance lost ecological function within the Jamaica Bay ecosystem. 


\section{Introduction}

\subsection{Background}

The Jamaica Bay ecosystem is part of the Gateway National Recreation Area, a unit of the National Park Service (NPS), and is connected to the Lower Bay of New York Harbor by Rockaway Inlet (Figure 1).

Urbanization of the Rockaway Beach barrier island, including the stabilization of the inlet by jetties and the dredging of navigation channels, has modified hydrodynamics within the bay and resulted in an increased tidal range that prolongs inundation of marsh plants within Jamaica Bay and exacerbates erosion (Swanson and Wilson 2008, Messaros et al. 2010). In addition, the present rate of sediment supply to the marshes may be insufficient to maintain marsh elevation, given the long-term trends of regional sea level rise and shallow subsidence caused by high nutrient inputs into Jamaica Bay (Rafferty et al. 2010). The loss of wetlands has had a cumulative, negative effect on the water quality and wildlife habitat of Jamaica Bay (USACE-NYD 2007).

Since the first-half of the $20^{\text {th }}$ century, more than $60 \%$ of the vegetated salt-marsh islands, an estimated 650 ha $(1,600$ acres) in total, have been lost within Jamaica Bay, a process that continues at an estimated current rate loss of 7.7 ha (19 acres) per year (Rafferty et al. 2010).

In 2001, a Blue Ribbon Panel of scientists was assembled by the NPS to investigate the causes of marsh loss in Jamaica Bay and to develop a strategy for restoring the lost marshes. The panel's final report (NPS 2001) identified two primary mechanisms of marsh loss, including erosion around the shoreline and interior ponding/submergences. The panel postulated the reasons for the salt marsh decline are varied but are primarily related to sea level rise, sediment deprivation, dredging and shoreline hardening activities, mussel beds along marsh edges, nutrient enrichment, and proliferation of sea lettuce (Ulva sp.), waterfowl grazing, and boat traffic. 


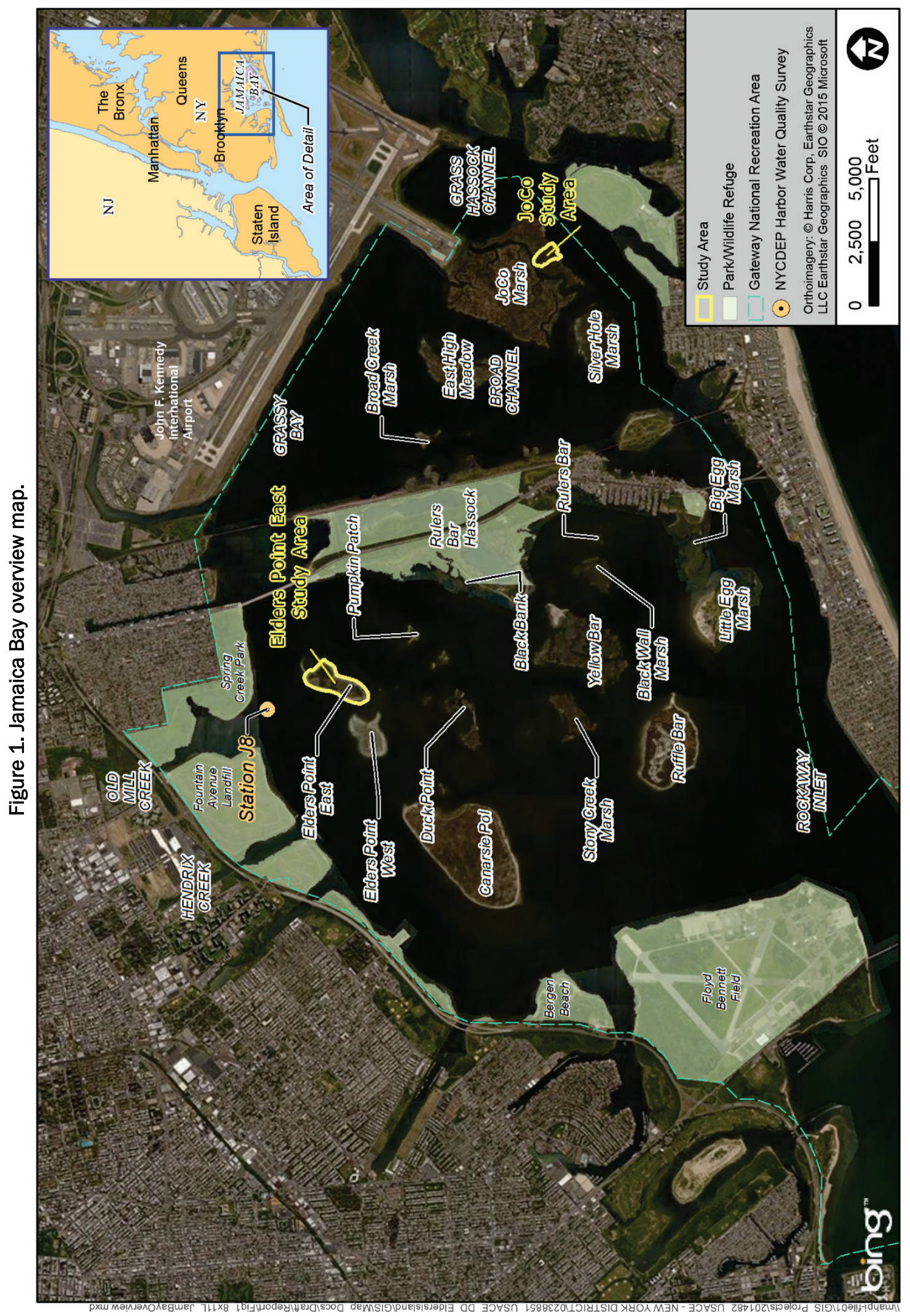


As a direct outcome of the panel's recommendations, a number of marsh restoration projects have been initiated within Jamaica Bay, including the restoration efforts of a multi-agency group led by the U.S. Army Corps of Engineers - New York District, New York City Department of Environmental Protection (NYCDEP), New York State Department of Environmental Conservation (NYSDEC), and the NPS to restore 16 ha (40 acres) of tidal wetlands at Elders East in the northeastern corner of the bay. Elders Point Marsh was historically one island, but marsh loss in the center of the island created two distinct islands separated by a mud flat (USACE-NYD 2006). Since 1951, an estimated 53 ha (131 acres) - or 92\% of the marsh island has been lost (GNRA \& JBWPPAC 2007).

\subsubsection{Restoration Design}

Construction of the Elders East restoration took place in 2006-2007 serving as environmental mitigation for the New York and New Jersey Harbor Deepening project, thus the design criteria at this site strictly followed traditional USACE and NYSDEC wetland restoration design standards. Restoration was accomplished through the beneficial placement of dredged material (>95\% sand) obtained from Rockaway Inlet and Ambrose Channel with additional sand purchased from Amboy Aggregate. Restoration efforts included the placement of fill material, regrading the site to appropriate elevations, and the planting of native coastal plant species to emulate the approximate extent of marsh coverage in 1974 as mapped by NYSDEC based on analysis of aerial photographs.

Prior to the restoration, Elders East was comprised of 25 ha (61.8 acres) of mudflats; 2.1 hectares (5.3 acres) of low marsh vegetation (dispersed over a 5-hectare area); and 1.9 ha (4.7 acres) of upland. The selected plan for Elders East included restoring the existing vegetated areas and the sheltered and exposed mudflats out to the 1974 footprint of marsh coverage (USACE-NYD 2007).

The restoration of existing bands of fragmented low marsh vegetation was achieved via the strategic placement of material to an elevation that was suitable for low marsh growth. Fill material was placed between the hummocks of existing vegetation and in such a manner as to minimize damage to the existing vegetation. Spartina alterniflora (smooth cordgrass) was planted throughout the site in the elevation range from 1.5 to $2.25 \mathrm{ft}$ (elevations are referenced to the North American Vertical Datum of 1988 (NAVD88)) at a spacing of $18 \mathrm{in}$. on center. Along the perimeter of the 
island, in areas that were identified as high energy, a 20-foot band of Spartina alterniflora was planted. In these high energy areas, one-quart pot-sized plants were installed on either 12- or 18-inch centers. All other plantings were 2-inch plugs. In the elevation zones between low marsh and upland (2.25 to $3.3 \mathrm{ft}$ ), a mixture of Spartina alterniflora, Spartina patens (saltmeadow hay), and Distichlis spicata (saltgrass) was planted in single holes. With the exception of a planned unfertilized treatment area on the southwest side of the island, all planted vegetation was fertilized with 18:6:11 Osmocote slow release fertilizer at a rate of $15 \mathrm{~g}$ per plug and $30 \mathrm{~g}$ per quart pot.

In addition, approximately 0.6 ha (1.5 acres) of existing smooth cordgrass from Elders Point East were relocated within the island as part of the restoration and offered an opportunity to evaluate a method of revegetation that conserved existing marsh vegetation, including the underlying intact benthic community (Rafferty et al. 2010).

\subsubsection{Monitoring Program}

Pre-restoration monitoring occurred in 2005 at Elders East and in an area of JoCo Marsh considered representative of the target or reference condition (USACE-NYD 2007). Five years of pre- and post-construction monitoring was originally scheduled to occur, but due to the construction activities taking two seasons, an extra year of partial monitoring was obtained. The year 2006 was designated Target Year $o$ and, starting in 2007, all marsh island construction activities were completed and postrestoration monitoring began. Post-construction monitoring was completed by the fall of 2012 (see Timeline above).

\subsection{Objective}

The objectives of the monitoring were therefore to determine factors contributing to the success or failure of the restoration; to test various planting techniques (Table 1); to justify adaptive management actions; and to better understand factors contributing to marsh loss throughout Jamaica Bay (Rafferty et al. 2010). 
Table 1. Elders Point East Monitoring Program Sites and Treatment Options for the Vegetation Restoration Design.

\begin{tabular}{|c|c|c|c|c|c|c|c|}
\hline \multirow[b]{2}{*}{ Site } & \multirow[b]{2}{*}{ Treatment } & \multirow{2}{*}{$\begin{array}{l}\text { Start } \\
\text { Year }\end{array}$} & \multirow[b]{2}{*}{ End Year } & \multicolumn{4}{|c|}{ Treatment Options } \\
\hline & & & & Marsh Type & Fill & Plant & Fertilize \\
\hline JoCo & Control / Reference & 2005 & 2012 & Low $^{1}$ & & & \\
\hline \multirow{5}{*}{ Elders East } & Full Restoration & 2005 & 2012 & Low & $x$ & $x$ & $x$ \\
\hline & Fertilization & 2007 & 2012 & Low & $x$ & $x$ & $x$ \\
\hline & No Fertilization & 2007 & 2012 & Low & $x$ & $x$ & \\
\hline & Relocation 1 & 2007 & 2012 & Low & $x$ & & $x$ \\
\hline & Relocation 2 & 2007 & 2012 & Low & $x$ & & $x$ \\
\hline
\end{tabular}

1 JoCo Marsh is primarily characterized by a mix of high marsh species with some Spartina alterniflora. However, the reference area chosen was mainly low marsh habitat consistent with the restoration project area (USACE-NYD 2007).

\subsection{Approach}

The goals of monitoring the marsh island restoration were to quantify the degree of success of the restoration and to determine factors that contributed to the relative success or failure of the project. To accomplish these goals, the restoration design and monitoring program incorporated an investigative approach to evaluate alternatives that could guide future restoration efforts.

Because hydrology and sediment elevation are the primary driving forces behind wetland formation and maintenance, altered hydrology will ultimately dictate changes in sediment elevation, wetland boundaries, substrate composition and the long-term viability of vegetation species and wetland macro fauna. Several ecological attributes were therefore monitored pre- and post-restoration at the Elders East treatment locations and the JoCo reference marsh. For each general attribute, several specific parameters - or indicators - were identified to specifically characterize the performance of the marsh ecosystems (Table 2). The critical information to be gained from the analysis was a better understanding of the important environmental and biotic features that contribute to salt marsh restoration success and a diverse salt marsh community. The general attributes monitored included:

- Sediment Elevation,

- Vegetation,

- Benthic Macroinvertebrates,

- Nekton,

- Birds, and

- Water Quality. 
Table 2. Ecological attributes monitored pre- and post-restoration of Elders East.

\begin{tabular}{|c|c|c|c|c|}
\hline Criteria & Parameters & Monitoring Locations & Attributes & Protocol \\
\hline \multirow{7}{*}{ Physical } & \multirow{7}{*}{ Sediment } & Jamaica Bay & Elevation & Continuous Survey \\
\hline & & Permanent Vegetation Plots & Elevation $^{1}$ & Areal Survey \\
\hline & & \multirow{5}{*}{ Stratified-Random Nekton Plots } & Location, Time & Point Measurement \\
\hline & & & Dissolved Oxygen & Point Measurement \\
\hline & & & Depth & Point Measurement \\
\hline & & & Salinity & Point Measurement \\
\hline & & & Temperature & Point Measurement \\
\hline \multirow{13}{*}{ Flora } & \multirow{6}{*}{ Stem Count ${ }^{1}$} & \multirow{4}{*}{ Permanent Vegetation Plots } & Location, Time & Point Measurement \\
\hline & & & Plant Species & Field ID \\
\hline & & & Plant Type & Field ID \\
\hline & & & Stem Count & Field Count \\
\hline & & \multirow{2}{*}{$\begin{array}{l}\text { Permanent Vegetation Plot } \\
\text { Quadrants }\end{array}$} & Plant Height ${ }^{2}$ & Point Measurement \\
\hline & & & Plant Part ${ }^{2}$ & Field ID \\
\hline & \multirow{3}{*}{ Point Intercept } & \multirow{3}{*}{ Permanent Vegetation Plots } & Location, Time & Point Measurement \\
\hline & & & Species & Field ID \\
\hline & & & Count & Field Count \\
\hline & \multirow{4}{*}{ Biomass } & \multirow{4}{*}{ Permanent Vegetation Plots } & Location, Time & Point Measurement \\
\hline & & & $\begin{array}{l}\text { Aboveground } \\
\text { biomass }\end{array}$ & Sample Analysis \\
\hline & & & $\begin{array}{c}\text { Belowground } \\
\text { biomass (0-15") }\end{array}$ & Sample Analysis \\
\hline & & & $\begin{array}{l}\text { Belowground } \\
\text { biomass (15-30") }\end{array}$ & Sample Analysis \\
\hline \multirow{10}{*}{ Fauna } & \multirow{4}{*}{ Nekton } & \multirow{4}{*}{ Stratified-Random Nekton Plots } & Location, Time & Point Measurement \\
\hline & & & Species & Field ID \\
\hline & & & Count & Field Count \\
\hline & & & Length ${ }^{3}$ & Point Measurement \\
\hline & \multirow{3}{*}{ Benthic } & \multirow{3}{*}{ Permanent Vegetation Plots } & Location, Time & Point Measurement \\
\hline & & & Species & Field ID \\
\hline & & & Count & Field Count \\
\hline & \multirow{3}{*}{ Birds } & \multirow{3}{*}{ Permanent Bird View Locations } & Location, Time & Point Measurement \\
\hline & & & Species & Field ID \\
\hline & & & Count & Field Count \\
\hline
\end{tabular}

1Elders East Island sediment elevation was surveyed in 2007, 2009, and 2010. Elevations of individual plots were interpreted from elevation survey data. See Section 2.1 Elevation for more information.

2The three tallest Spartina alterniflora per quadrant were measured.

3The first 15 organisms of each nekton species were measured per plot survey. 
Vegetation monitoring focused on measurement of individual plant structural characteristics such as species composition, stem count, maximum plant height, and percent cover as well as above- and belowground biomass. These vegetation parameters, along with soil type and hydrologic conditions, have been established as useful indicators of wetland functions (Neckles and Dionne 2000, Sturdevant et al. 2002, Craft et al. 2003). Each parameter will vary in response to environmental gradients such as depth and duration of flooding, salinity regime, and nutrient characteristics of the wetland habitat. Macrofauna sampling included quantifying the abundance and composition of benthic macroinvertebrate, nekton and avian communities along with tallying opportunistic observations of mammals, reptiles, and amphibians.

To facilitate accomplishing the monitoring objectives, a survey grid was created as a framework for locating sampling points. This grid was comprised of one baseline and several perpendicular transects. The remaining transects were apportioned at equal distances along the baseline to cover the entire restoration site including the various vegetative treatment locations (Figure 2) and for the randomly selected nekton sampling locations (Figure 3). Spacing of the vegetative plots was determined based upon the sample area to achieve greater than 25 permanent plots per treatment location. However, due to the small treatment area (approximately two acres (o.8 hectares) each), sample size for the relocation treatments was less than 25 .

\subsubsection{Statistical Analysis}

Appendix A includes the results for the various statistical analyses performed with PRIMER version 7.0.5 (Clarke and Warwick 2001) using data collected and provided by (NPS). The analytical process generally consisted of the following:

- The appropriate units were calculated from observed measurements;

- The data was transformed (e.g., square root, $\log (\mathrm{x}+1)$, or arcsine) and normalized as appropriate for the data type;

- A resemblance matrix was calculated using a Bray-Curtis Similarity or Euclidian Distance measure as appropriate for the data type; and

- A univariate one-way Analysis of Similarity (ANOSIM) was completed by unordered Site and Year using Spearman rank with a maximum of 999 permutations. 


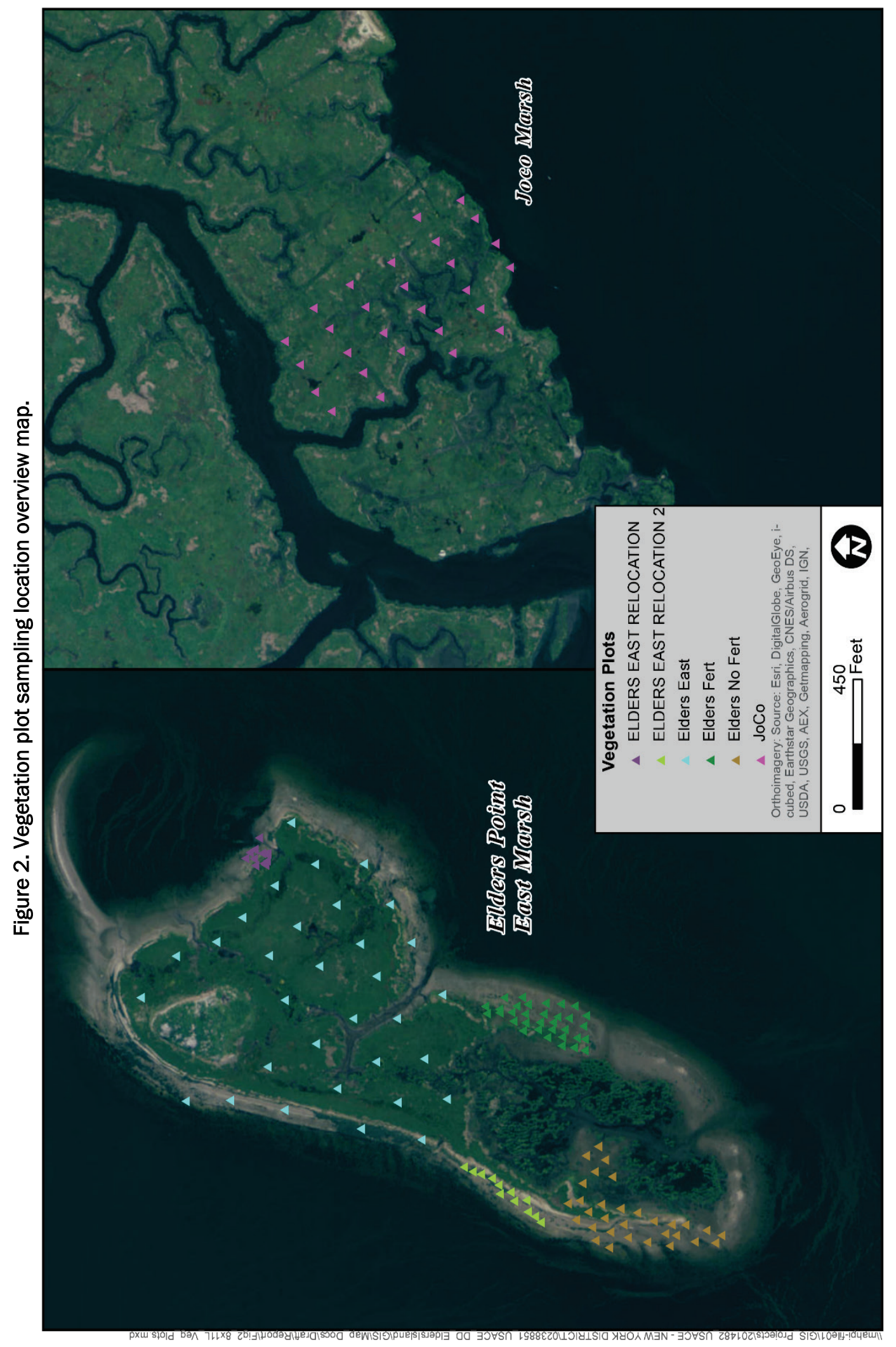




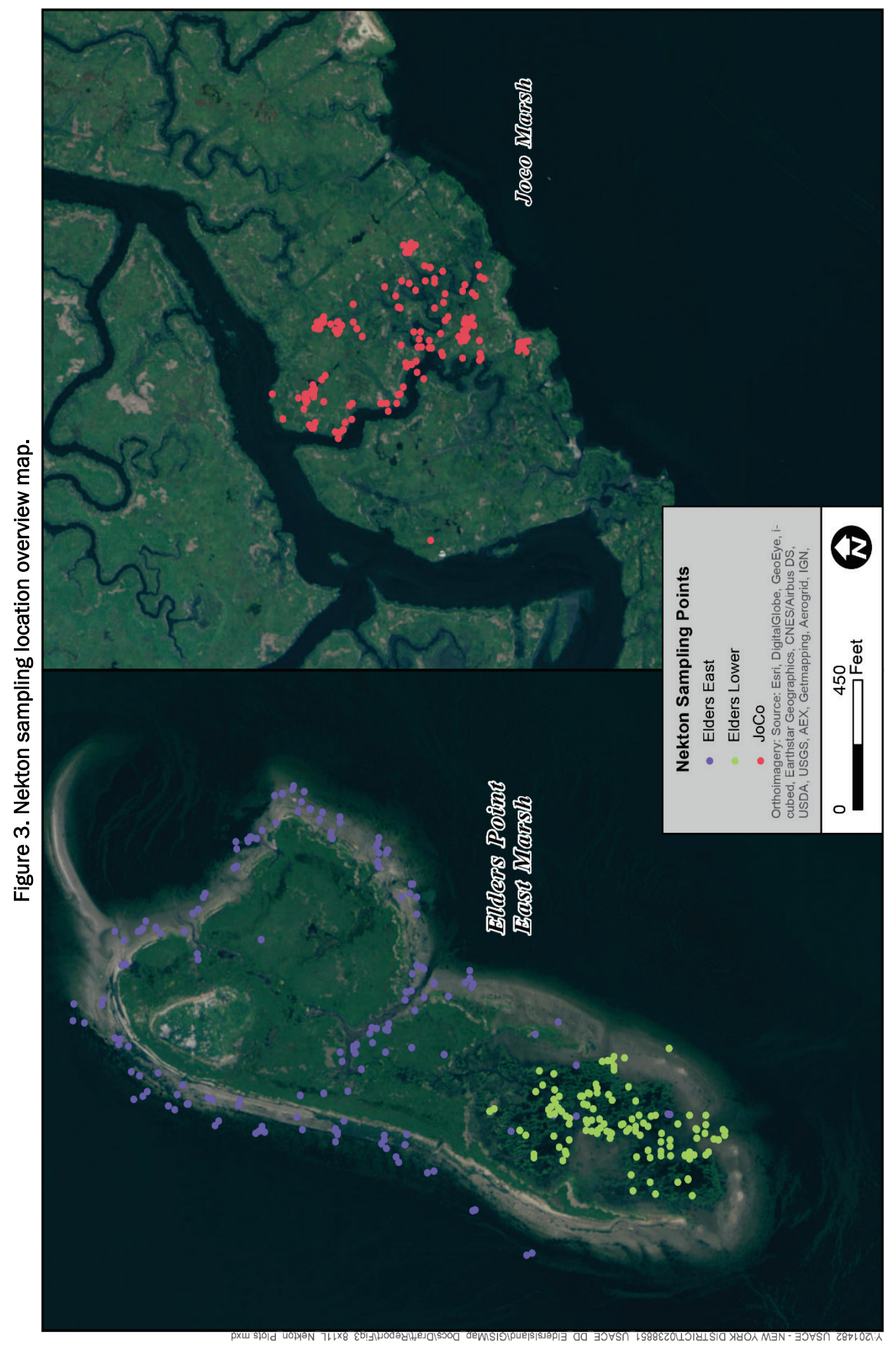


For parameters that distinguished species, only total values were compared among sites to maintain univariate comparisons. The resulting sample statistics and significance levels were reported by year for each combination of comparable sites. A significance threshold was set at $p<0.05$. 


\section{Analysis and Results}

\subsection{Sediment Elevation}

Post-construction sediment elevation data were collected in 2007, 2009, and 2010 using real-time kinetic global positioning system (RTK-GPS) survey equipment. Sediment elevation data collection was focused along the perimeter of the island where it was anticipated that sediment transport would be most active. Elevation data points were typically collected every $30 \mathrm{ft}(9.1 \mathrm{~m})$ along profile lines spaced approximately $100 \mathrm{ft}(30.5 \mathrm{~m})$ apart and had a vertical accuracy of approximately $+/-5$ centimeters ( $\mathrm{cm}$, or $2 \mathrm{in}$.) at the survey locations. The point data collected in 2007, 2009, and 2010 were used to develop digital elevation models (DEMs) using tools available in ArcGIS Desktop. First, a boundary encompassing the majority of data for all three years was developed so that the extent of the DEMs would be consistent for all three years. The interior of the island was omitted from the 2010 DEM because few data were collected in that area during the 2010 survey. Point elevation data were interpolated using the ArcGIS spatial analyst tool "Topo to Raster" with a 10-foot $(3 \mathrm{~m})$ cell size. This method resulted in a continuous DEM for each survey year (Figure 4), which was useful for examining features and changes in elevation among years.

Figure 5 presents the island's elevation relative to tidal datum, ranging from Mean Higher High Water (MHHW) - when most of the island would be inundated except for the sand spit on the northwest tip of the island to Mean Lower Low Water (MLLW) - when all of the island lies exposed. The sand spit was not planted with vegetation as part of the current tidal marsh restoration effort. In addition, the core of the island sits at an elevation between Mean Sea Level (MSL) and Mean High Water (MHW) with the northeast corner and portions of the southern tip extending into the central core of the island inundated from Mean Low Water (MLW) to MSL. At MHW, the northeast corner of the island and a large portion of the southern central core are inundated with upwards of one to two ft of water, compared to the western shore and northern core of the marsh, which receives half a foot or less at MHW (Figure 6). 


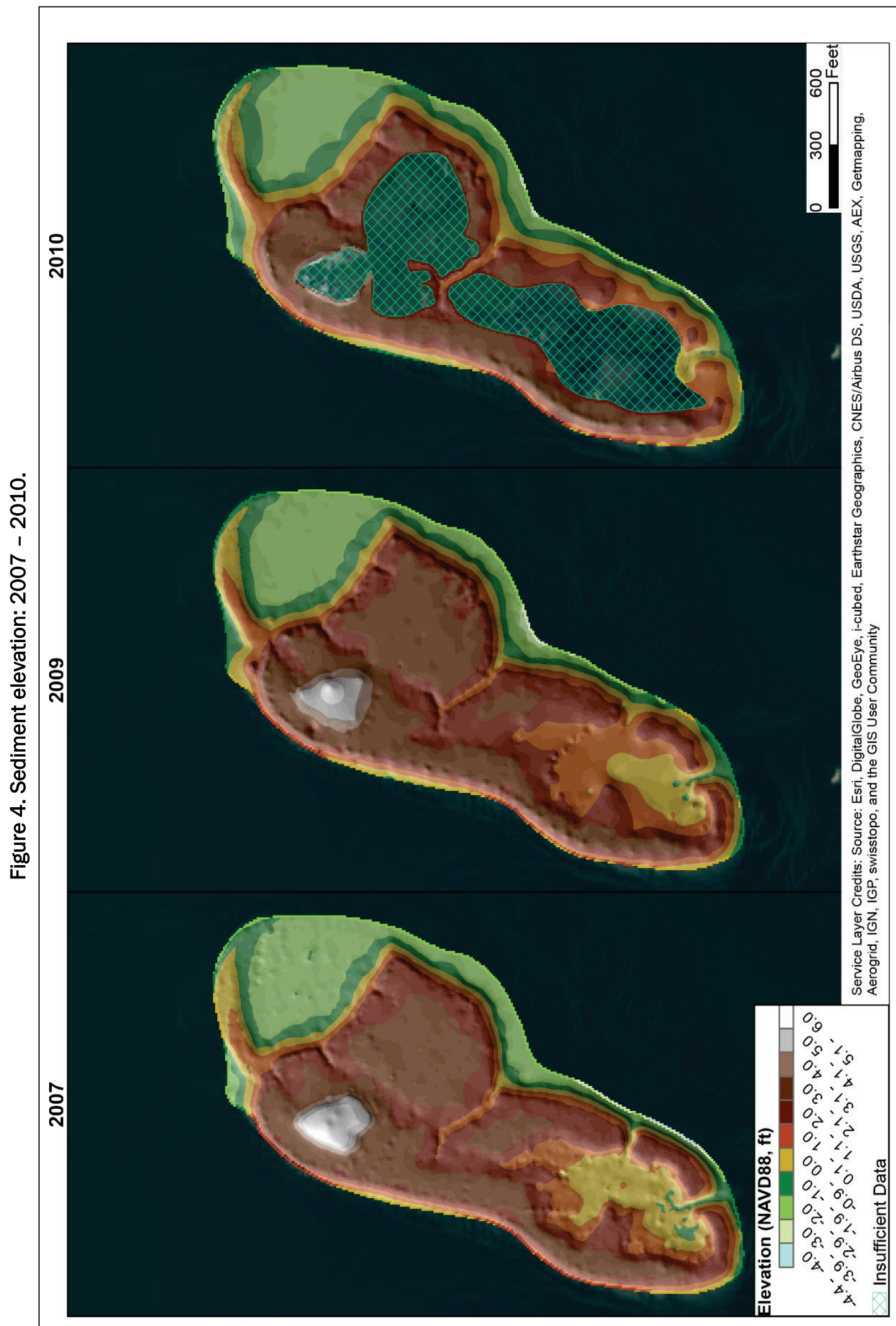

рхш әәииечว 


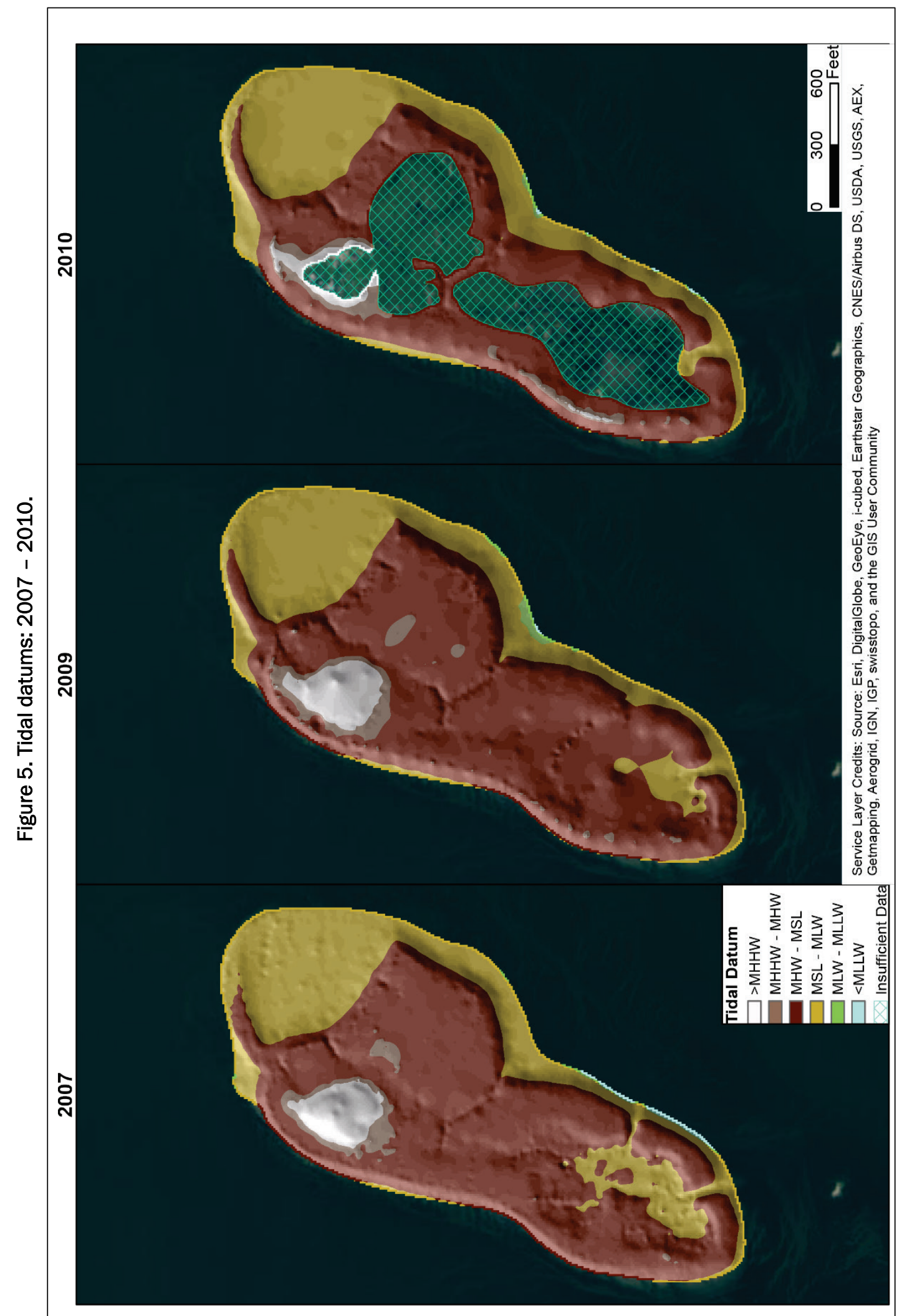

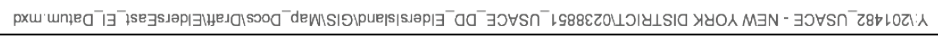




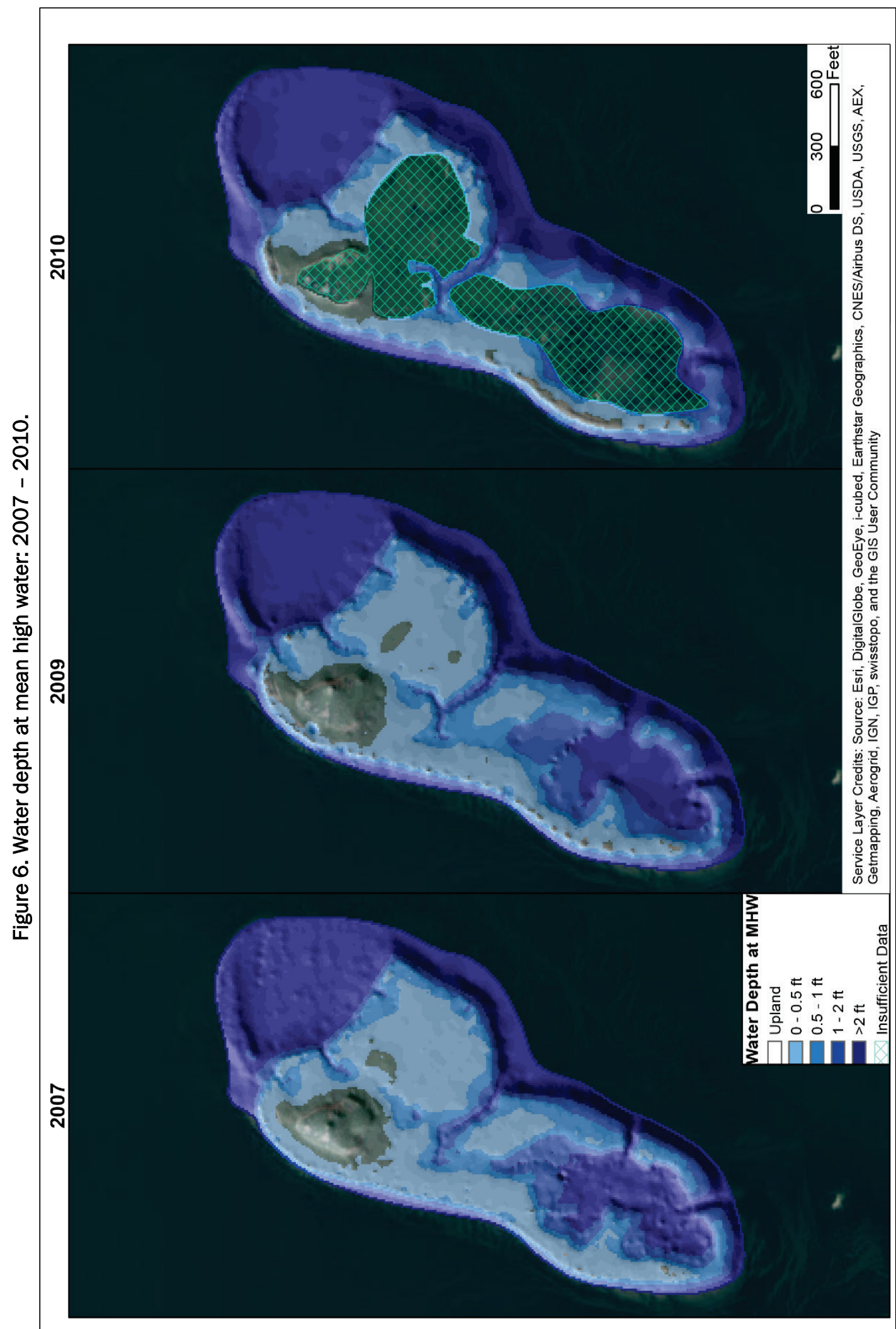

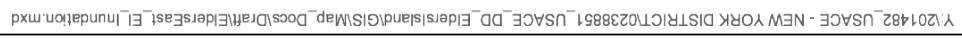


Patterns of sediment elevation change (erosion and deposition) from 2007 to 2009 and from 2009 to 2010 are shown in Figure 7. Observed patterns of loss along the western shore (typically between 0.25 and $1.0 \mathrm{ft}$ ) and net gains (up to $1.0 \mathrm{ft}[0.3 \mathrm{~m}]$ ) were focused in the northeast corner and south central portions of the island and are likely reflective of the tidal energy and geophysical forces acting upon the marsh island.

\subsection{Vegetation}

Vegetation data were evaluated at permanent vegetation plots during each annual sampling event at Elders East and JoCo Marshes (Table 3).

Vegetation monitoring followed the protocol described by Roman et al. (2001). Vegetation measurements were collected at permanent plot locations positioned along each sample transect at predetermined, regularly spaced distances (Figure 3). Plots were one meter by one meter and percent cover was sampled annually, using a point interceptor methodology within the permanent plots. Point intercept data were collected in accordance with standard operating procedures using meter sticks, dowels marked at $10 \mathrm{~cm}$ intervals, and a metal point intercept rod.

Table 3. Vegetation and Nekton Plot summary table.

\begin{tabular}{|c|c|c|c|c|}
\hline \multirow[b]{2}{*}{ Site } & \multirow[b]{2}{*}{ Treatment } & \multirow[b]{2}{*}{ Years Monitored } & \multicolumn{2}{|c|}{ Number of Plots } \\
\hline & & & Vegetation $^{1}$ & Nekton ${ }^{2}$ \\
\hline Joco & Control & 6 & 28 & 15 \\
\hline Elders East & Pre-Construction & 1 & 34 & 15 \\
\hline \multirow{5}{*}{ Elders East } & Full Restoration & 5 & 33 & \multirow{5}{*}{30} \\
\hline & Fertilization & 5 & 33 & \\
\hline & No Fertilization & 5 & 31 & \\
\hline & Relocation 1 & 5 & 12 & \\
\hline & Relocation 2 & 5 & 12 & \\
\hline
\end{tabular}

1 Vegetation plots were sampled once yearly

${ }^{2}$ Nekton plots were sampled twice yearly and varied slightly in total number of plots between years

Every other vegetation plot had an associated clip plot $\left(15 \mathrm{~cm}^{2}\right.$ in 2005 and 2006; and $25 \mathrm{~cm}^{2}$ in all subsequent years) and a soil core (6-inch radius $(15 \mathrm{~cm}), 30 \mathrm{~cm}$ depth) to evaluate biomass. Vegetation data and samples were collected during the peak biomass production period, which occurs from approximately mid-August to October. 


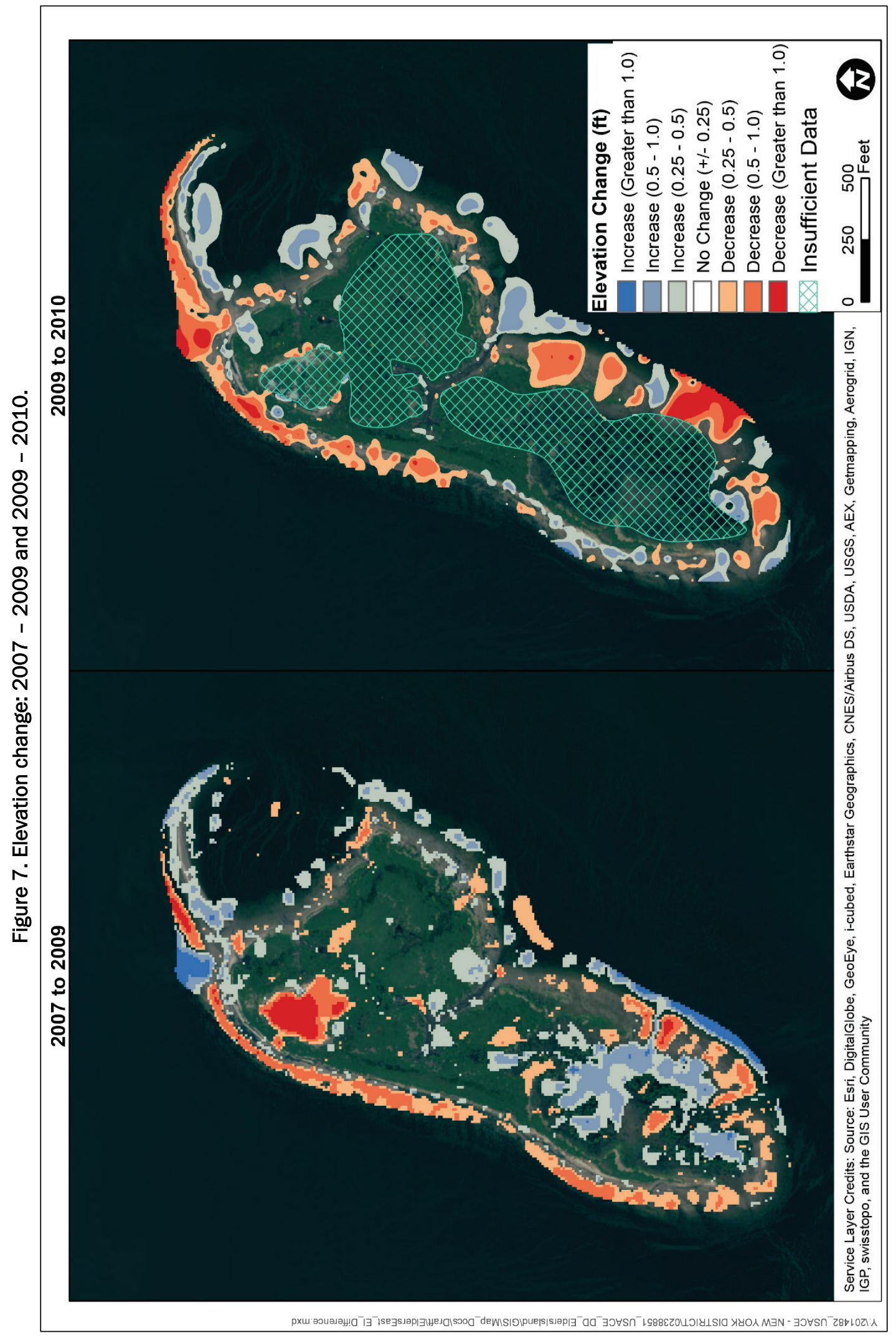


Associated with each sampled plot, individual plant characteristics such as species, stem count, and plant height were recorded and the following vegetative community metrics calculated and evaluated:

- Importance value

- Percent cover of live species

- Stem density and condition (from stem count)

- Maximum plant height of Spartina alterniflora

- Species richness, diversity, and heterogeneity

- Biomass (above and belowground)

\subsubsection{Importance Value}

Importance value refers to a group of measurements by which the species in a community can be compared and describes the relative contribution of each species to the entire plant community at a site. Importance value includes several metrics to balance species that have greater areal coverage with those that are numerically dominant at a site (Brower, Zar, and von Ende 1997).

Plant populations can be compared with respect to coverage (percentage of ground surface over which foliage of a species occurs) and frequency (percentage of sampling plots within the community in which a species is present) as an indication of how the marsh or resource space is partitioned among species.

For this project, an importance value was calculated for each species as the average of the relative percent cover and relative frequency from the pointintercept data. Importance values can range from $0 \%$ (least important) to 100\% (most important).

The equations used are as follows:

Relative Percent Cover $\left(\mathrm{RC}_{\mathrm{k}}\right)=\frac{C_{k}}{\sum_{1}^{(n)} C_{k}}$

Relative Frequency $\left(\mathrm{RF}_{\mathrm{k}}\right)=\frac{F_{k}}{\sum_{1}^{(n)} F_{k}}$

Importance Value $\left(\mathrm{IV}_{\mathrm{k}}\right)=\frac{\mathrm{RC}_{k}+\mathrm{RF}_{k}}{2}$ 
Where,

$$
\begin{aligned}
\mathrm{C}_{\mathrm{k}} & =\text { Average Percent Cover of the } k^{\text {th }} \text { species } \\
\mathrm{F}_{\mathrm{k}} & =\text { Average Frequency of the } k^{\text {th }} \text { species } \\
n & =\text { Total number of species }
\end{aligned}
$$

Figure 8 denotes the importance value of the most common plant species at both Elders East and JoCo Marshes in each surveyed year. The reference marsh represents a mature and diverse salt marsh with between 62 and $71 \%$ of the yearly importance value contributed by Spartina alterniflora (SPAL), between 18 and 25\% by Spartina patens (SPPA) and about $10 \%$ by Distichlis spicata (DISP) in most years except 2006. A small percentage included Salicornia maritima (SAMA), Symphyotrichum tenuifolium (SYTE), and Limonium carolinianum (LICA). This pattern was consistent throughout the entire monitoring period at JoCo. At Elders East, the primary target species, Spartina alterniflora, dominated the importance value, ranging from 76 to $100 \%$ for all monitoring years. Salicornia depress (old name=maritima) does appear in the plots in 2007 and accounts for $24 \%$ of the importance value in 2008 before dropping to a lower importance value in 2009 through 2012. Salicornia depressa usually grows intermittently among high marsh vegetation and is very tolerant of high salinities (Silberhorn 1982). It is often found in salt panne areas and is not usually a large component of salt marshes along the U.S. Atlantic Coast, consistent with observations at JoCo Marsh.

\subsubsection{Percent Cover}

Percent cover was calculated for each plot-sampling event from point intercept data. For each intercepting point at which vegetation occurred, the species was identified and condition (Live / Dead) was noted. Quantity and features of nonvegetated points were also noted. Species point intercept counts (Cs) were standardized by total counts $\left(\mathrm{C}_{\mathrm{T}}\right)$ to calculate a percent cover of each species $\left(\mathrm{P}_{\mathrm{S}}\right)$.

$$
\begin{gathered}
C_{T}=\sum_{i=1}^{n} C_{S_{i}} \\
P_{S}=\frac{C_{S}}{C_{T}}
\end{gathered}
$$

Where $n=$ Total number of species 
Figure 8. Importance value of plant species at Elders East and JoCo Marsh.

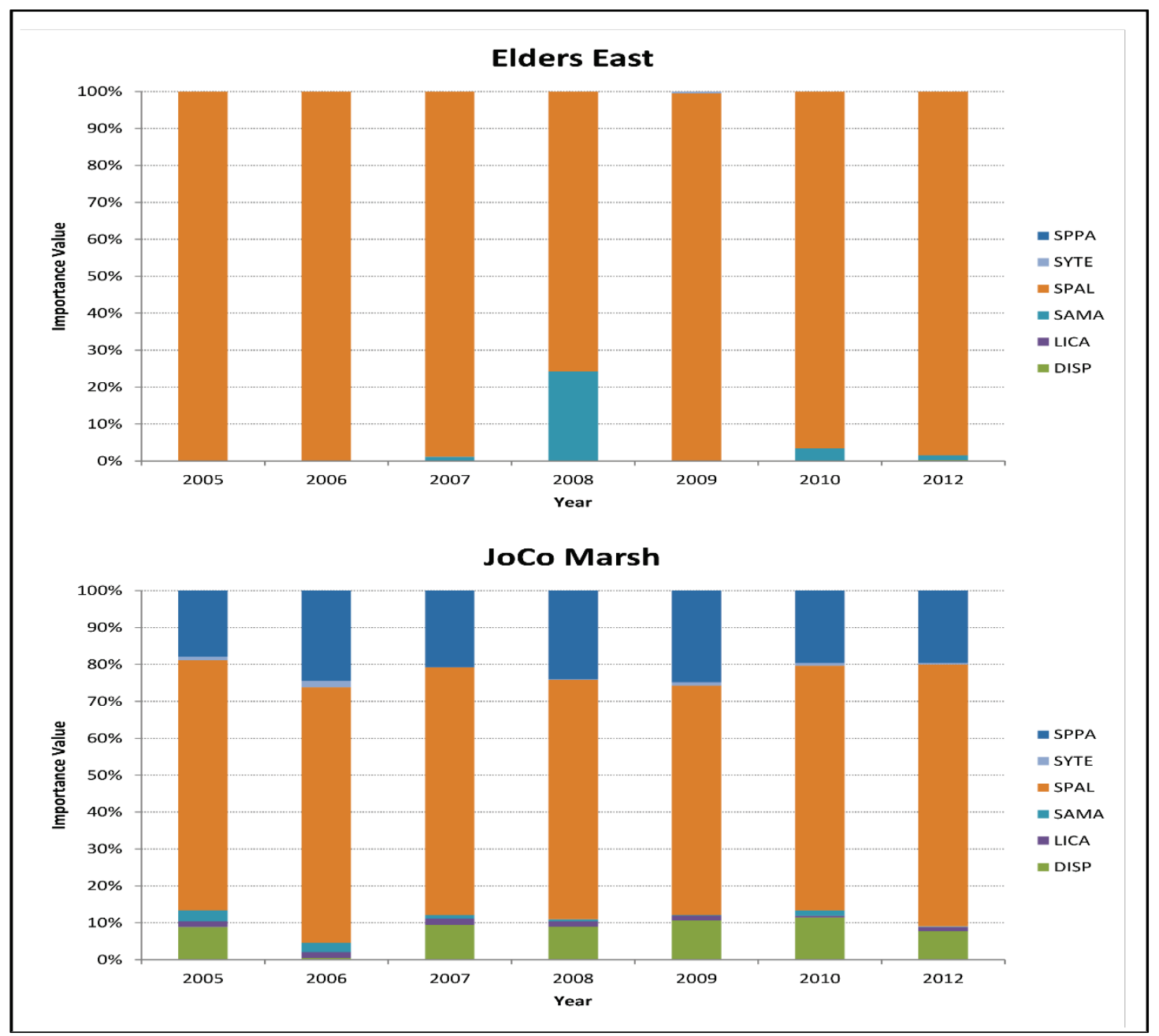

The data for JoCo Marsh indicated a relatively stable plant coverage condition of between 50 and 70\% from 2005 to 2012 (Figure 9). At Elders East, a steady increase in percent cover was observed from the prerestoration monitoring through the initial planting in 2006-2007 to a peak in 2008 at $71 \%$ coverage before dropping and then plateauing between approximately 40 and $50 \%$ for the remainder of the study period, or approximately $10 \%$ below the reference marsh during the same period (2009 to 2012). Total vegetative percent cover was significantly different $(p<0.05)$ between Elders East and JoCo Marsh during each year of the monitoring up to and including 2009, after which point no significant difference was detected (Appendix A; Table A-1). 
Figure 9. Growth measurements at Elders East and JoCo Marsh.

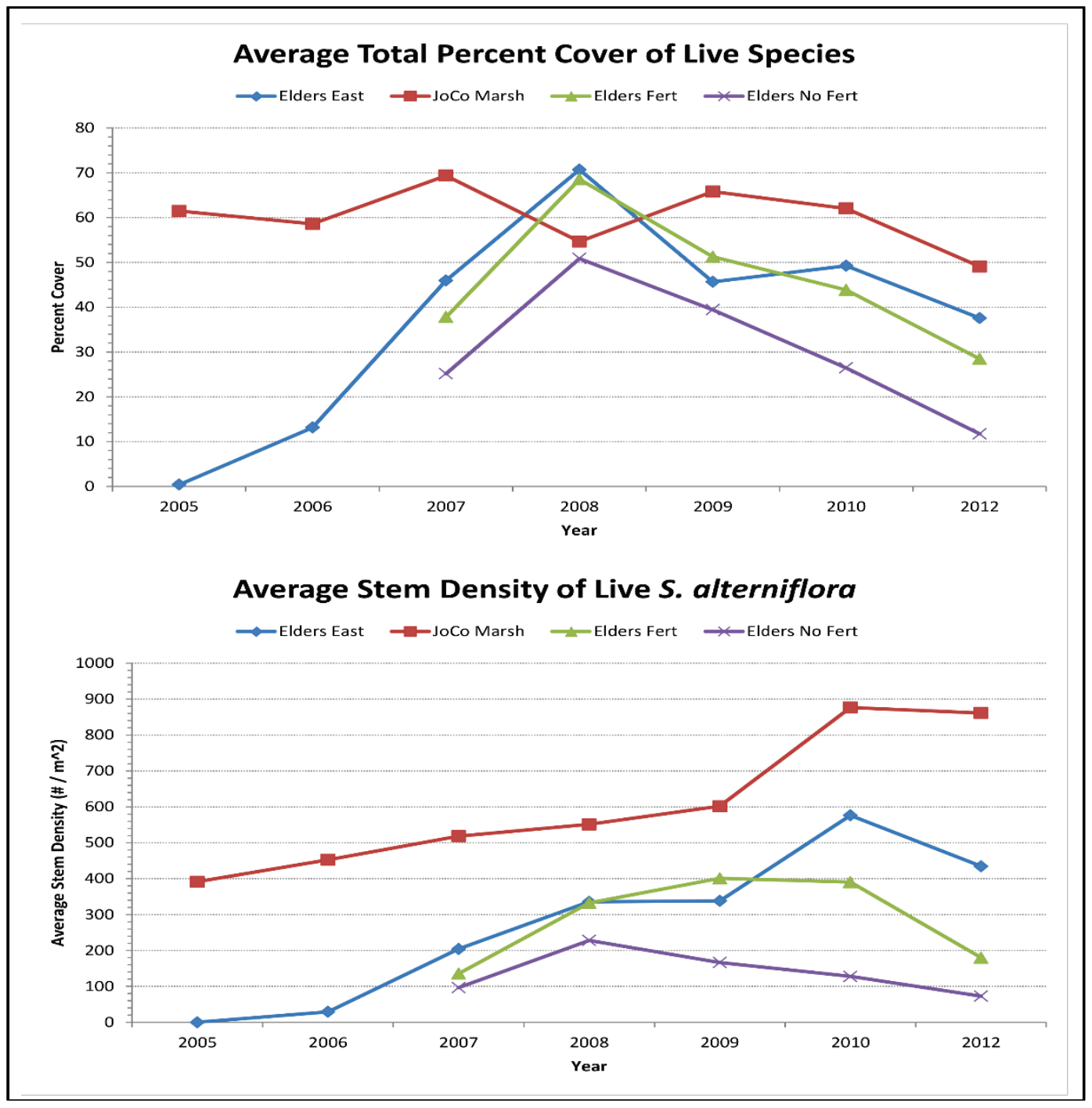

Similarly, the Elders Fertilizer site reached a peak of $69 \%$ coverage of live species in 2008 before decreasing steadily to a low of $28 \%$ coverage in 2012. The Elders No Fertilizer site followed a comparable trend but with approximately $10-20 \%$ less plant cover in each year, reaching a peak of $51 \%$ cover in 2008 before decreasing steadily to a low of $12 \%$ in 2012 (Figure 9). Total vegetative percent cover was significantly different $(p<0.05)$ between the Fertilizer and No Fertilizer treatment sites from 2007 through 2009; however, no significant difference was detected during the 2010 and 2012 monitoring years (Appendix A; Table A-1). 


\subsubsection{Stem Density and Condition (stem counts)}

Stem density was calculated from stem count data for each plot sampling event. Species were identified and condition (Live / Dead) was noted for each stem in one quadrant of each $1 \mathrm{~m}^{2}$ vegetation plot. Species stem counts $\left(\mathrm{Cs}_{\mathrm{s}}\right)$ were then standardized to the total area of each monitoring plot $\left(1 \mathrm{~m}^{2}\right)$ to return a stem density for each species (Ds).

$$
D_{S}=\frac{C_{S} \times 4}{1 m^{2}}
$$

Both JoCo Marsh and Elders East showed steady overall growth based on average stem count density of Spartina alterniflora over the course of the study period (Figure 9). The reference marsh started at an average density of approximately 400 stems $/ \mathrm{m}^{2}$ during the preconstruction monitoring in 2005 and increased steadily to $600 \mathrm{stems} / \mathrm{m}^{2}$ in 2009 before peaking above $860 \mathrm{stems} / \mathrm{m}^{2}$ in both 2010 and 2012. Elders East, in comparison, increased steadily during the construction and postrestoration period to a peak at $576 \mathrm{stems} / \mathrm{m}^{2}$ in 2010. The No Fertilizer and Fertilizer treatments at Elders East followed similar trajectories, increasing from low densities of Spartina alterniflora of less than $200 \mathrm{stems} / \mathrm{m}^{2}$ in 2007 to peaks of $228 \mathrm{stems} / \mathrm{m}^{2}$ and 400 stems $/ \mathrm{m}^{2}$ in 2008 and 2009, respectively (Figure 9).

Total stem count density for all live vegetation species ranged between 1,740 and 2,872 stems $/ \mathrm{m}^{2}$ on average at JoCo Marsh (Figure 9). Stem count density was highest from 2007 to 2010 at the reference site and lowest in 2005 and 2012. By comparison, total stem count density for all live vegetation at Elders East ranged from a low of $48 \mathrm{stems} / \mathrm{m}^{2}$ in 2006 to a high of $968 \mathrm{stems} / \mathrm{m}^{2}$ in 2010 . Total stem count density was significantly different $(p<0.05)$ between Elders East and JoCo Marsh during each year of the monitoring except for 2012 ( $p=0.098)$ when no significant difference was detected (Appendix A; Table A-2). Stem density was significantly different $(p<0.05)$ between the Fertilizer and No Fertilizer treatment sites from 2007 through 2010; however, no significant difference ( $p=0.612$ ) was detected in 2012 (Appendix A; Table A-2).

Typically, standing dead plants accounted for between 10 and $25 \%$ of the total stem count density at both JoCo and Elders East (Figure 10). 
Figure 10. Stem survival at Elders East and JoCo Marsh.

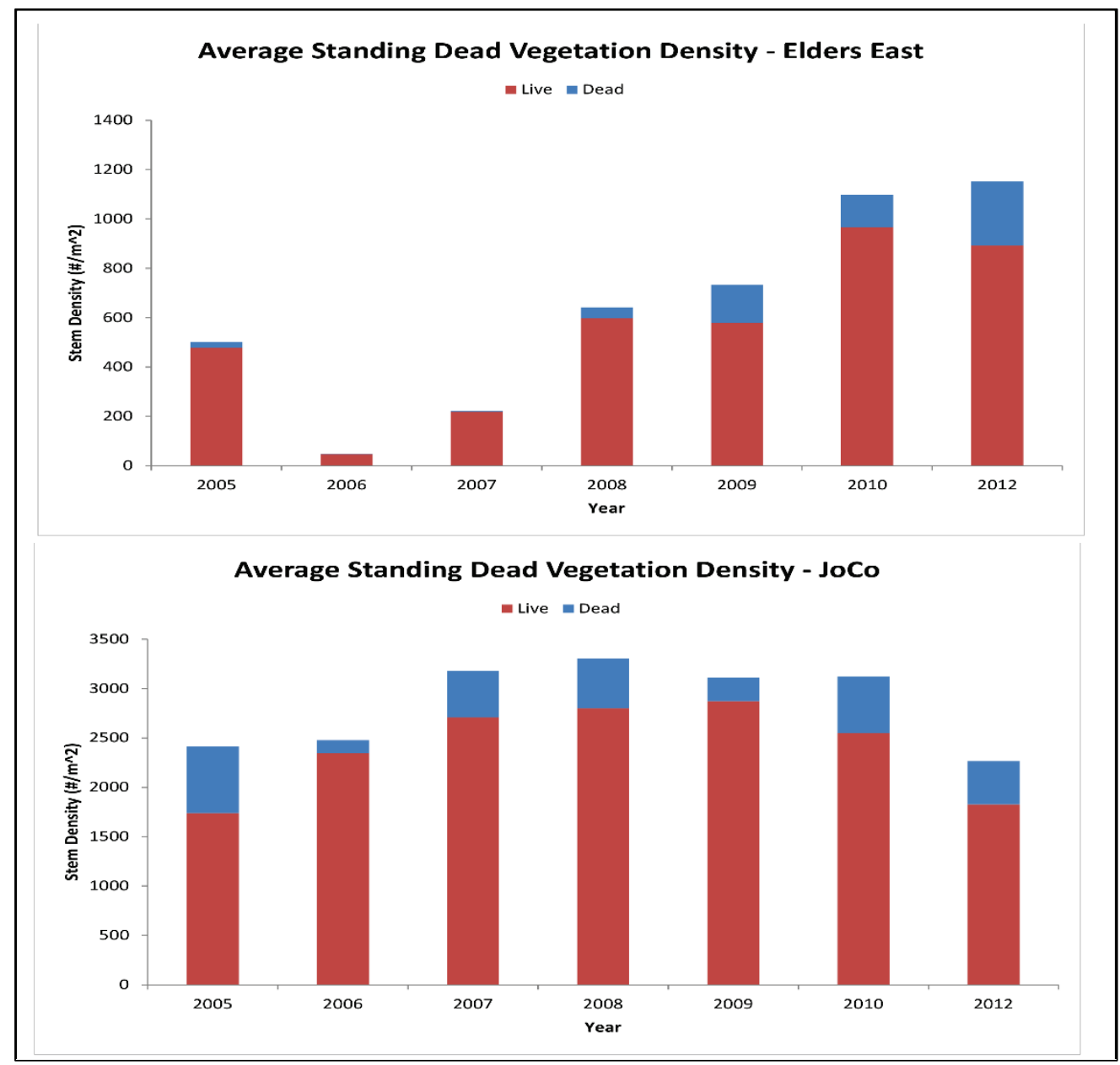

\subsubsection{Height of Spartina alterniflora}

The height to the highest plant part of the three tallest Spartina alterniflora plants were measured in each $1 \mathrm{~m}^{2}$ quadrat during each plot sampling event. Figure 11 plots the average height to leaf for Spartina alterniflora at both JoCo and Elders East during the monitoring period. JoCo Marsh had a consistent average highest height of between 72 and $93 \mathrm{~cm}$ in all years. At Elders East, the average highest stem height when first planted measured $27 \mathrm{~cm}$ and very steadily climbed to a peak of $124 \mathrm{~cm}$ in 2009 or about $40 \mathrm{~cm}$ higher on average than that of JoCo Marsh in that year. After 2009, average highest plant height at Elders East leveled off at just below $100 \mathrm{~cm}$ but remained slightly higher than at JoCo Marsh. Stem height between Elders East and JoCo Marsh was significantly different $(p<0.05)$ in all monitoring years (Appendix A; Table A-3). 
Figure 11. Average height to leaf of live Spartina alterniflora at Elders East and JoCo Marsh.

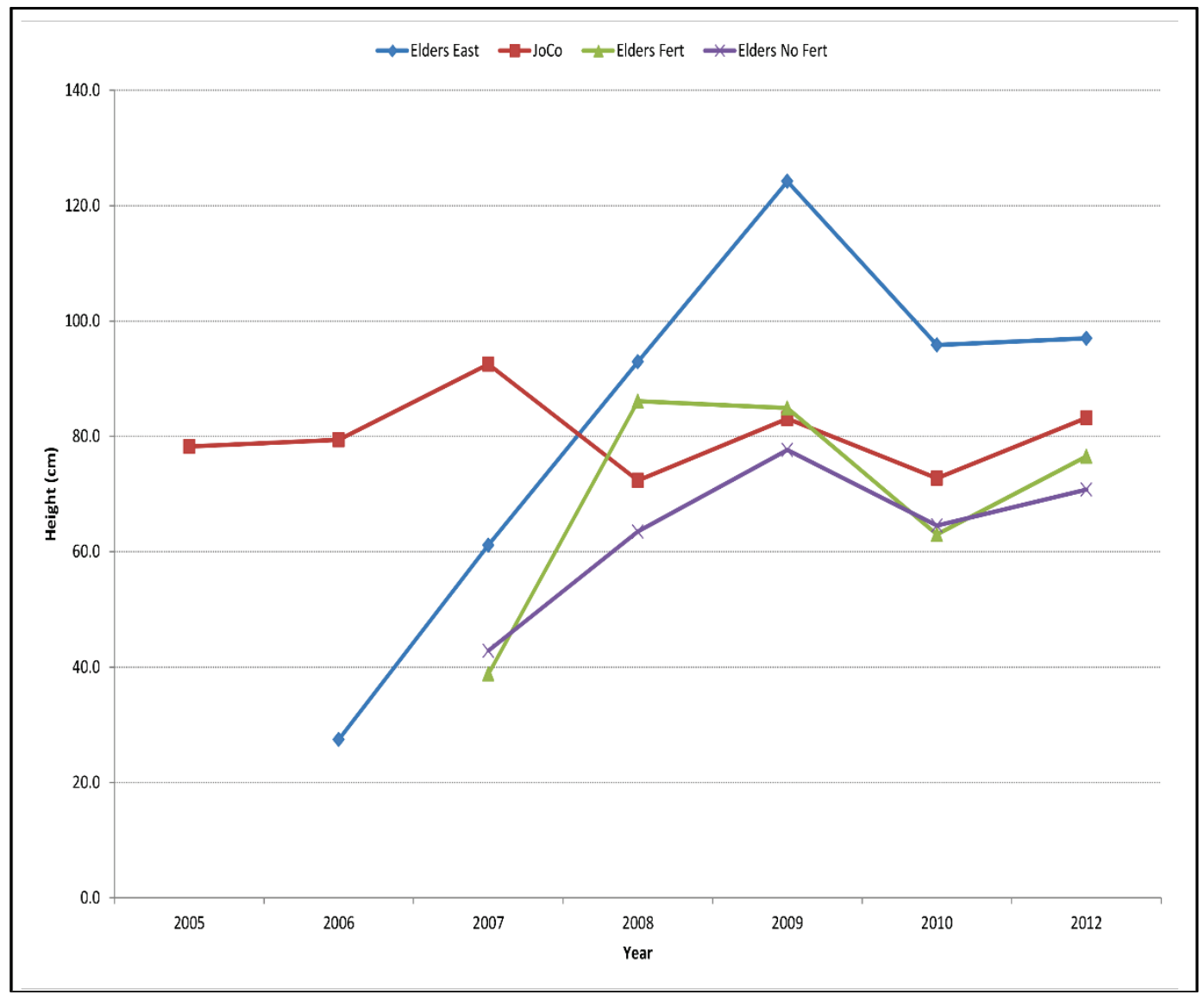

The Elders East Fertilizer and No Fertilizer treatments followed similar trajectories, increasing from low heights of about $40 \mathrm{~cm}$ in 2007 to a peak of $86 \mathrm{~cm}$ for the Fertilizer treatment in 2008 and a peak of $78 \mathrm{~cm}$ for the No Fertilizer treatment in 2009 (Figure 11). Stem heights of Spartina alterniflora were significantly different $(p<0.05)$ between the Fertilizer and No Fertilizer treatments in 2007 and then again in 2010 and 2012; no significant difference in stem height between these treatments was detected in 2008 and 2009 ( $p=0.804$ and $p=0.673$ respectively) (Appendix A; Table A-3).

\subsubsection{Vegetation Diversity Indices}

The following measures of species diversity were used to evaluate the vegetation communities at the Elders East restoration treatment and reference marsh sites.

Richness (S) equals the number of different or unique plant species in a sample. 
Number $(N)$ equals the total number of plants summed over all the species in a sample.

Margalef's Diversity Index ( $\left.\boldsymbol{D}_{\mathrm{mg}}\right)$ is a relatively simple index that uses a combination of $\mathbf{S}$ and $\mathbf{N}$. The formula is:

$$
D_{m g}=(S-1) / \ln N
$$

Heterogeneity, or Simpson's Index (C), reflects dominance because it weights the most abundant species more heavily than the rare species. Its formula is:

$$
C=\sum_{i=1}^{S}\left(p_{i}\right)^{2}
$$

Where $\mathbf{S}$ is the total number of species in the sample and $\mathbf{p}_{\mathbf{i}}$ is the proportion of all individuals in the sample that belong to species $\mathbf{i}$.

At Elders East, species richness increased steadily each year during the monitoring from three species during prerestoration and restoration construction (2005 to 2007) to a high of nine species in 2012 (Table 4). This trend was repeated for both Margalef's Diversity Index (0.25 in 2005 to 0.90 in 2012) and Simpson's Heterogeneity (0.06 in 2005 to 0.65 in 2012) providing evidence that Elders East was maturing steadily over the course of the monitoring program. By comparison, JoCo Marsh remained remarkably consistent from 2005 to 2012 for each of these diversity measures, varying between 8 and 10 species, with a diversity between 0.74 and 1.01, and a heterogeneity between 0.54 and 0.71 (Table 4).

No clear vegetation diversity trends were apparent in the Fertilizer versus No Fertilizer treatments as species richness, diversity, and heterogeneity were generally comparable in 2007 and 2008. In 2009, the Fertilizer site had slightly more species and higher diversity but by 2010 and 2012 those indices were reversed with the No Fertilizer site in 2012, showing a peak of seven species and the highest Margalef's Diversity of 0.78. From 2007 to 2009, the No Fertilizer treatment had greater heterogeneity, but from 2010 to 2012 that pattern was reversed, with the Fertilizer treatment presenting greater heterogeneity despite having lower diversity and richness (Table 4). 
Table 4. Stem count live vegetation diversity indices, Elders Island monitoring sites, 2005 - 2012.

\begin{tabular}{|c|c|c|c|c|c|c|}
\hline Site & Year & $\begin{array}{c}\text { Plots } \\
\text { Measured }\end{array}$ & Species Richness & $\begin{array}{c}\text { Average } \\
\text { \# Species / Plot }\end{array}$ & $\begin{array}{c}\text { Diversity } \\
\text { (Margalef) }\end{array}$ & $\begin{array}{l}\text { Heterogeneity } \\
\text { (Simpson) }\end{array}$ \\
\hline \multirow{7}{*}{ Elders East } & 2005 & 26 & 3 & 1.35 & 0.25 & 0.06 \\
\hline & 2006 & 32 & 3 & 1.16 & 0.34 & 0.47 \\
\hline & 2007 & 32 & 3 & 1.09 & 0.27 & 0.12 \\
\hline & 2008 & 32 & 4 & 1.88 & 0.36 & 0.53 \\
\hline & 2009 & 32 & 7 & 3.22 & 0.71 & 0.59 \\
\hline & 2010 & 32 & 7 & 3.31 & 0.67 & 0.59 \\
\hline & 2012 & 32 & 9 & 3.22 & 0.90 & 0.65 \\
\hline \multirow{7}{*}{ JoCo } & 2005 & 28 & 8 & 2.96 & 0.74 & 0.71 \\
\hline & 2006 & 28 & 10 & 3.96 & 0.93 & 0.54 \\
\hline & 2007 & 28 & 10 & 3.64 & 0.91 & 0.58 \\
\hline & 2008 & 28 & 11 & 3.82 & 1.01 & 0.59 \\
\hline & 2009 & 28 & 11 & 3.89 & 1.01 & 0.62 \\
\hline & 2010 & 28 & 10 & 3.79 & 0.92 & 0.64 \\
\hline & 2012 & 28 & 10 & 3.43 & 0.96 & 0.67 \\
\hline \multirow{5}{*}{ Elders Fert } & 2007 & 33 & 2 & 1.27 & 0.14 & 0.10 \\
\hline & 2008 & 33 & 3 & 1.27 & 0.25 & 0.08 \\
\hline & 2009 & 33 & 6 & 2.42 & 0.58 & 0.52 \\
\hline & 2010 & 33 & 6 & 2.48 & 0.55 & 0.64 \\
\hline & 2012 & 33 & 5 & 1.85 & 0.47 & 0.63 \\
\hline \multirow{5}{*}{ Elders No Fert } & 2007 & 31 & 2 & 1.16 & 0.14 & 0.42 \\
\hline & 2008 & 30 & 3 & 1.23 & 0.26 & 0.27 \\
\hline & 2009 & 30 & 4 & 1.53 & 0.38 & 0.61 \\
\hline & 2010 & 30 & 7 & 1.70 & 0.74 & 0.53 \\
\hline & 2012 & 30 & 7 & 1.50 & 0.78 & 0.54 \\
\hline
\end{tabular}

\subsubsection{Biomass}

\subsubsection{Aboveground Biomass}

Aboveground biomass samples were taken from biomass plot offset from each permanent vegetation plot for each sampling event. Plot sizes were $15 \mathrm{~cm}^{2}$ in 2005 and 2006 and $25 \mathrm{~cm}^{2}$ in all subsequent years. Samples were oven-dried and weighed. Sample weight (Ws) was divided by the sample area (As) to yield areal biomass density (Bs) expressed as $\mathrm{g} / \mathrm{m}^{2}$.

$$
B_{S}=\frac{W_{S}}{A_{S}}
$$

Figure 12 compares data from JoCo and Elders East for both aboveground and belowground biomass. JoCo maintained an average yearly aboveground biomass of between 700 and $1,000 \mathrm{~g} / \mathrm{m}^{2}$, indicating a relatively stable pattern. The biomass data from the restoration marsh showed much higher yearly variation and indicated a less mature ecosystem overall. Immediately after the initial planting of the marsh, aboveground biomass remained low until 2008 despite reasonable percent cover and stem counts in the first year and some significant belowground biomass in 2005. Planted as 2-inch 
plugs, the individual plants had very low biomass. After the first year of establishment at Elders East, aboveground biomass increased dramatically to approximate reference conditions (between 800 and $1,200 \mathrm{~g} / \mathrm{m}^{2}$ ) from 2008 to 2010. Both sites showed some decline in aboveground biomass between 2010 and 2012. Vegetative aboveground biomass was significantly different $(p<0.05)$ between Elders East and JoCo Marsh from 2005 through 2008; no significant difference was detected from 2009 through the end of the monitoring period in 2012 (Appendix A; Table A-4).

Figure 12. Ratio of average above ground biomass to below ground biomass at Elders East and JoCo Marsh.

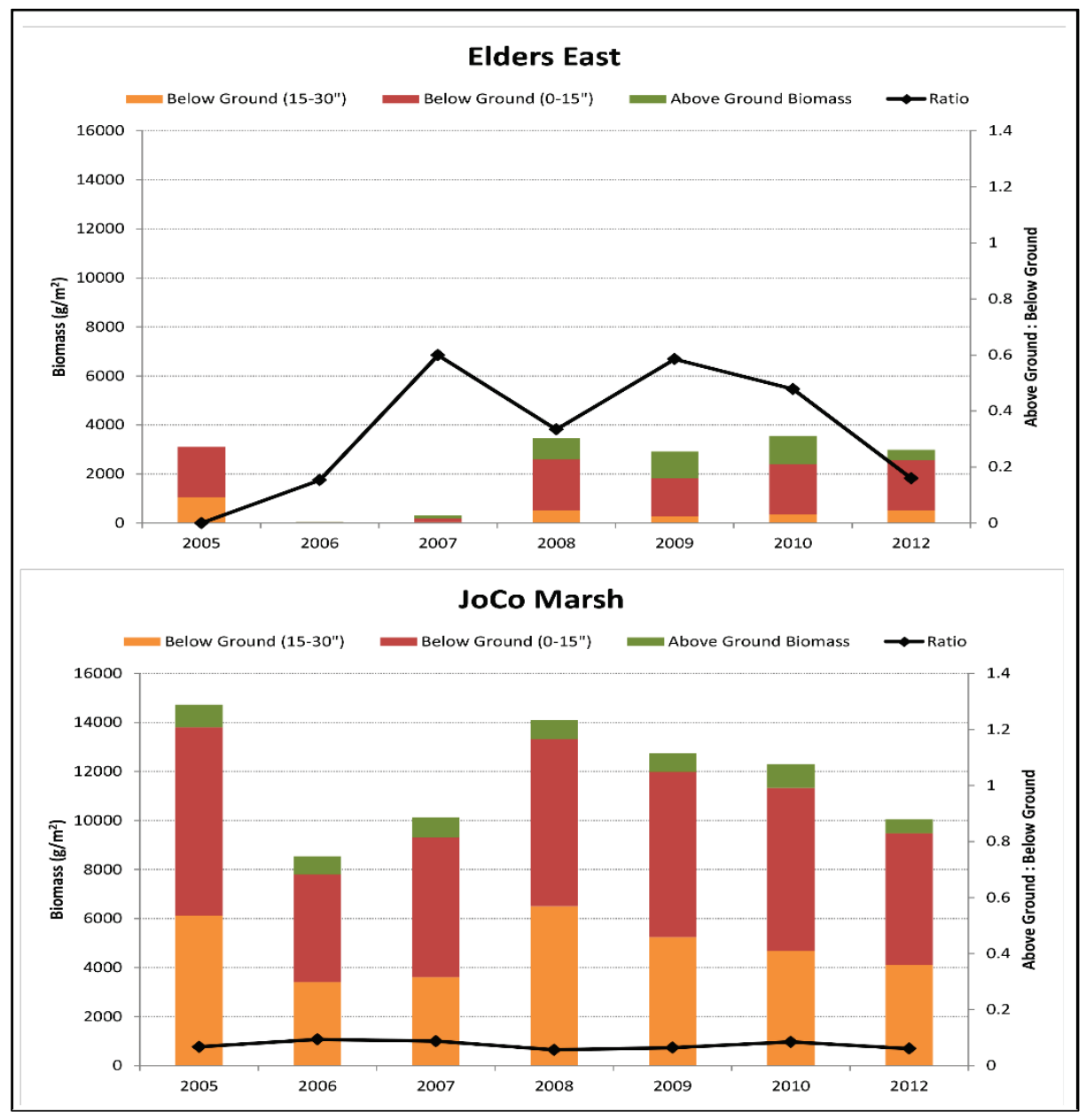

\subsubsection{Belowground Biomass}

Belowground biomass samples were taken from a separate offset location using a 6-inch diameter core to a depth of $30 \mathrm{~cm}$. Belowground biomass samples were split into two discrete samples based on depth: $0-15 \mathrm{~cm}$ and $15-30 \mathrm{~cm}$. All macroorganic material was removed from each belowground 
biomass sample, ovendried, and weighed. Sample weight ( $\left.\mathrm{W}_{\mathrm{s}}\right)$ was divided by sample area (As) to yield areal biomass density (Bs) expressed as $\mathrm{g} / \mathrm{m}^{2}$.

$$
B_{S}=\frac{W_{S}}{A_{S}}
$$

Values for Elders East remained around tenfold lower than those from JoCo Marsh for belowground biomass (Figure 12). Yearly belowground biomass at JoCo Marsh consistently ranged between 4,300 and $7,700 \mathrm{~g} / \mathrm{m}^{2}$ at the $\mathrm{o}-$ $15 \mathrm{~cm}$ interval and between 3,400 and $6,500 \mathrm{~g} / \mathrm{m}^{2}$ at the deeper $15-30 \mathrm{~cm}$ interval, indicating a relatively stable vegetative root system (Figure 12). By comparison, belowground biomass at Elders East was approximately 1,000 and $2,000 \mathrm{~g} / \mathrm{m}^{2}$ on average at the $15-30$ and $0-15 \mathrm{~cm}$ intervals, respectively, during the pre-construction monitoring, but declined to less than $200 \mathrm{~g} / \mathrm{m}^{2}$ total belowground biomass during construction (2006 and 2007) before consistently reaching approximately $2,500 \mathrm{~g} / \mathrm{m}^{2}$ total belowground biomass on average for the remainder of the monitoring period. In general, the deeper $15-30 \mathrm{~cm}$ interval accounted for approximately $20-25 \%$ of the total belowground biomass at Elders East from 2008 to 2012. During this same period of marsh establishment, total belowground biomass at Elder East was approximately one fourth that of the JoCo reference marsh on average (Figure 12).

Vegetative belowground biomass for the 0-15 and 15-30 $\mathrm{cm}$ depths were significantly higher $(p<0.05)$ at JoCo Marsh when compared to Elders East for each monitoring year (Appendix A; Table A-5 and A-6).

\subsubsection{Biomass Ratios}

Ratios at the JoCo reference marsh range between 0.06 and 0.10 throughout the monitoring period with belowground biomass consistently accounting for more than $90 \%$ of the measured biomass on average, indicative of a well-established marsh (Figure 12). For Elders East the data indicated high yearly variation as changes occurred in relatively small increments for both biomass measures, particularly during the first three years of monitoring (2005-2007). Because disturbances to the surface vegetation will disproportionally reduce aboveground biomass and shift the ratio, this variation is not unexpected in a restoration marsh. During the next four years (2008-2012), the biomass ratio at Elders East fluctuated around 1:2 in favor of belowground biomass before decreasing in 2012 to 
approximately 1:5, a ratio more typical of those found at JoCo Marsh (Figure 12).

\subsubsection{Biomass at Fertilizer versus No Fertilizer Treatments}

After the initial plantings in 2007, the Fertilizer site on average produced slightly higher above- and below-ground biomasses in 2008 and 2009. In 2010, the No Fertilizer treatment had comparable aboveground biomass to the Fertilizer treatment, but had more than twice the average belowground biomass in the deeper 15-30 inch layer (Figure 13). However, by 2012, the Fertilizer treatment again showed higher aboveground and belowground biomass values in comparison to the No Fertilizer site, although both treatments experienced biomass increases from the initial plantings in 2007. After the initial planting in 2007, both treatment sites consistently had an approximate 1:2 ratio (0.5) for aboveground to belowground biomass (Figure 13). After the initial planting in 2007, no significant difference ( $p>0.05$ ) between the Fertilizer and No Fertilizer sites was observed for aboveground biomass from 2008 to 2012 (Appendix A; Table A-4). No significant difference $(p>0.05)$ between the Fertilizer and No Fertilizer sites was observed for belowground biomass during each year of the monitoring program (Appendix A; Table A-5 and A-6).

\subsection{Benthic Macroinvertebrates}

The benthic community within Jamaica Bay consists of a wide variety of invertebrates that live burrowed into or in contact with the bottom, such as worms, mollusks, and amphipods. Benthic invertebrate communities are an essential part of the estuarine food web as they cycle nutrients from the sediment and water column to higher trophic levels. The distribution and abundance of benthic invertebrates may be influenced by a wide variety of physical parameters, such as substrate composition, water temperature, dissolved oxygen, $\mathrm{pH}$, salinity, and hydrodynamics, as well as by disturbance and pollution (Levinton 1982, Cristini 1991, Watson and Barnes 2004). Moreover, benthic organisms are often good indicators of local environmental conditions and anthropogenic disturbance since they live in and feed on the sediment and have limited mobility, rendering them susceptible to exposure to pollutants or disturbance (Dauer 1993). 
Figure 13. Average biomass comparison between fertilizer treatment and nonfertilizer treatment at Elders East.

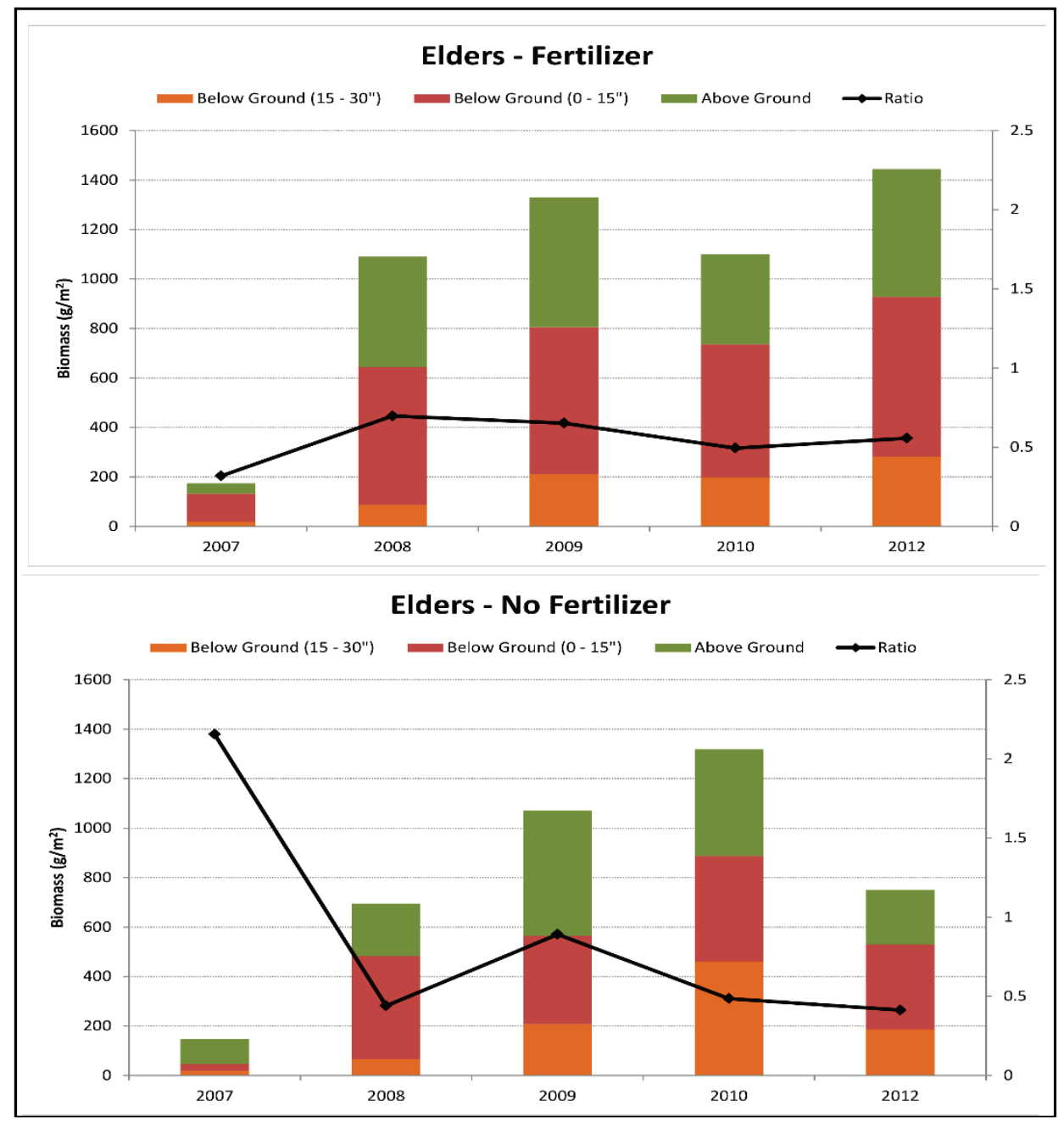

Benthic sampling at the Elders East restoration and JoCo Marsh was accomplished using a 6-inch diameter, $30 \mathrm{~cm}$ depth sediment core taken from approximately half of the permanent vegetation plots for each site. A total of between 13 and 16 benthic samples were collected at each year at each site (Table 5). Benthic organisms were removed, identified, and counted using standard methods described by New (1998) and USACENYD (2007). Identifications were made to the lowest practical identification level.

\subsubsection{Community Composition}

The most commonly collected benthic macroinvertebrates were: horseshoe crab (Limulus polyphemus) - an arthropod that composed 51.5\% of the total number of macroinvertebrates collected; segmented aquatic worms 
of the class Oligochaeta (16.0\% of the total); the bivalve mollusk ribbed mussel (Geukensia demissa) at 11.8\%; and the gastropod eastern mudsnail (Nassarius obsoletus) at 7.2\% (calculated from date in Table 5).

Of note, horseshoe crabs were collected consistently in most years at the Elders East restoration locations beginning in 2008, but were not collected during the monitoring at JoCo Marsh. The majority of horseshoe crabs (78\%) were collected at the Elders Fertilizer location. The high densities of horseshoe crabs were predominantly due to extremely high counts within a few plots; $34.5 \%$ of the counted horseshoe crabs were eggs; $12.5 \%$ were larvae; and 53.0\% were juveniles. By comparison, Oligochaetes and ribbed mussels were collected across each treatment area in most years from 2008 onward, and eastern mudsnails were collected every year at each treatment site as well as at the reference location, but were generally much more common at the Elders East locations (Table 5).

\subsubsection{Benthic Density}

Sample count (Cs) was divided by sample area (As) to yield areal benthic density (Bs) expressed as number per $\mathrm{m}^{2}$.

$$
B_{S}=\frac{C_{S}}{A_{S}}
$$

Relatively high average benthic community densities ( $>300$ organisms per $\mathrm{m}^{2}$ on average) were present at the Elders East restoration locations from 2008 to 2012, and were higher than densities at the JoCo reference location in all years except 2006 and 2007, which corresponded to the years of construction at Elders East (Table 6). Prior to the construction, benthic density in 2005 was comparable between Elders East and JoCo (94 and 72 organisms per $\mathrm{m}^{2}$, respectively), but post-construction samples at the Elders East location contained up to six times higher average plot densities (e.g., 2010). Benthic macroinvertebrate density was significantly higher ( $p<0.05)$ at Elders East than at JoCo Marsh in 2005, 2006, 2008, and 2010 (Appendix A; Table A-7). 
Table 5. Count of benthic organisms collected at Elders Island monitoring sites, 2005-2012.

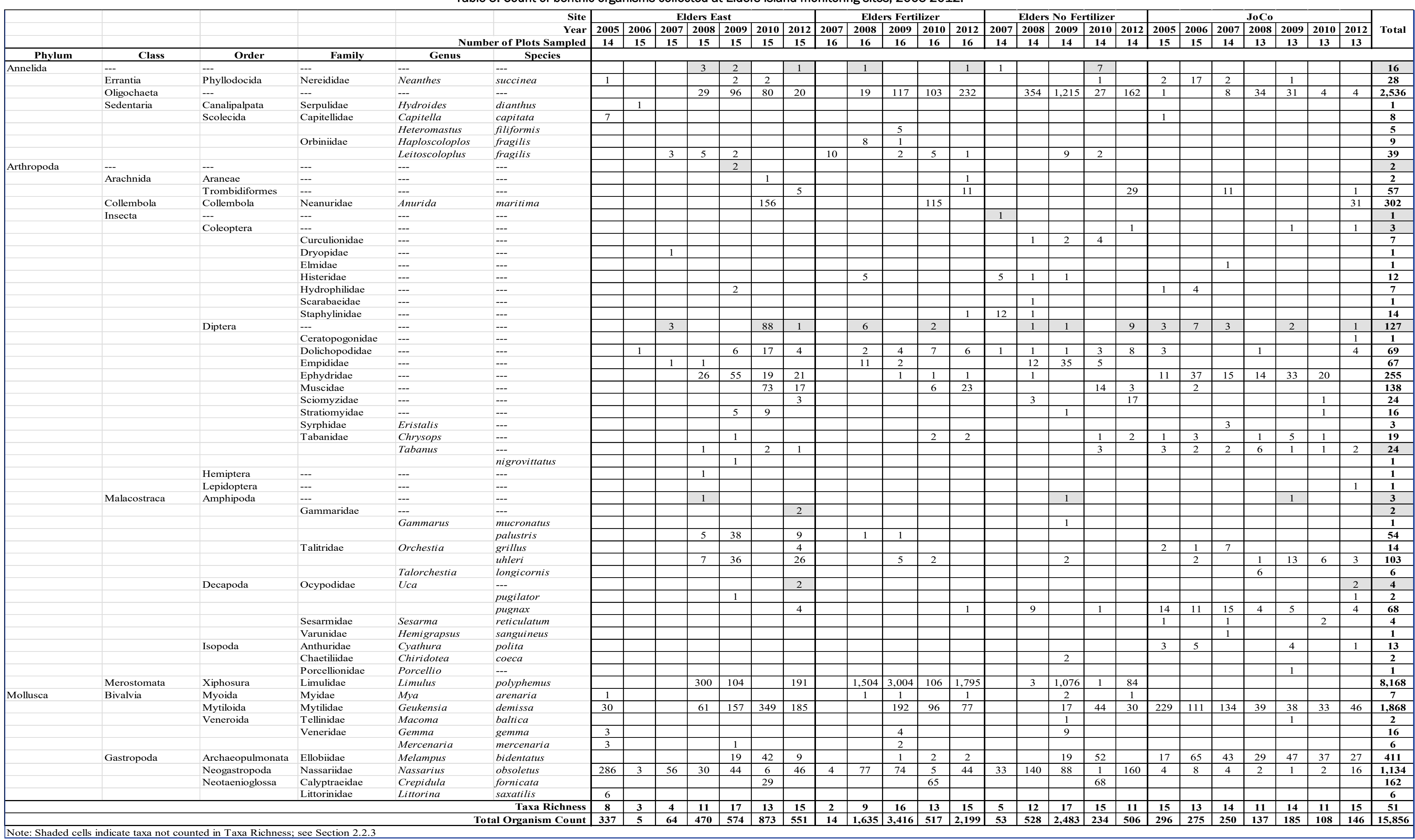


Table 6. Benthic Community Indices: True Taxa Richness, Total Organism Count, Average Density by Sample Plot (no. organisms / $\mathrm{m}^{2}$ ), Shannon-Weiner's Diversity $\left(\mathrm{H}^{\prime}\right)$, and Pielou's Evenness $\left(\mathrm{J}^{\prime}\right)$; Elders Island Monitoring Sites, 2005 - 2012.

\begin{tabular}{|c|c|c|c|c|c|c|}
\hline Site & Year & Taxa Richness & Total Count & Average Density & $\mathrm{H}^{\prime}$ & $J^{\prime}$ \\
\hline \multirow{7}{*}{ Elders East } & 2005 & 8 & 337 & 94 & 0.63 & 0.30 \\
\hline & 2006 & 3 & 5 & 1 & 0.95 & 0.86 \\
\hline & 2007 & 4 & 64 & 16 & 0.53 & 0.38 \\
\hline & 2008 & 11 & 470 & 115 & 1.30 & 0.54 \\
\hline & 2009 & 17 & 574 & 140 & 2.08 & 0.74 \\
\hline & 2010 & 13 & 873 & 213 & 1.87 & 0.73 \\
\hline & 2012 & 15 & 551 & 134 & 1.83 & 0.67 \\
\hline \multirow{5}{*}{ Elders Fertilizer } & 2007 & 2 & 14 & 3 & 0.60 & 0.86 \\
\hline & 2008 & 9 & 1,635 & 350 & 0.39 & 0.18 \\
\hline & 2009 & 16 & 3,416 & 732 & 0.53 & 0.19 \\
\hline & 2010 & 13 & 517 & 111 & 1.85 & 0.72 \\
\hline & 2012 & 15 & 2,199 & 471 & 0.73 & 0.27 \\
\hline \multirow{5}{*}{ Elders No Fertilizer } & 2007 & 5 & 53 & 15 & 1.08 & 0.67 \\
\hline & 2008 & 12 & 528 & 148 & 0.92 & 0.37 \\
\hline & 2009 & 17 & 2,483 & 694 & 1.05 & 0.37 \\
\hline & 2010 & 15 & 234 & 65 & 1.95 & 0.72 \\
\hline & 2012 & 11 & 506 & 142 & 1.69 & 0.70 \\
\hline \multirow{7}{*}{ JoCo } & 2005 & 15 & 296 & 72 & 1.04 & 0.38 \\
\hline & 2006 & 13 & 275 & 67 & 1.79 & 0.70 \\
\hline & 2007 & 14 & 250 & 70 & 1.64 & 0.62 \\
\hline & 2008 & 11 & 137 & 44 & 1.81 & 0.76 \\
\hline & 2009 & 14 & 185 & 60 & 1.99 & 0.75 \\
\hline & 2010 & 11 & 108 & 35 & 1.65 & 0.69 \\
\hline & 2012 & 15 & 146 & 47 & 1.98 & 0.73 \\
\hline
\end{tabular}

From 2008 to 2012, the Elders Fertilizer location had higher total benthic community density on average than the Elders No Fertilizer location (Table 6). However, no significant difference ( $p>0.05$ ) in benthic density between the Fertilizer and No Fertilizer sites was detected in any monitoring year (Appendix A; Table A-7).

Elders East tended to have a higher percentage of mollusks (60.0 to 97.6\%) from 2005 to 2007, whereas arthropods tended to dominate the collections (41.8 to 72.8\%) from 2008 to 2012 (Table 7). However, densities were generally very low at Elders East prior to and during the construction (2005 to 2007). Mollusks comprised the majority of the collections based on density in all years at JoCo, ranging from $47.0 \%$ (2009) to $84.5 \%$ (2005) of 
the yearly collections by phylum. Excluding 2007 (which had very low density), the Elders Fertilizer site was dominated in all years by arthropods (46.6 to 93.5\%), while the Elders No Fertilizer site was dominated by annelids in 2008 (67.0\%) and 2009 (49.3\%), and by mollusks in 2007 (62.3\%), $2010(70.5 \%)$, and $2012(37.7 \%)$.

Table 7. Average density by sampling plot (no. organisms $/ \mathrm{m}^{2}$ ) and percentage of total average density by phylum; benthic organisms at Elders Island monitoring sites, 2005 - 2012.

\begin{tabular}{|c|c|c|c|c|c|c|c|}
\hline \multirow[b]{2}{*}{ Site } & \multirow[b]{2}{*}{ Year } & \multicolumn{2}{|c|}{ Annelida } & \multicolumn{2}{|c|}{ Arthropoda } & \multicolumn{2}{|c|}{ Mollusca } \\
\hline & & Density & $\%$ & Density & $\%$ & Density & $\%$ \\
\hline \multirow{7}{*}{ Elders East } & 2005 & 2 & $2.4 \%$ & 0 & $0.0 \%$ & 92 & $97.6 \%$ \\
\hline & 2006 & $<1$ & $20.0 \%$ & $<1$ & $20.0 \%$ & 1 & $60.0 \%$ \\
\hline & 2007 & 1 & $4.7 \%$ & 1 & $7.8 \%$ & 14 & $87.5 \%$ \\
\hline & 2008 & 9 & $7.9 \%$ & 83 & $72.8 \%$ & 22 & $19.4 \%$ \\
\hline & 2009 & 25 & $17.8 \%$ & 61 & $43.7 \%$ & 54 & $38.5 \%$ \\
\hline & 2010 & 20 & $9.4 \%$ & 89 & $41.8 \%$ & 104 & $48.8 \%$ \\
\hline & 2012 & 5 & $3.8 \%$ & 71 & $52.6 \%$ & 58 & $43.6 \%$ \\
\hline \multirow{5}{*}{ Elders Fertilizer } & 2007 & 2 & $71.4 \%$ & 0 & $0.0 \%$ & $<1$ & $28.6 \%$ \\
\hline & 2008 & 6 & $1.7 \%$ & 327 & $93.5 \%$ & 17 & $4.8 \%$ \\
\hline & 2009 & 27 & $3.7 \%$ & 646 & $88.3 \%$ & 59 & $8.0 \%$ \\
\hline & 2010 & 23 & $20.9 \%$ & 52 & $46.6 \%$ & 36 & $32.5 \%$ \\
\hline & 2012 & 50 & $10.6 \%$ & 394 & $83.7 \%$ & 27 & $5.6 \%$ \\
\hline \multirow{5}{*}{ Elders No Fertilizer } & 2007 & $<1$ & $1.9 \%$ & 5 & $35.8 \%$ & 9 & $62.3 \%$ \\
\hline & 2008 & 99 & $67.0 \%$ & 10 & $6.4 \%$ & 39 & $26.5 \%$ \\
\hline & 2009 & 342 & $49.3 \%$ & 314 & $45.2 \%$ & 38 & $5.5 \%$ \\
\hline & 2010 & 10 & $15.8 \%$ & 9 & $13.7 \%$ & 46 & $70.5 \%$ \\
\hline & 2012 & 45 & $32.0 \%$ & 43 & $30.2 \%$ & 53 & $37.7 \%$ \\
\hline \multirow{7}{*}{ JoCo } & 2005 & 1 & $1.4 \%$ & 10 & $14.2 \%$ & 61 & $84.5 \%$ \\
\hline & 2006 & 4 & $6.2 \%$ & 18 & $26.9 \%$ & 45 & $66.9 \%$ \\
\hline & 2007 & 3 & $4.0 \%$ & 17 & $23.6 \%$ & 51 & $72.4 \%$ \\
\hline & 2008 & 11 & $24.8 \%$ & 11 & $24.1 \%$ & 23 & $51.1 \%$ \\
\hline & 2009 & 10 & $17.3 \%$ & 21 & $35.7 \%$ & 28 & $47.0 \%$ \\
\hline & 2010 & 1 & $3.7 \%$ & 10 & $29.6 \%$ & 23 & $66.7 \%$ \\
\hline & 2012 & 1 & $2.7 \%$ & 17 & $36.3 \%$ & 29 & $61.0 \%$ \\
\hline
\end{tabular}

The following biodiversity indices were also calculated to assess the benthic communities within the various Elders East treatment sites. 


\subsubsection{Taxa Richness}

Taxa richness is a measure of the total number of individual taxa collected at a site. In counting the number of taxa present, general taxonomic designations at the generic, familial, and higher taxonomic levels were excluded if there was at least one valid lower level designation for that group. For example, if the annelid polychaete Leitoscoloplos sp., Leitoscoloplos fragilis, and Leitoscoloplos robustus were all identified in one sample, then Leitoscoloplos sp. was not counted in the total number of taxa. The number of Leitoscoloplos taxa recorded in this example would be two.

The highest number of taxa (17) was collected at the Elders East and Elders Fertilizer locations in 2009 (Table 6). Higher taxa richness was found at the JoCo reference location in 2005, 2006, and 2007 compared to the restoration site locations, which had the five lowest yearly totals (all less than 9 taxa) in 2005-2007. The JoCo reference location consistently yielded between 11 and 15 taxa in all sampling years compared to the restoration sites, which trended towards higher taxa richness as the restoration matured. On average, the Elders No Fertilizer site had slightly higher taxa richness from 2007 to 2012 than did the Elders Fertilizer site (12 compared to 11, respectively). The Elders No Fertilizer location had higher taxa richness than the Elders Fertilizer site in all of the sampling years, except for 2012 (Table 6).

The majority of taxa collected were arthropods (typically between 50 and $70 \%$ of the collection at each treatment area each year), followed by mollusks (typically between 20 and $40 \%$ of the taxa collected), and annelids (typically less than $25 \%$ of the taxa collected) (Table 8 ). Based on yearly average, JoCo had a higher percentage of arthropod taxa (64.5\%) compared to Elders East (47.6\%), and a lower percentage of mollusks (23.9\% versus 32.3\%). Similarly, the Elders No Fertilizer site had a higher percentage of arthropod taxa (62.6\% on average) compared to the Elders Fertilizer site (41.4\%), and a lower percentage of mollusks (23.5\% versus $33.4 \%$ ). 
Table 8. Taxa richness and percentage of total taxa richness by phylum; benthic organisms at Elders Island monitoring sites, 2005 - 2012.

\begin{tabular}{|c|c|c|c|c|c|c|c|}
\hline \multirow[b]{2}{*}{ Site } & \multirow[b]{2}{*}{ Year } & \multicolumn{2}{|c|}{ Annelida } & \multicolumn{2}{|c|}{ Arthropoda } & \multicolumn{2}{|c|}{ Mollusca } \\
\hline & & Taxa Richness & $\%$ & Taxa Richness & $\%$ & Taxa Richness & $\%$ \\
\hline \multirow{7}{*}{ Elders East } & 2005 & 2 & $25.0 \%$ & 0 & $0.0 \%$ & 6 & $75.0 \%$ \\
\hline & 2006 & 1 & $33.3 \%$ & 1 & $33.3 \%$ & 1 & $33.3 \%$ \\
\hline & 2007 & 1 & $25.0 \%$ & 2 & $50.0 \%$ & 1 & $25.0 \%$ \\
\hline & 2008 & 2 & $18.2 \%$ & 7 & $63.6 \%$ & 2 & $18.2 \%$ \\
\hline & 2009 & 3 & $17.6 \%$ & 10 & $58.8 \%$ & 4 & $23.5 \%$ \\
\hline & 2010 & 2 & $15.4 \%$ & 7 & $53.8 \%$ & 4 & $30.8 \%$ \\
\hline & 2012 & 1 & $6.7 \%$ & 11 & $73.3 \%$ & 3 & $20.0 \%$ \\
\hline \multirow{5}{*}{ Elders Fertilizer } & 2007 & 1 & $50.0 \%$ & 0 & $0.0 \%$ & 1 & $50.0 \%$ \\
\hline & 2008 & 2 & $22.2 \%$ & 5 & $55.6 \%$ & 2 & $22.2 \%$ \\
\hline & 2009 & 4 & $25.0 \%$ & 6 & $37.5 \%$ & 6 & $37.5 \%$ \\
\hline & 2010 & 2 & $15.4 \%$ & 7 & $53.8 \%$ & 4 & $30.8 \%$ \\
\hline & 2012 & 2 & $13.3 \%$ & 9 & $60.0 \%$ & 4 & $26.7 \%$ \\
\hline \multirow{5}{*}{ Elders No Fertilizer } & 2007 & 1 & $20.0 \%$ & 3 & $60.0 \%$ & 1 & $20.0 \%$ \\
\hline & 2008 & 1 & $8.3 \%$ & 10 & $83.3 \%$ & 1 & $8.3 \%$ \\
\hline & 2009 & 2 & $11.8 \%$ & 9 & $52.9 \%$ & 6 & $35.3 \%$ \\
\hline & 2010 & 3 & $20.0 \%$ & 8 & $53.3 \%$ & 4 & $26.7 \%$ \\
\hline & 2012 & 1 & $9.1 \%$ & 7 & $63.6 \%$ & 3 & $27.3 \%$ \\
\hline \multirow{7}{*}{ JoCo } & 2005 & 3 & $20.0 \%$ & 9 & $60.0 \%$ & 3 & $20.0 \%$ \\
\hline & 2006 & 1 & $7.7 \%$ & 9 & $69.2 \%$ & 3 & $23.1 \%$ \\
\hline & 2007 & 2 & $14.3 \%$ & 9 & $64.3 \%$ & 3 & $21.4 \%$ \\
\hline & 2008 & 1 & $9.1 \%$ & 7 & $63.6 \%$ & 3 & $27.3 \%$ \\
\hline & 2009 & 2 & $14.3 \%$ & 8 & $57.1 \%$ & 4 & $28.6 \%$ \\
\hline & 2010 & 1 & $9.1 \%$ & 7 & $63.6 \%$ & 3 & $27.3 \%$ \\
\hline & 2012 & 1 & $6.7 \%$ & 11 & $73.3 \%$ & 3 & $20.0 \%$ \\
\hline
\end{tabular}

\subsubsection{Shannon-Wiener's Diversity}

The Shannon-Wiener Diversity Index $\left(H^{\prime}\right)$ is a widely used species diversity index that accounts for the relative abundance of each taxa as well as for taxa richness. Comparing between samples, lower values of $H^{\prime}$ indicate lower taxa richness and an uneven distribution of abundance among species, while higher values indicate higher taxa richness and an even distribution of abundance among taxa. Typically, a healthy benthic macro-invertebrate community would have a relatively high $H^{\prime}$ value. The index was computed as follows: 


$$
H^{\prime}=-\sum_{i=1}^{S}\left(p_{i} \ln p_{i}\right)
$$

where $\mathrm{S}$ is the total number of species per sample (i.e., taxa richness) and $\mathrm{p}_{\mathrm{i}}$ is the proportion of total individuals in the $\mathrm{i}^{\text {th }}$ species. Mathematically, $\mathrm{p}_{\mathrm{i}}$ is defined as $n_{i} / N$ where $n_{i}$ is the number of individuals of a taxa in a sample and $\mathrm{N}$ is the total number of individuals of all taxa in the sample.

High benthic community diversity $\left(H^{\prime} \geq 1.90\right)$ was found at Elders East in 2009, at the Elders No Fertilizer location in 2010, and at JoCo Marsh site in 2009 and 2012 (Table 6). The JoCo Marsh reference location consistently yielded a benthic diversity between 1.64 and 1.99 from 2006 through 2012, in comparison to Elders East, which started low $\left(H^{\prime} \leq 1.00\right)$ from 2005 to 2007 but increased to monitoring program highs of 2.08 in 2009. In all of the sampling years, the Elders No Fertilizer site (yearly average $=1.34$ ) had higher benthic diversity than the Elders Fertilizer site (yearly average = o.82).

\subsubsection{Pielou's Evenness}

Pielou's Evenness Index $\left(J^{\prime}\right)$ measures the distribution among species within the community by scaling one of the diversity measures relative to its maximal possible value. Evenness can range from o to 1. It was computed as follows:

$$
J^{\prime}=\frac{H^{\prime}}{H^{\prime}}{ }_{\max }
$$

where $H^{\prime}$ is the observed diversity (as cited above) and $H_{\max }^{\prime}$ is the natural logarithm of the total number of taxa $(\mathrm{S})$ in the sample $\left(H_{\max }^{\prime}=\mathrm{LnS}\right)$.

High benthic community evenness $\left(J^{\prime}>0.70\right)$ was found at Elders East in 2006, 2009, and 2010, at the Elders Fertilizer location in 2007 and 2010, at the Elders No Fertilizer location in 2010, and at JoCo Marsh in 2008, 2009, and 2012 (Table 6). However, the highest yearly values of o.86 (Elders East in 2006 and Elders Fertilizer in 2007) were the result of low taxa richness and low numbers of organisms counted. Low benthic community evenness $\left(J^{\prime} \leq 0.30\right)$ was recorded in 2005 at Elders East, but increased as the restoration site matured. Relatively low evenness $\left(J^{\prime} \leq 0.38\right)$ was also recorded at JoCo Marsh in 2005 but stayed consistently high between 0.62 and 0.76 during the subsequent years of monitoring at the reference 
location. Relatively low benthic community evenness $\left(J^{\prime} \leq 0.37\right)$ was recorded at both the Elders Fertilizer and the Elders No Fertilizer locations in 2008 and 2009, and at the Elders Fertilizer location in 2012; on average the Elders No Fertilizer treatment had slightly higher benthic community evenness over the course of the entire monitoring program ( 0.57 compared to 0.44$)$.

\subsection{Nekton}

Intertidal salt marshes provide critical habitat for nekton (free-swimming fish and crustaceans) that represent a significant food resource for piscivorous birds, fish, and marine mammals (Hettler 1989, Kneib 1986, Kneib and Wagner 1994, Peterson and Turner 1994, Weinstein 1979, Yozzo and Smith 1998). Nekton monitoring followed the protocol used in the Long-term Ecosystem Monitoring Program at Cape Cod National Seashore (Raposa and Roman 2001). In addition to the sampling at JoCo Marsh, sampling at the Elders East restoration site occurred at the southern end of the island in the low-lying southern core (Elders Lower location) and at the shallow-water fringes of the island (Elders East location).

Nekton were collected using $1 \mathrm{~m}^{2}$ throw traps (Kushlan 1974, Rozas and Odum 1987, Raposa and Roman 2001). The nekton was identified, counted, and measured (total length for fish or body length for crustaceans) at each sampling location. Only the first 15 individuals of each species were measured for length but all individuals were counted.

Nekton and corresponding water quality data were collected twice annually at shallow water ( $<1$ meter) salt marsh habitats from 2005 to 2010. The first sampling event occurred in early summer (Event 1 ) and the second occurred in late summer (Event 2). Sampling locations were determined annually using a random systematic approach and were often, but not always, revisited within the same year. Approximately 15 locations were sampled at each site during each sampling event.

\subsubsection{Community Composition}

Mummichog (Fundulus heteroclitus) was the most commonly collected nektonic species (39.6\% of the total collected), followed by horseshoe crab (18.9\%), striped killifish (Fundulus majalis (14.0\%)), daggerblade grass shrimp (Palaemonetes pugio (10.7\%)), and Atlantic silverside (Menidia menidia (9.0\%)). These species were consistently collected in all treatment 
areas across most years except for horseshoe crabs, which were not collected at the JoCo reference site. Spotfin killifish, (Fundulus luciae (6.6\% of the total)), were collected only at JoCo Marsh (Table 9). This small, cryptic fundulid is found almost exclusively in the upper intertidal zone of salt and brackish marshes, in shallow pools, and marsh surface rivulets, and has previously been reported from the Ralph Creek/Spring Creek drainage, upstream of Spring Creek Park, along the north shore of Jamaica Bay (Yozzo and Ottman 2003). Various other decapod crustacean species were collected across the treatment areas. One American eel (Anguilla rostrata) and one white mullet (Mugil curema) were also collected at JoCo Marsh.

\subsubsection{Nekton Density}

Nekton count for each species (Cs) was divided by the area of each location sampling event $\left(1 \mathrm{~m}^{2}\right)$ to yield a density (Ds) for each species expressed as number per $\mathrm{m}^{2}$.

$$
D_{S}=\frac{C_{S}}{1 m^{2}}
$$

Nekton density for each treatment site and year was averaged by the number of locations sampled for each site and sampling event to return an average nekton density for each site, sampling event, and year.

High nekton densities were recorded in 2008 during the early summer sampling event at the Elders East (168 organisms per $\mathrm{m}^{2}$ ) and Elders Lower (162 organisms per $\mathrm{m}^{2}$ ) locations (Table 10), and were primarily driven by the high number of horseshoe crabs at these two locations.

Relatively high nekton densities ( $>50$ organisms per $\mathrm{m}^{2}$ ) were consistently recorded at JoCo Marsh during the late summer event in comparison to lower densities at Elders East $\left(<30\right.$ organisms per $\left.\mathrm{m}^{2}\right)$. This pattern persisted from 2005 to 2007 during the late summer sampling event. Nekton densities at Elders East peaked in 2008 (168 organisms per m²) and then again in 2010 ( 88 organisms per $\mathrm{m}^{2}$ ) during the early summer event. On average, nekton densities were high during the early summer sampling event at Elders East and Elders Lower. This trend was reversed at JoCo, which had a higher average density during the late summer sampling event (67 organisms per $\mathrm{m}^{2}$ ) compared to the early summer event (43 organisms per $\mathrm{m}^{2}$ ). Total early summer nekton density at Elders East and JoCo Marsh differed significantly $(p<0.05)$ in 2005, 2006, and 
2008 (Appendix A; Table A-8). During late summer, total nekton density differed significantly $(\mathrm{p}<0.05)$ between Elders East and JoCo in 2006 and 2008 (Appendix A; Table A-8). Total nekton density was not significantly different ( $p>0.05$ ) when comparing either Elders East and Elders Lower or comparing Elders Lower and JoCo during both sampling events and all years of the monitoring program (Appendix A; Table A-8 and A-9).

\subsubsection{Taxa Richness}

Between 4 and 7 nekton taxa were collected during each sampling event at each site during each year of the monitoring program (Table 10). On average, over all of the sampling years and both yearly events, Elders Lower had slightly higher taxa richness (average $=5.9$ taxa) compared to Elders East (5.3 taxa) and JoCo (5.0 taxa). The most consistently collected taxon was mummichog, which was collected at each location during each event and each year (Table 10).

\subsubsection{Shannon-Wiener's Diversity}

In general, diversity was low within the nekton samples with the highest diversity occurring at the Elders Lower site in 2010 during the early summer event (1.45) and in 2009 during the late summer event (1.37); diversity was also higher at the Elders East site in 2009 during the late summer event (1.30) (Table 10). Diversity greater than 1.0 was only recorded once at JoCo Marsh (1.15 in 2006 during the late summer event), which had low diversity (<0.60) during the early summer event in 2005 and 2009, and during the late summer event in 2010. On average, over all of the sampling years and both yearly events, taxa richness was slightly higher at Elders Lower (average $\left.H^{\prime}=1.14\right)$ compared to Elders East $\left(H^{\prime}=1.01\right)$ and JoCo Marsh $\left(H^{\prime}=0.71\right)$.

\subsubsection{Pielou's Evenness}

Pielou's Evenness Index $\left(J^{\prime}\right)$ was calculated as per above for the nekton community. In general, the distribution among species collected within the nekton sampling was moderate with the highest evenness occurring during the late summer sampling event at the Elders Lower site in 2009 (0.85), at the Elders East site in 2007 (0.84), and at JoCo Marsh in 2006 (0.83) (Table 10). On average, over all of the sampling years and both yearly events, evenness was slightly higher at Elders Lower (average $J^{\prime}=0.65$ ) and Elders East $\left(J^{\prime}=0.61\right)$ compared to the JoCo Marsh site $\left(J^{\prime}=0.45\right)$ (Table 10). 
Table 9. Count of nekton collected at Elders Island monitoring sites, 2005-2010.

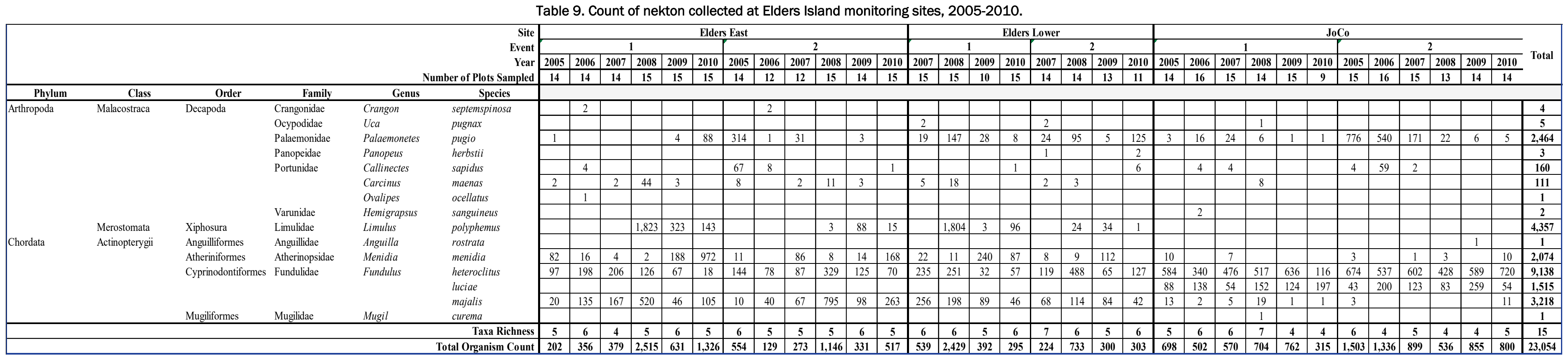


Table 10. Nekton community indices: true taxa richness, total organism count, average density by sample plot (no. organisms $/ \mathrm{m}^{2}$ ), Shannon-Weiner's diversity $\left(\mathrm{H}^{\prime}\right)$, and Pielou's evenness $\left(\mathrm{J}^{\prime}\right)$; Elders Island monitoring sites, 2005 - 2010.

\begin{tabular}{|c|c|c|c|c|c|c|c|}
\hline Site & Event & Year & Taxa Richness & \begin{tabular}{|l|} 
Total Count \\
\end{tabular} & Average Density & $\mathrm{H}^{\prime}$ & $J^{\prime}$ \\
\hline \multirow{12}{*}{ Elders East } & \multirow{6}{*}{1} & 2005 & 5 & 202 & 14 & 1.02 & 0.63 \\
\hline & & 2006 & 6 & 356 & 25 & 0.93 & 0.52 \\
\hline & & 2007 & 4 & 379 & 27 & 0.77 & 0.55 \\
\hline & & 2008 & 5 & 2,515 & 168 & 0.79 & 0.49 \\
\hline & & 2009 & 6 & 631 & 42 & 1.19 & 0.66 \\
\hline & & 2010 & 5 & 1,326 & 88 & 0.91 & 0.56 \\
\hline & \multirow{6}{*}{2} & 2005 & 6 & 554 & 40 & 1.14 & 0.64 \\
\hline & & 2006 & 5 & 129 & 11 & 0.94 & 0.59 \\
\hline & & 2007 & 5 & 273 & 23 & 1.36 & 0.84 \\
\hline & & 2008 & 5 & 1,146 & 76 & 0.71 & 0.44 \\
\hline & & 2009 & 6 & 331 & 24 & 1.30 & 0.73 \\
\hline & & 2010 & 5 & 517 & 34 & 1.09 & 0.68 \\
\hline \multirow{8}{*}{ Elders Lower } & \multirow{4}{*}{1} & 2007 & 6 & 539 & 36 & 1.03 & 0.57 \\
\hline & & 2008 & 6 & 2,429 & 162 & 0.89 & 0.50 \\
\hline & & 2009 & 5 & 392 & 39 & 1.07 & 0.66 \\
\hline & & 2010 & 6 & 295 & 20 & 1.45 & 0.81 \\
\hline & \multirow{4}{*}{2} & 2007 & 7 & 224 & 16 & 1.16 & 0.60 \\
\hline & & 2008 & 6 & 733 & 52 & 1.01 & 0.57 \\
\hline & & 2009 & 5 & 300 & 23 & 1.37 & 0.85 \\
\hline & & 2010 & 6 & 303 & 28 & 1.13 & 0.63 \\
\hline \multirow{12}{*}{ JoCo } & \multirow{6}{*}{1} & 2005 & 5 & 698 & 50 & 0.57 & 0.35 \\
\hline & & 2006 & 6 & 502 & 31 & 0.81 & 0.45 \\
\hline & & 2007 & 6 & 570 & 38 & 0.64 & 0.36 \\
\hline & & 2008 & 7 & 704 & 50 & 0.77 & 0.39 \\
\hline & & 2009 & 4 & 762 & 51 & 0.46 & 0.33 \\
\hline & & 2010 & 4 & 315 & 35 & 0.70 & 0.50 \\
\hline & \multirow{6}{*}{2} & 2005 & 6 & 1,503 & 100 & 0.84 & 0.47 \\
\hline & & 2006 & 4 & 1,336 & 84 & 1.15 & 0.83 \\
\hline & & 2007 & 5 & 899 & 60 & 0.88 & 0.55 \\
\hline & & 2008 & 4 & 536 & 41 & 0.63 & 0.45 \\
\hline & & 2009 & 4 & 855 & 61 & 0.66 & 0.48 \\
\hline & & 2010 & 5 & 800 & 57 & 0.42 & 0.26 \\
\hline
\end{tabular}




\subsubsection{Length}

Table 11 presents the minimum, maximum, and average length for each measured nekton species collected. Mummichog was the most measured species $(n=3,315)$ and ranged in total length (TL) from 6 to $94 \mathrm{~mm}$ with an average TL of $33 \mathrm{~mm}$, suggesting that most were young-of-the-year (less than one year old). Additional killifish species and Atlantic silversides were also typically less than $40 \mathrm{~mm}$ TL on average, suggesting that they too were predominantly young-of-the-year using the marsh areas as nursery habitat (Able and Fahay 2010). Horseshoe crabs were also measured in large numbers $(n=757)$ and ranged in body length from 2 to $74 \mathrm{~mm}$ with an average size of $4 \mathrm{~mm}$, suggesting that the vast majority were newly hatched young-of-the-year.

Table 11. Minimum, maximum, and average length for measured individuals of all nektonic species collected at Elders Island monitoring sites, 2005 - 2010.

\begin{tabular}{|l|l|c|c|c|c|}
\hline & & \multirow{2}{*}{$\begin{array}{c}\text { Number } \\
\text { Common Name }\end{array}$} & \multicolumn{3}{|c|}{ Length (mm)* $^{*}$} \\
\cline { 4 - 6 } & Scientific Name & 4 & 18 & 25 & 22 \\
\hline Sevenspine bay shrimp & Crangon septemspinosa & 5 & 9 & 19 & 13 \\
\hline Atlantic marsh fiddler crab & Uca pugnax & Minimum & Maximum & Average \\
\hline Daggerblade grass shrimp & Palaemonetes pugio & 675 & 2 & 40 & 23 \\
\hline Atlantic mud crab & Panopeus herbstii & 3 & 5 & 15 & 10 \\
\hline Blue crab & Callinectes sapidus & 148 & 4 & 152 & 21 \\
\hline Green crab & Carcinus maenas & 111 & 2 & 36 & 8 \\
\hline Lady crab & Ovalipes ocellatus & 1 & 20 & 20 & 20 \\
\hline Asian shore crab & Hemigrapsus sanguineus & 2 & 3 & 5 & 4 \\
\hline Horseshoe crab & Limulus polyphemus & 757 & 2 & 74 & 4 \\
\hline American eel & Anguilla rostrata & 1 & 95 & 95 & 95 \\
\hline Atlantic silverside & Menidia menidia & 608 & 9 & 77 & 37 \\
\hline Mummichog & Fundulus heteroclitus & 3,315 & 6 & 94 & 33 \\
\hline Spotfin killifish & Fundulus luciae & 735 & 10 & 42 & 24 \\
\hline Striped killifish & Fundulus majalis & 1,555 & 8 & 90 & 36 \\
\hline White mullet & Mugil curema & 1 & 31 & 31 & 31 \\
\hline
\end{tabular}

*For crustacean species, body length; for fish species, total length

Figure 14 shows the length frequency distributions of the most commonly collected nekton species at the Elders East, Elders Lower, and JoCo Marsh sites. Subtle differences between treatment areas were noted for some species, including daggerblade grass shrimp and blue crab (Callinectes 
sapidus). The dominant size class of daggerblade grass shrimp, for example, measured between 20 and $24 \mathrm{~mm}$ at JoCo Marsh compared to between 14 and $18 \mathrm{~mm}$ at Elders Lower and between 26 and $30 \mathrm{~mm}$ at Elders East. The largest blue crabs ( $\geq 85 \mathrm{~mm}$ ) were all collected at JoCo Marsh, while the dominant blue crab size classes at Elders East and Elders Lower measured between 10 and $15 \mathrm{~mm}$ and between 40 and $80 \mathrm{~mm}$, respectively, suggesting that the Elders East site was providing habitat for newly recruited juvenile blue crabs. When compared to JoCo Marsh, peak length distributions were slightly smaller at Elders East for Atlantic silversides and slightly larger at Elders East for striped killifish, mummichogs, and daggerblade grass shrimp. Peak length distributions were comparable between these two sites for blue crabs and green crabs (Carcinus maenas), while horseshoe crabs were comparable between Elders East and Elders Lower. No horseshoe crabs were collected at JoCo Marsh (Figure 14).

Figure 14. Length-frequency distributions for most commonly measured invertebrate species collected in nekton samples at Elders Point monitoring sites, 2005 - 2010. (Continued)
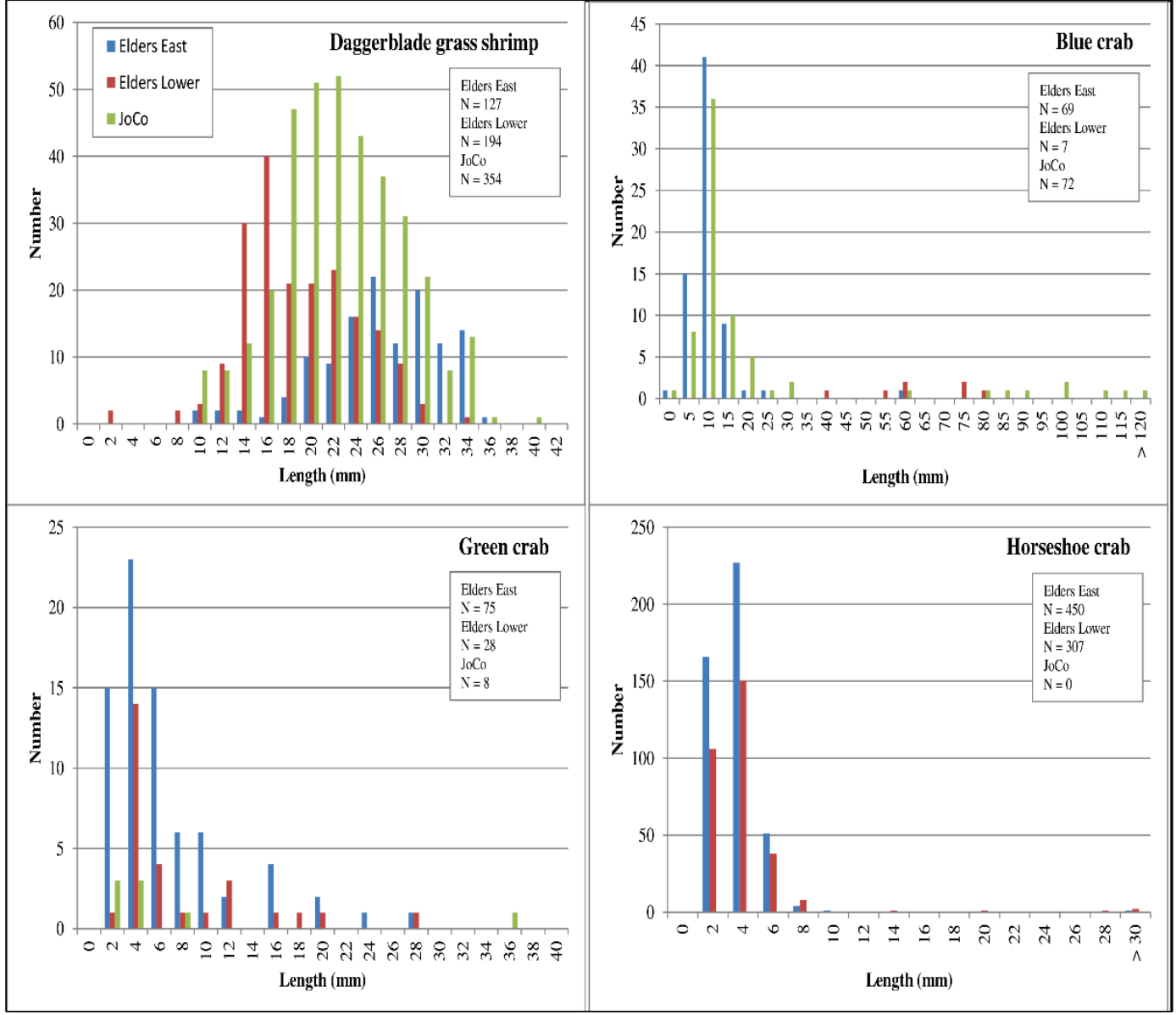
Figure 14. (Concluded).

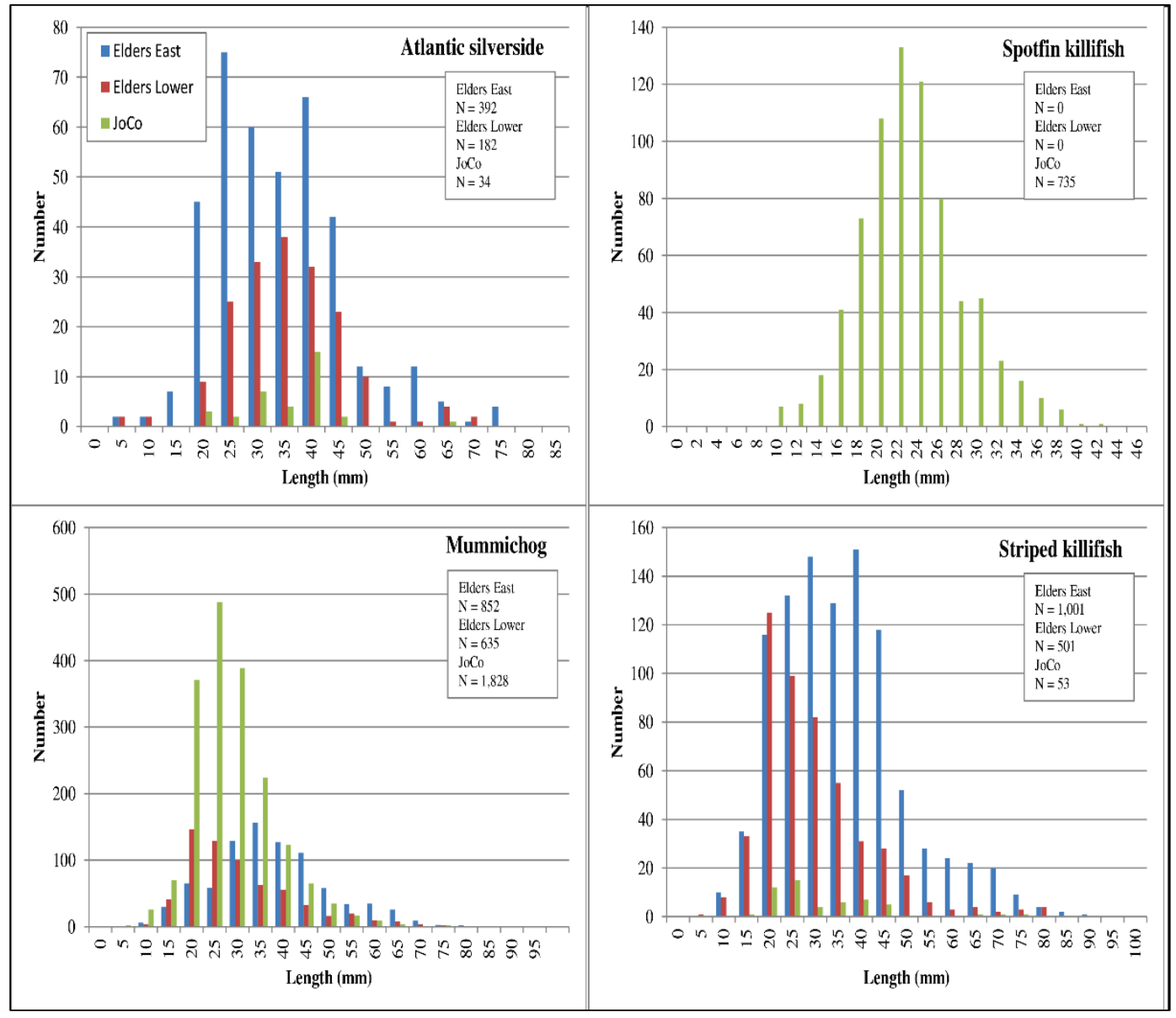

\subsection{Birds}

Observational bird counts were recorded within two hours of low tide at both the Elders East restoration and JoCo Marsh reference sites from 2006 to 2010 using a fixed-radius, point-count technique described in USACE-NYD (2007). Sample duration was ten minutes, during which all avian species, counts, and activities were recorded. These observations were followed by a site walk-through to flush any hidden birds from the survey area. Opportunistic bird observations were also noted throughout the survey day as well as general observations on geese rooting and grazing impacts, and observations for signs of marsh bird predation from resident mammals and reptiles. Observational data were classified into six locational categories: on water and over water; on marsh and over marsh; and on shore and over shore.

A total of 25,699 birds from 36 species were observed at Elders East and JoCo Marshes from 2006 through 2010 (Table 12). The majority consisted 
of waterfowl as well as gulls and terns, including Brant (Branta bernicla (61.9\% of the total)), Herring Gull (Larus argentatus (21.0\%)), Laughing Gull (Larus atricilla (4.0\%)), Black Duck (Anas rubripes (2.6\%)), Doublecrested Cormorant (Phalacrocorax auritus (2.0\%)), and Ring-billed Gull (Larus delawarensis (2.0\%)). Although more surveys were conducted at Elders East, proportionally more birds were observed at Elders East compared to JoCo, especially in 2006 and 2007, during the restoration construction when $27 \%$ and $59 \%$ of the surveyed birds were recorded, respectively. The majority of the birds observed at Elders East in 2006 and 2007 were Brant (75.1\% and $64.1 \%$ of the total, respectively).

Table 12. Bird species observed by year, Elders Island monitoring sites, 2006 - 2010.

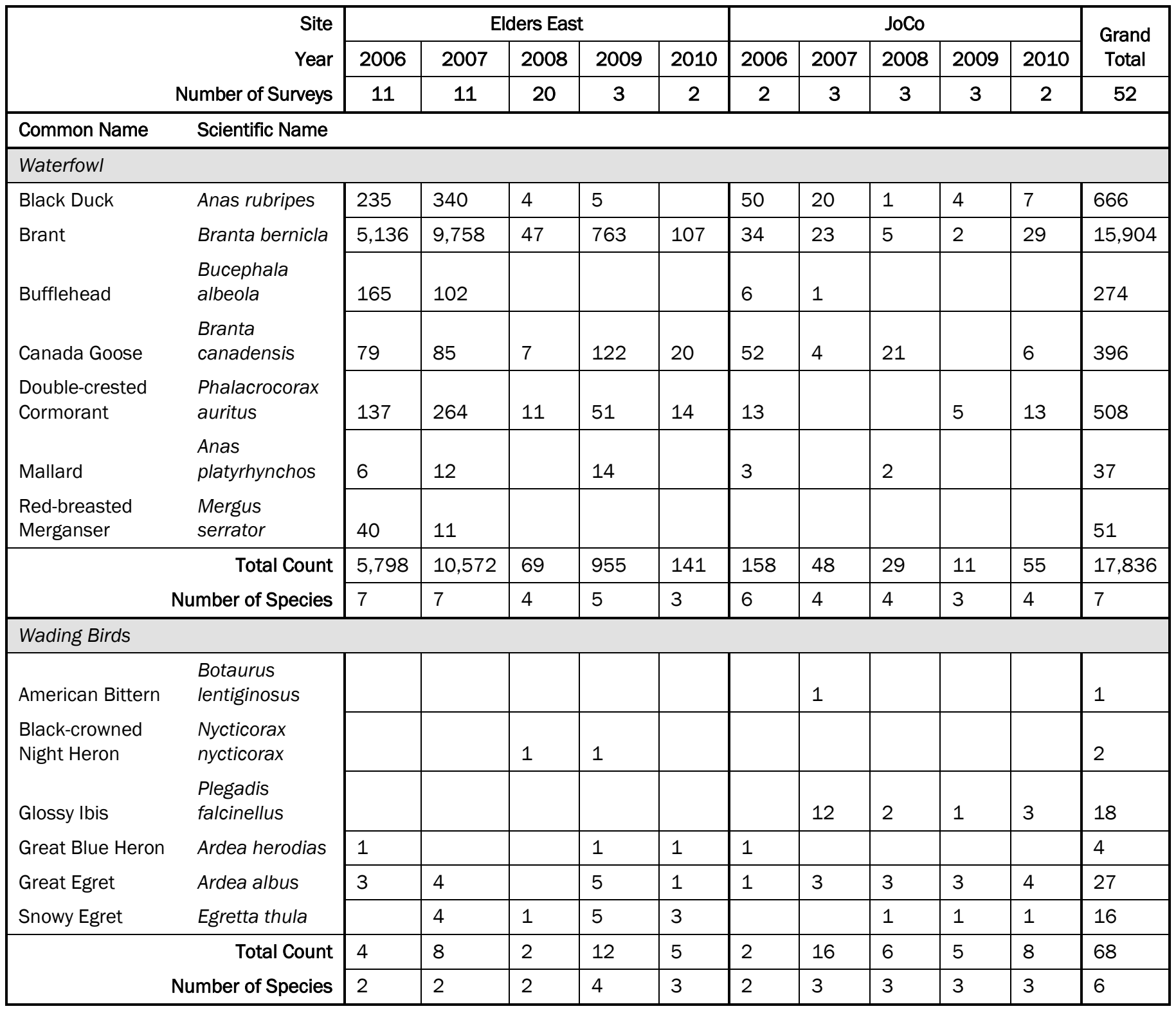




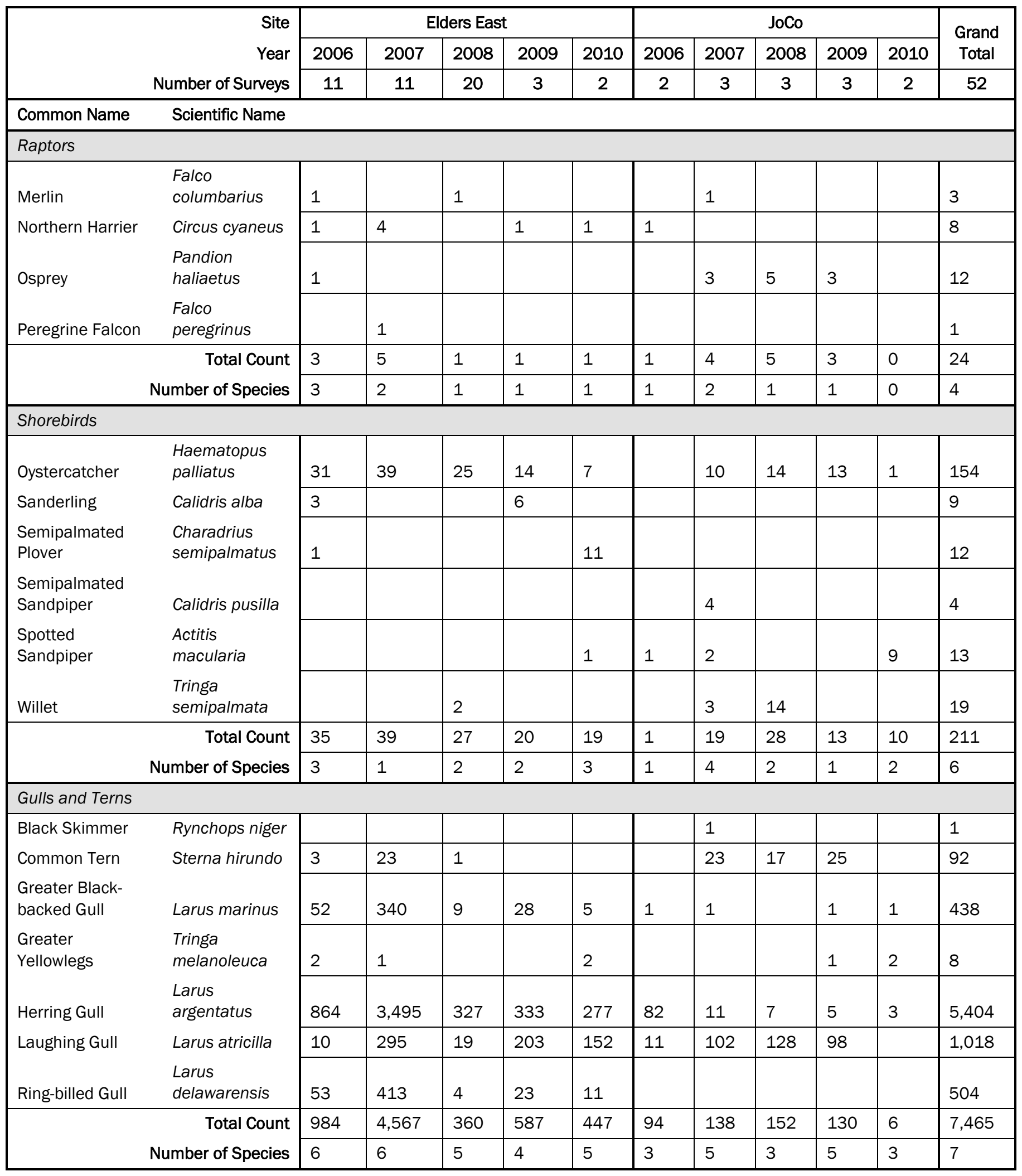




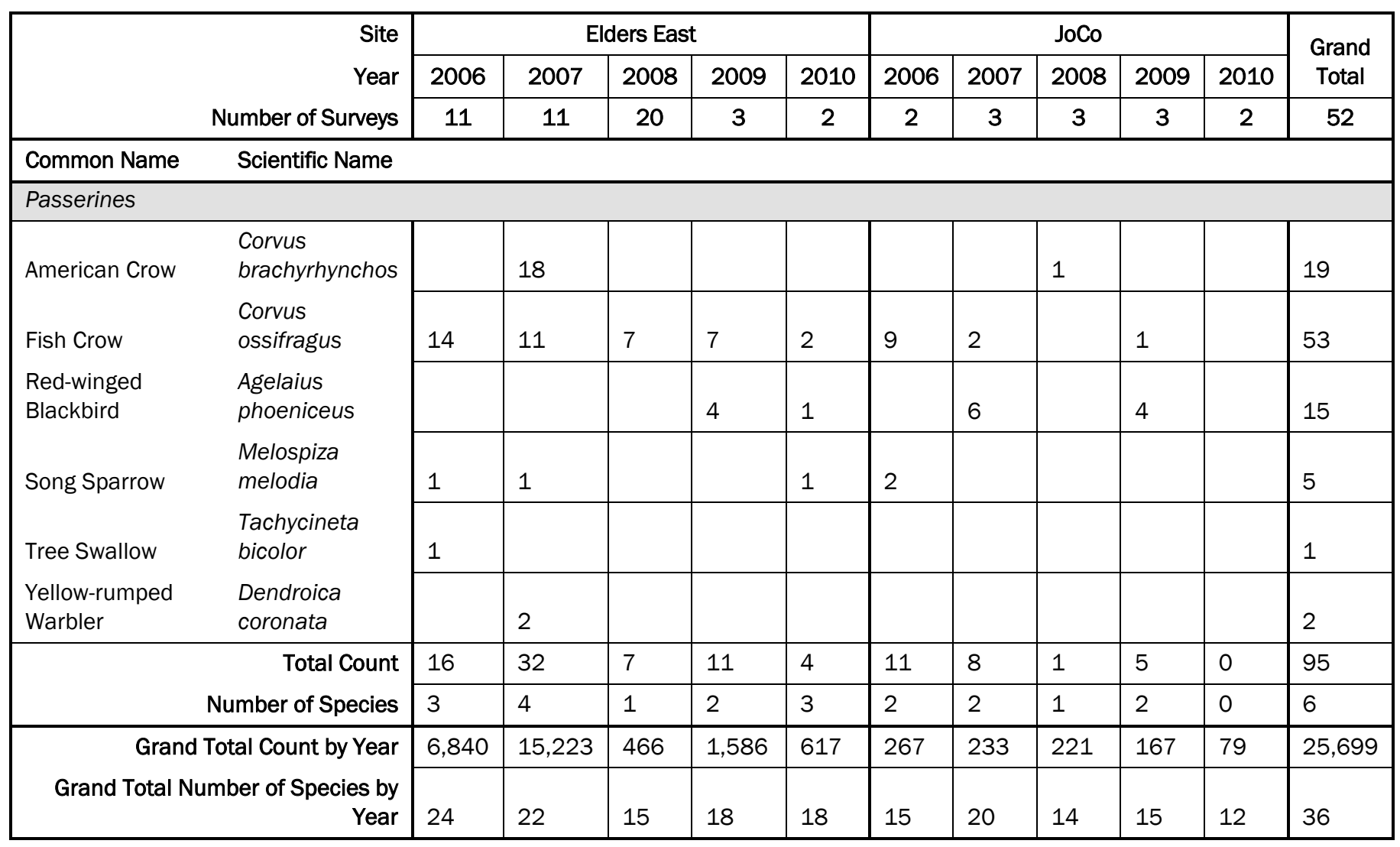

Species richness was also highest during 2006 and 2007 at Elders East (24 and 22 different species observed, respectively). The fewest number of birds and species at Elders East were observed in the first year of postconstruction monitoring (2008) despite the highest number of surveys (20) but rebounded in 2009 to comparable levels given that only three surveys were done at Elders East in 2009. From 2006 to 2009, between 167 and 267 birds representing between 14 and 20 different species were consistently recorded at JoCo Marsh. In 2010, species richness and the total number of birds counted were down slightly at both JoCo and Elders East marshes, but this result may have been driven primarily by level of effort as only two bird surveys were conducted at each location in 2010. The most commonly observed wading birds were the Great Egret (Ardea alba); the most common shorebird was Oystercatcher (Haematopus palliatus), the most common passerine was Fish Crow (Corvus ossifragus), and the most common raptor was Osprey (Pandion haliaetus). Ospreys were found almost exclusively at JoCo Marsh except for one observation at Elders East in 2006. One Peregrine Falcon (Falco peregrinus) observation was also made at Elders East in 2007 (Table 12). 
Table 13 presents the results by season for Elders East and JoCo Marshes. The surveying effort was focused during the fall migration period (October through December) and during winter (January through March) at Elders East only, but also captured the spring migration period (April through June) at both sites. Species richness peaked during the fall at both Elders East (29 species) and JoCo (22 species), while total bird counts peaked during the fall at Elders East $(n=15,792)$ and during the winter at JoCo Marsh ( $n=504)$. As expected, seasonal trends in species occurrence were also apparent, including in the fall and winter when most of the waterfowl species, including Brant, Buffleheads (Bucephala albeola) and Black Ducks, were most common. Canada Geese and Double-crested Cormorants occurred year round at Elders East, while Canada Geese were most common in the spring at Elders East and in the fall at JoCo Marsh; Double-Crested Cormorants were most common in the fall at both locations. The most common gull species also tended to occur year round at Elders East (Table 13).

Table 13. Bird species observed by season, Elders Island monitoring sites, 2006 - 2010.

\begin{tabular}{|c|c|c|c|c|c|c|c|c|c|c|}
\hline \multirow{3}{*}{\multicolumn{2}{|c|}{$\begin{array}{r}\text { Site } \\
\text { Season }^{1} \\
\text { Number of Surveys }\end{array}$}} & \multicolumn{4}{|c|}{ Elders East } & \multicolumn{4}{|c|}{ JoCo } & \multirow{2}{*}{$\begin{array}{c}\text { Grand } \\
\text { Total }\end{array}$} \\
\hline & & Winter & Spring & Summer & Fall & Winter & Spring & Summer & Fall & \\
\hline & & 12 & 9 & 1 & 25 & 0 & 4 & 1 & 8 & 52 \\
\hline \multicolumn{11}{|c|}{ Scientific Name } \\
\hline \multicolumn{11}{|l|}{ Waterfowl } \\
\hline Black Duck & Anas rubripes & 26 & 1 & & 557 & \multirow{9}{*}{ ND } & & 3 & 79 & 666 \\
\hline Brant & Branta bernicla & 2,382 & 1,801 & & 11,628 & & 17 & & 76 & 15,904 \\
\hline Bufflehead & $\begin{array}{l}\text { Bucephala } \\
\text { albeola }\end{array}$ & 82 & 14 & & 171 & & & & 7 & 274 \\
\hline Canada Goose & $\begin{array}{l}\text { Branta } \\
\text { canadensis }\end{array}$ & 52 & 126 & 20 & 115 & & 4 & & 79 & 396 \\
\hline $\begin{array}{l}\text { Double-crested } \\
\text { Cormorant }\end{array}$ & $\begin{array}{l}\text { Phalacrocorax } \\
\text { auritus }\end{array}$ & 82 & 84 & 3 & 308 & & & 10 & 21 & 508 \\
\hline Mallard & $\begin{array}{l}\text { Anas } \\
\text { platyrhynchos }\end{array}$ & & 15 & & 17 & & 2 & & 3 & 37 \\
\hline $\begin{array}{l}\text { Red-breasted } \\
\text { Merganser }\end{array}$ & Mergus serrator & 9 & 2 & & 40 & & & & & 51 \\
\hline \multirow{2}{*}{\multicolumn{2}{|c|}{$\begin{array}{r}\text { Total Count } \\
\text { Number of Species }\end{array}$}} & 2,633 & 2,043 & 23 & 12,836 & & 23 & 13 & 265 & 17,836 \\
\hline & & 6 & 7 & 2 & 7 & & 3 & 2 & 6 & 7 \\
\hline \multicolumn{11}{|l|}{ Wading Birds } \\
\hline $\begin{array}{l}\text { American } \\
\text { Bittern }\end{array}$ & $\begin{array}{l}\text { Botaurus } \\
\text { lentiginosus }\end{array}$ & & & & & \multirow{2}{*}{ ND } & & & 1 & 1 \\
\hline $\begin{array}{l}\text { Black-crowned } \\
\text { Night Heron }\end{array}$ & $\begin{array}{l}\text { Nycticorax } \\
\text { nycticorax }\end{array}$ & & 1 & & 1 & & & & & 2 \\
\hline
\end{tabular}




\begin{tabular}{|c|c|c|c|c|c|c|c|c|c|c|}
\hline \multirow{3}{*}{\multicolumn{2}{|c|}{$\begin{array}{r}\text { Site } \\
\text { Season }^{1} \\
\text { Number of Surveys }\end{array}$}} & \multicolumn{4}{|c|}{ Elders East } & \multicolumn{4}{|c|}{ JoCo } & \multirow{2}{*}{$\begin{array}{l}\text { Grand } \\
\text { Total }\end{array}$} \\
\hline & & Winter & Spring & Summer & Fall & Winter & Spring & Summer & Fall & \\
\hline & & 12 & 9 & 1 & 25 & 0 & 4 & 1 & 8 & 52 \\
\hline Common Name & \multicolumn{10}{|l|}{ Scientific Name } \\
\hline \multirow{3}{*}{$\begin{array}{l}\text { Glossy Ibis } \\
\text { Great Blue } \\
\text { Heron } \\
\text { Great Egret } \\
\text { Snowy Egret }\end{array}$} & $\begin{array}{l}\text { Plegadis } \\
\text { falcinellus }\end{array}$ & & & & & & 13 & 3 & 2 & 18 \\
\hline \multirow{3}{*}{$\begin{array}{l}\text { Great Blue } \\
\text { Heron } \\
\text { Great Egret } \\
\text { Snowy Egret }\end{array}$} & \multirow{3}{*}{$\begin{array}{l}\text { Ardea herodias } \\
\text { Ardea albus } \\
\text { Egretta thula }\end{array}$} & & & 1 & 2 & & & & 1 & 4 \\
\hline & & & 2 & & 11 & & 4 & 3 & 7 & 27 \\
\hline & & & 6 & 3 & 4 & & 1 & 1 & 1 & 16 \\
\hline & \multirow{2}{*}{$\begin{array}{r}\text { Total Count } \\
\text { Number of Species }\end{array}$} & 0 & 9 & 4 & 18 & & 18 & 7 & 12 & 68 \\
\hline & & 0 & 3 & 2 & 4 & & 3 & 3 & 5 & 6 \\
\hline \multicolumn{11}{|l|}{ Raptors } \\
\hline Merlin & $\begin{array}{l}\text { Falco } \\
\text { columbarius }\end{array}$ & & & & 2 & \multirow{6}{*}{ ND } & & & 1 & 3 \\
\hline $\begin{array}{l}\text { Northern } \\
\text { Harrier }\end{array}$ & Circus cyaneus & 4 & & & 3 & & & & 1 & 8 \\
\hline Osprey & $\begin{array}{l}\text { Pandion } \\
\text { haliaetus }\end{array}$ & & & & 1 & & 10 & & 1 & 12 \\
\hline $\begin{array}{l}\text { Peregrine } \\
\text { Falcon }\end{array}$ & Falco peregrinus & & & & 1 & & & & & 1 \\
\hline & Total Count & 4 & 0 & 0 & 7 & & 10 & 0 & 3 & 24 \\
\hline & Number of Species & 1 & 0 & 0 & 4 & & 1 & 0 & 3 & 4 \\
\hline \multicolumn{11}{|l|}{ Shorebirds } \\
\hline \multirow{6}{*}{$\begin{array}{l}\text { Oystercatcher } \\
\text { Sanderling } \\
\text { Semipalmated } \\
\text { Plover } \\
\text { Semipalmated } \\
\text { Sandpiper } \\
\text { Spotted } \\
\text { Sandpiper }\end{array}$} & $\begin{array}{l}\text { Haematopus } \\
\text { palliatus }\end{array}$ & 6 & 67 & 7 & 36 & \multirow{8}{*}{ ND } & 37 & 1 & & 154 \\
\hline & Calidris alba & & 6 & & 3 & & & & & 9 \\
\hline & $\begin{array}{l}\text { Charadrius } \\
\text { semipalmatus }\end{array}$ & & & 11 & 1 & & & & & 12 \\
\hline & Calidris pusilla & & & & & & 4 & & & 4 \\
\hline & \multirow{2}{*}{$\begin{array}{l}\text { Actitis macularia } \\
\text { Tringa } \\
\text { semipalmata }\end{array}$} & & & 1 & & & 2 & 9 & 1 & 13 \\
\hline & & & 2 & & & & 17 & & & 19 \\
\hline & \multirow{2}{*}{$\begin{array}{l}\text { Total Count } \\
\text { Number of Species }\end{array}$} & 6 & 75 & 19 & 40 & & 60 & 10 & 1 & 211 \\
\hline & & 1 & 3 & 3 & 3 & & 4 & 2 & 1 & 6 \\
\hline \multicolumn{11}{|l|}{ Gulls and Terns } \\
\hline Black Skimmer & Rynchops niger & & & & & \multirow{4}{*}{ ND } & 1 & & & 1 \\
\hline Common Tern & Sterna hirundo & & 24 & & 3 & & 65 & & & 92 \\
\hline $\begin{array}{l}\text { Greater Black- } \\
\text { backed Gull }\end{array}$ & Larus marinus & 164 & 116 & 2 & 152 & & 1 & & 3 & 438 \\
\hline $\begin{array}{l}\text { Greater } \\
\text { Yellowlegs }\end{array}$ & $\begin{array}{l}\text { Tringa } \\
\text { melanoleuca }\end{array}$ & & & 2 & 3 & & & 1 & 2 & 8 \\
\hline
\end{tabular}




\begin{tabular}{|c|c|c|c|c|c|c|c|c|c|c|}
\hline \multirow{3}{*}{\multicolumn{2}{|c|}{$\begin{array}{r}\text { Site } \\
\text { Season }^{1} \\
\text { Number of Surveys }\end{array}$}} & \multicolumn{4}{|c|}{ Elders East } & \multicolumn{4}{|c|}{ JoCo } & \multirow{2}{*}{$\begin{array}{l}\text { Grand } \\
\text { Total }\end{array}$} \\
\hline & & Winter & Spring & Summer & Fall & Winter & Spring & Summer & Fall & \\
\hline & & 12 & 9 & 1 & 25 & 0 & 4 & 1 & 8 & 52 \\
\hline Common Name & \multicolumn{10}{|l|}{ Scientific Name } \\
\hline \multirow{3}{*}{$\begin{array}{l}\text { Herring Gull } \\
\text { Laughing Gull } \\
\text { Ring-billed Gull }\end{array}$} & \multirow{3}{*}{$\begin{array}{l}\text { Larus argentatus } \\
\text { Larus atricilla } \\
\text { Larus } \\
\text { delawarensis }\end{array}$} & 1,896 & 1,218 & 136 & 2,046 & & 16 & 1 & 91 & 5,404 \\
\hline & & & 41 & 151 & 487 & & 299 & & 40 & 1,018 \\
\hline & & 266 & 68 & 1 & 169 & & & & & 504 \\
\hline & \multirow{2}{*}{$\begin{array}{r}\text { Total Count } \\
\text { Number of Species }\end{array}$} & 2,326 & 1,467 & 292 & 2,860 & & 382 & 2 & 136 & 7,465 \\
\hline & & 3 & 5 & 5 & 6 & & 5 & 2 & 4 & 7 \\
\hline \multicolumn{11}{|l|}{ Passerines } \\
\hline \multirow[t]{2}{*}{ American Crow } & $\begin{array}{l}\text { Corvus } \\
\text { brachyrhynchos }\end{array}$ & 2 & 13 & & 3 & \multirow{8}{*}{ ND } & 1 & & & 19 \\
\hline & $\begin{array}{l}\text { Corvus } \\
\text { ossifragus }\end{array}$ & & 17 & 2 & 22 & & 2 & & 10 & 53 \\
\hline $\begin{array}{l}\text { Fish Crow } \\
\text { Red-winged } \\
\text { Blackbird }\end{array}$ & $\begin{array}{l}\text { Agelaius } \\
\text { phoeniceus }\end{array}$ & & 4 & 1 & & & 8 & & 2 & 15 \\
\hline Song Sparrow & $\begin{array}{l}\text { Melospiza } \\
\text { melodia }\end{array}$ & & & & 3 & & & & 2 & 5 \\
\hline \multirow{2}{*}{$\begin{array}{l}\text { Tree Swallow } \\
\text { Yellow-rumped } \\
\text { Warbler }\end{array}$} & \multirow{2}{*}{$\begin{array}{l}\text { Tachycineta } \\
\text { bicolor } \\
\text { Dendroica } \\
\text { coronata }\end{array}$} & & & & 1 & & & & & 1 \\
\hline & & & & & 2 & & & & & 2 \\
\hline & \multirow{2}{*}{$\begin{array}{r}\text { Total Count } \\
\text { Number of Species }\end{array}$} & 2 & 34 & 3 & 31 & & 11 & 0 & 14 & 95 \\
\hline & & 1 & 3 & 2 & 5 & & 3 & 0 & 3 & 6 \\
\hline \multirow{2}{*}{\multicolumn{2}{|c|}{$\begin{array}{r}\text { Grand Total Count by Season } \\
\text { Grand Total Number of Species By } \\
\text { Season }\end{array}$}} & 4,971 & 3,628 & 341 & 15,792 & \multirow{2}{*}{ ND } & 504 & 32 & 431 & 25,699 \\
\hline & & 12 & 21 & 14 & 29 & & 19 & 9 & 22 & 36 \\
\hline
\end{tabular}

Notes: 1 - Winter $=$ Jan/Feb/Mar, Spring = April/May/June, Summer $=$ Jul/Aug/Sep, Fall = Oct/Nov/Dec ND - No data (no bird surveys conducted at JoCo during Winter)

Table 14 presents the results by observed location. At Elders East the highest number of birds were observed on water $(n=13,671)$ and on shore $(n=5,776)$, although the highest species richness values were associated with over water ( 24 species) and over marsh (23 species) counts compared to JoCo Marsh, which had the highest total counts $(n=526)$ and species richness (24 species) over marsh and very low counts $(n=24)$ and richness (9 species) on shore in comparison to Elders East (Table 14). 
Table 14. Bird species observed by location, Elders Island monitoring sites, 2006 - 2010.

\begin{tabular}{|c|c|c|c|c|c|c|c|c|c|c|c|c|c|c|}
\hline & Site & \multicolumn{6}{|c|}{ Elders East } & \multicolumn{6}{|c|}{$\mathrm{J}_{0} \mathrm{C}_{0}$} & \multirow{2}{*}{$\begin{array}{c}\text { Grand } \\
\text { Total }\end{array}$} \\
\hline & Location & $\begin{array}{c}\text { On } \\
\text { Marsh }\end{array}$ & $\begin{array}{c}\text { Over } \\
\text { Marsh }\end{array}$ & On Water & $\begin{array}{c}\text { Over } \\
\text { Water }\end{array}$ & On Shore & $\begin{array}{l}\text { Over } \\
\text { Shore }\end{array}$ & $\begin{array}{c}\text { On } \\
\text { Marsh }\end{array}$ & $\begin{array}{c}\text { Over } \\
\text { Marsh }\end{array}$ & On Water & $\begin{array}{c}\text { Over } \\
\text { Water }\end{array}$ & On Shore & $\begin{array}{c}\text { Over } \\
\text { Shore }\end{array}$ & \\
\hline & Number of Surveys & \multicolumn{6}{|c|}{47} & \multicolumn{6}{|c|}{13} & 52 \\
\hline Common Name & Scientific Name & & & & & & & & & & & & & \\
\hline \multicolumn{15}{|l|}{ Waterfowl } \\
\hline Black Duck & Anas rubripes & 5 & 14 & 518 & 11 & 36 & & 2 & 33 & 45 & 2 & & & 666 \\
\hline Brant & Branta bernicla & 1 & 272 & 12,005 & 1,309 & 2,160 & 64 & & 39 & 17 & 12 & & 25 & 15,904 \\
\hline Bufflehead & Bucephala albeola & & & 231 & 36 & & & & 2 & 4 & 1 & & & 274 \\
\hline Canada Goose & Branta canadensis & 14 & 168 & 42 & 28 & 51 & 10 & 5 & 70 & 2 & & 6 & & 396 \\
\hline Double-crested Cormorant & Phalacrocorax auritus & 3 & 25 & 67 & 124 & 242 & 16 & & 6 & 19 & 6 & & & 508 \\
\hline Mallard & Anas platyrhynchos & & 1 & 15 & 1 & 15 & & & 2 & 3 & & & & 37 \\
\hline Red-breasted Merganser & Mergus serrator & & & 47 & 4 & & & & & & & & & 51 \\
\hline Total Count & & 23 & 480 & 12,925 & 1,513 & 2,504 & 90 & 7 & 152 & 90 & 21 & 6 & 25 & 17,836 \\
\hline Number of Species & & 4 & 5 & 7 & 7 & 5 & 3 & 2 & 6 & 6 & 4 & 1 & 1 & 7 \\
\hline \multicolumn{15}{|l|}{ Wading Birds } \\
\hline American Bittern & Botaurus lentiginosus & & & & & & & & 1 & & & & & 1 \\
\hline Black-crowned Night Heron & Nycticorax nycticorax & & & & 2 & & & & & & & & & 2 \\
\hline Glossy Ibis & Plegadis falcinellus & & & & & & & & 17 & & 1 & & & 18 \\
\hline Great Blue Heron & Ardea herodias & & & & & 2 & 1 & & 1 & & & & & 4 \\
\hline Great Egret & Ardea albus & 2 & 1 & 5 & 4 & 1 & & 1 & 10 & 1 & & & 2 & 27 \\
\hline Snowy Egret & Egretta thula & & 2 & 6 & 2 & 3 & & & 1 & 1 & & & 1 & 16 \\
\hline Total Count & & 2 & 3 & 11 & 8 & 6 & 1 & 1 & 30 & 2 & 1 & 0 & 3 & 68 \\
\hline Number of Species & & 1 & 2 & 2 & 3 & 3 & 1 & 1 & 5 & 2 & 1 & 0 & 2 & 6 \\
\hline \multicolumn{15}{|l|}{ Raptors } \\
\hline Merlin & Falco columbarius & & 1 & & 1 & & & & 1 & & & & & 3 \\
\hline Northern Harrier & Circus cyaneus & 1 & 4 & & 2 & & & & 1 & & & & & 8 \\
\hline Osprey & Pandion haliaetus & & & & 1 & & & & 6 & & 1 & & 4 & 12 \\
\hline Peregrine Falcon & Falco peregrinus & & & & 1 & & & & & & & & & 1 \\
\hline \begin{tabular}{|l|} 
Total Count \\
\end{tabular} & & 1 & 5 & 0 & 5 & 0 & 0 & 0 & 8 & 0 & 1 & 0 & 4 & 24 \\
\hline Number of Species & & 1 & 2 & 0 & 4 & 0 & 0 & 0 & 3 & 0 & 1 & 0 & 1 & 4 \\
\hline \multicolumn{15}{|l|}{ Shorebirds } \\
\hline Oystercatcher & Haematopus palliatus & & 3 & 4 & 32 & 74 & 3 & 4 & 22 & & 2 & 3 & 7 & 154 \\
\hline Sanderling & Calidris alba & & 5 & & & 4 & & & & & & & & 9 \\
\hline Semipalmated Plover & Charadrius semipalmatus & & 1 & & & 11 & & & & & & & & 12 \\
\hline Semipalmated Sandpiper & Calidris pusilla & & & & & & & & & & & 4 & & 4 \\
\hline Spotted Sandpiper & Actitis macularia & & & & & 1 & & 2 & 10 & & & & & 13 \\
\hline Willet & Tringa semipalmata & & 1 & & 1 & & & & 5 & & 5 & 4 & 3 & 19 \\
\hline Total Count & & 0 & 10 & 4 & 33 & 90 & 3 & 6 & 37 & 0 & 7 & 11 & 10 & 211 \\
\hline Number of Species & & 0 & 4 & 1 & 2 & 4 & 1 & 2 & 3 & 0 & 2 & 3 & 2 & 6 \\
\hline \multicolumn{15}{|l|}{ Gulls and Terns } \\
\hline Black Skimmer & Rynchops niger & & & & & & & & & & & 1 & & 1 \\
\hline Common Tern & Sterna hirundo & & 1 & 1 & 19 & 6 & & & 36 & & 23 & & 6 & 92 \\
\hline Greater Black-backed Gull & Larus marimus & 13 & 47 & 55 & 73 & 212 & 34 & & 3 & & 1 & & & 438 \\
\hline Greater Yellowlegs & Tringa melanoleuca & & & & 2 & 3 & & & & 1 & 1 & 1 & & 8 \\
\hline Herring Gull & Larus argentatus & 172 & 653 & 511 & 1,122 & 2,428 & 410 & 3 & 29 & 6 & 64 & 2 & 4 & 5,404 \\
\hline Laughing Gull & Larus atricilla & & 34 & 120 & 127 & 319 & 79 & 1 & 223 & & 65 & 2 & 48 & 1,018 \\
\hline Ring-billed Gull & Larus delawarensis & 22 & 58 & 44 & 138 & 205 & 37 & & & & & & & 504 \\
\hline Total Count & & 207 & 793 & 731 & 1,481 & 3,173 & 560 & 4 & 291 & 7 & 154 & 6 & 58 & 7,465 \\
\hline Number of Species & & 3 & 5 & 5 & 6 & 6 & 4 & 2 & 4 & 2 & 5 & 4 & 3 & 7 \\
\hline \multicolumn{15}{|l|}{\begin{tabular}{|l|} 
Passerines \\
\end{tabular}} \\
\hline American Crow & Corvus brachyrhynchos & 4 & 8 & & 3 & 2 & 1 & 1 & & & & & & 19 \\
\hline Fish Crow & Corvus ossifragus & 6 & 26 & & 5 & 1 & 3 & 7 & 4 & & 1 & & & 53 \\
\hline Red-winged Blackbird & Agelaius phoeniceus & 2 & 3 & & & & & 7 & 2 & & & 1 & & 15 \\
\hline Song Sparrow & Melospiza melodia & 2 & 1 & & & & & & 2 & & & & & 5 \\
\hline Tree Swallow & Tachycineta bicolor & & 1 & & & & & & & & & & & 1 \\
\hline Yellow-rumped Warbler & Dendroica coronata & 2 & & & & & & & & & & & & 2 \\
\hline Total Count & & 16 & 39 & 0 & 8 & 3 & 4 & 15 & 8 & 0 & 1 & 1 & 0 & 95 \\
\hline Number of Species & & 5 & 5 & 0 & 2 & 2 & 2 & 3 & 3 & 0 & 1 & 1 & 0 & 6 \\
\hline Grand Total Count by Loca & & 249 & 1,330 & 13,671 & 3,048 & 5,776 & 658 & 33 & 526 & 99 & 185 & 24 & 100 & 25,699 \\
\hline Grand Total Number of Spe & cies by Location & 14 & 23 & 15 & 24 & 20 & 11 & 10 & 24 & 10 & 14 & 9 & 9 & 36 \\
\hline
\end{tabular}




\subsection{Water Quality}

Prevailing local water quality conditions can exert a pronounced effect on many of the processes that determine the success of salt marsh restoration efforts (USACE-NYD 2007). Available water quality data from the New York City Department of Environmental Protection's (NYCDEP's) Harbor Water Quality Survey database were downloaded for the nearest Jamaica Bay sampling location (Station J8 shown on Figure 1) and analyzed from 2005 to 2012 for dissolved oxygen, fecal coliform, and Enterococci bacteria, and Secchi depth. Water quality parameters - dissolved oxygen, salinity, and temperature - were also measured from 2005 to 2010 during the nekton monitoring from the top of the sampled water column using a YSI 85 multi-parameter probe.

\subsubsection{Dissolved Oxygen}

The concentration of dissolved oxygen (DO) in the water column is critical for respiration of most aquatic life forms, including fishes and invertebrates, and is, therefore, one of the most widely accepted indicators of overall water quality and a measure of habitat and ecosystem condition (NYCDEP 2015).

On average, Elders East had slightly higher DO concentrations than JoCo Marsh, but at both sites DO typically averaged between 6 and $10 \mathrm{mg} / \mathrm{L}$ during a majority of the sampling events (Table 15). Low DO concentrations $(<3 \mathrm{mg} / \mathrm{L}$ or below the Class D standard in New York state) were observed at JoCo Marsh during the late summer (Event 2) in 2007 and 2008 as well as during both sampling events in 2010 and at the Elders Lower site during the late summer in 2010. Peak average DO concentrations ( $>11 \mathrm{mg} / \mathrm{L}$ ) were recorded at Elders East during the late summer in 2007 and during the early summer (Event 1) in 2008. These results were consistent with the long-term monitoring data recorded by the NYCDEP in Jamaica Bay, which showed a comparable range of DO values and an overall average of $8.2 \mathrm{mg} / \mathrm{L}$ during the 2005 to 2012 monitoring period at Elders East (Figure 15). 
Table 15. Average physical water quality parameters recorded during nekton sampling; Elders Island monitoring sites, $2005-2010$.

\begin{tabular}{|c|c|c|c|c|c|}
\hline \multirow[b]{2}{*}{ Site } & \multirow[b]{2}{*}{ Event } & \multirow[b]{2}{*}{ Year } & Average Temperature & $\begin{array}{c}\text { Average Dissolved } \\
\text { Oxygen }\end{array}$ & Average Salinity \\
\hline & & & $\left({ }^{\circ} \mathrm{C}\right)$ & $(\mathrm{mg} / \mathrm{L})$ & (ppt) \\
\hline \multirow{12}{*}{ Elders East } & \multirow{6}{*}{1} & 2005 & 28.1 & 10.2 & 25.9 \\
\hline & & 2006 & 23.9 & 6.5 & 26.2 \\
\hline & & 2007 & 24.5 & 3.7 & 26.1 \\
\hline & & 2008 & 29.6 & 14.8 & 26.0 \\
\hline & & 2009 & 24.3 & 7.4 & 22.7 \\
\hline & & 2010 & 26.5 & 4.2 & 22.1 \\
\hline & \multirow{6}{*}{2} & 2005 & 21.8 & 9.8 & 26.9 \\
\hline & & 2006 & 21.2 & 8.9 & 26.1 \\
\hline & & 2007 & 28.7 & 12.8 & 26.7 \\
\hline & & 2008 & 27.9 & 11.2 & 26.8 \\
\hline & & 2009 & 25.6 & 6.2 & 23.3 \\
\hline & & 2010 & 31.0 & 10.7 & 27.3 \\
\hline \multirow{8}{*}{ Elders Lower } & \multirow{4}{*}{1} & 2007 & 23.1 & 7.3 & 26.5 \\
\hline & & 2008 & 29.9 & 6.6 & 27.3 \\
\hline & & 2009 & 27.5 & 10.9 & 23.7 \\
\hline & & 2010 & 26.3 & 4.7 & 25.8 \\
\hline & \multirow{4}{*}{2} & 2007 & 25.4 & 6.1 & 27.0 \\
\hline & & 2008 & 28.4 & 6.8 & 27.0 \\
\hline & & 2009 & 27.8 & 6.0 & 24.1 \\
\hline & & 2010 & 24.8 & 1.2 & 27.7 \\
\hline \multirow{12}{*}{ JoCo } & \multirow{6}{*}{1} & 2005 & 29.5 & 4.4 & 25.7 \\
\hline & & 2006 & 26.8 & 6.2 & 27.7 \\
\hline & & 2007 & 27.2 & 7.4 & 24.1 \\
\hline & & 2008 & 28.5 & 7.2 & 28.4 \\
\hline & & 2009 & 26.5 & 7.5 & 24.9 \\
\hline & & 2010 & 27.5 & 2.4 & 25.8 \\
\hline & \multirow{6}{*}{2} & 2005 & 26.6 & 6.7 & 25.2 \\
\hline & & 2006 & 22.3 & 7.0 & 26.0 \\
\hline & & 2007 & 22.8 & 1.9 & 25.8 \\
\hline & & 2008 & 21.1 & 2.8 & 23.0 \\
\hline & & 2009 & 28.2 & 7.9 & 21.9 \\
\hline & & 2010 & 27.7 & 2.4 & 28.6 \\
\hline
\end{tabular}


Figure 15. Dissolved oxygen $(\mathrm{mg} / \mathrm{L})$ measured during NYCDEP harbor quality survey at Station J8 (40.642833 N, 73.851167 W) near Elders Point East Site, 2005 - 2012.

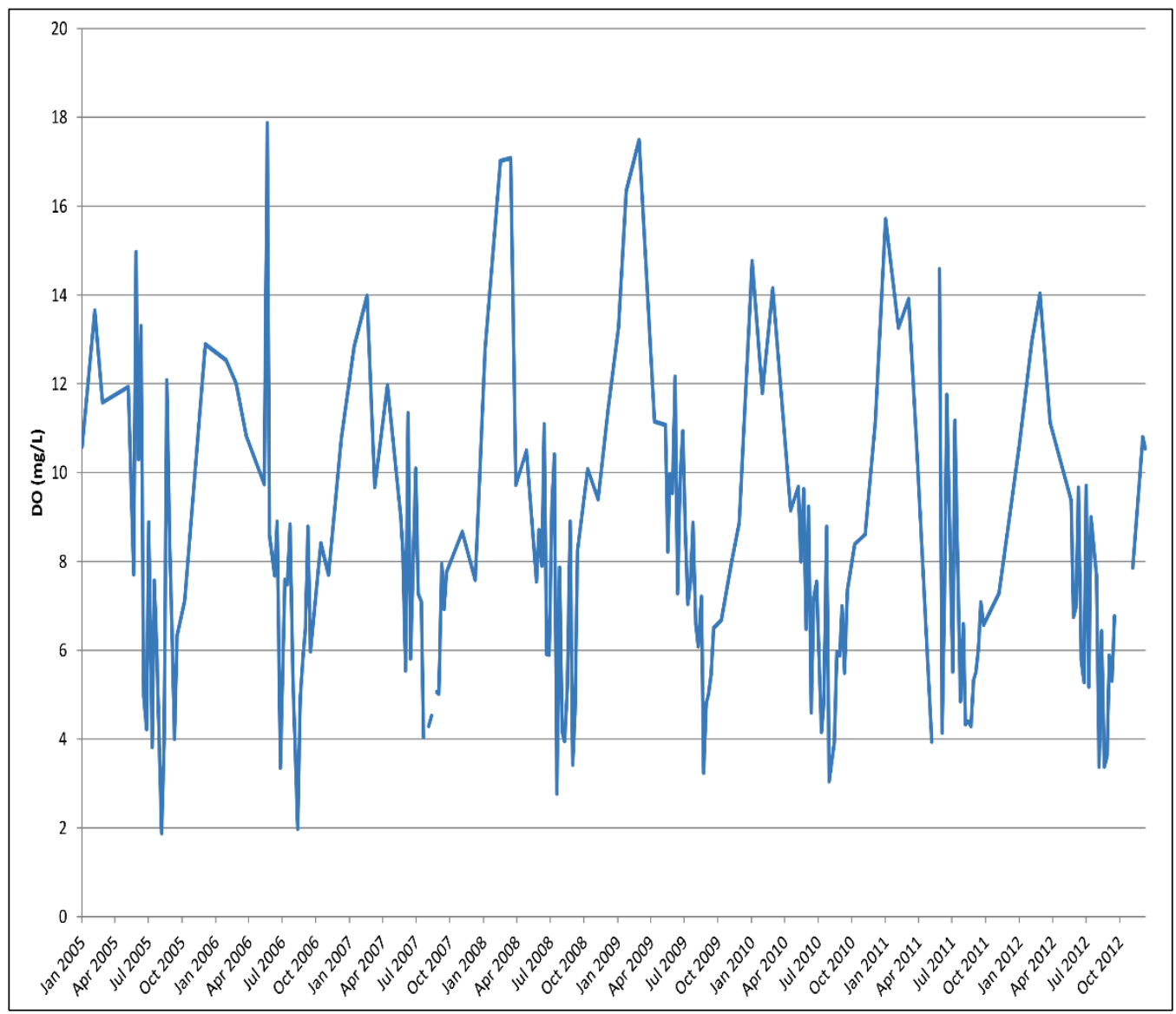

\subsubsection{Salinity}

Water salinity on average was comparable between the Elders East, Elders Lower, and JoCo Marsh sites, and typically ranged between 25 and 27 parts per thousand (ppt) (Table 15). Sampling event variations were likely driven by tidal cycle conditions and freshwater inputs during the sampling with the lowest salinities on average recorded at all three sites in 2009 and comparatively higher salinities recorded in 2010.

\subsubsection{Temperature}

Average water temperature sampled at the Elders East restoration sites typically ranged from 21 to $29^{\circ} \mathrm{C}$. Generally higher water temperatures were recorded during the early summer events, except for in 2007 at the Elders East sites, at all three sites in 2009, and all but Elders Lower in 2010 (Table 15). The highest average water temperature of $31.0^{\circ} \mathrm{C}$ was recorded at Elders East during the late summer in 2010 and the lowest of $21.1^{\circ} \mathrm{C}$ was recorded at JoCo Marsh during the late summer sampling in 2008. 


\subsubsection{Secchi Depth}

A Secchi disk was used to estimate the clarity of surface waters during the NYCDEP surveys of harbor water quality. High Secchi depth (greater than 5.0 feet) is indicative of clear water while low Secchi readings (less than 3.o feet) are typically associated with degraded waters. Declines in transparency are typically due to high suspended solids concentrations or plankton blooms and are indicative of light-limiting conditions, which in turn affect primary productivity and nutrient cycling (NYCDEP 2015).

Figure 16 presents the long-term monitoring data for Secchi depth recorded by the NYCDEP in Jamaica Bay from 2005 to 2012. Secchi depth typically ranged between 2 and $6 \mathrm{ft}$, with an average of $4.0 \mathrm{ft}$ during the monitoring period at Elders East, suggesting moderate turbidity conditions on average in Jamaica Bay in the project area.

\subsubsection{Fecal Coliform and Enterococci Bacteria}

Fecal coliforms are a group of bacteria primarily found in human and animal intestines and are associated with sewage-related pollution. These bacteria are widely used as indicator organisms to indicate the presence or absence of such wastes in surface waters (NYCDEP 2015). Enterococci bacteria are a subgroup within the fecal Streptococcus group and are distinguished by their ability to survive in salt water. This subgroup is typically more human-specific than the larger fecal Streptococcus group and is therefore a widely used indicator of health risk in salt water used for recreation (NYCDEP 2015).

Figures 17 and 18 present the long-term monitoring data for fecal coliform and Enterococcus, respectively, recorded by the NYCDEP in Jamaica Bay from 2005 to 2012. Fecal coliform counts were typically less than 500 per $100 \mathrm{~mL}$, but reached peaks of greater than 2,000 in September 2011 (5,900 per $100 \mathrm{~mL})$, June 2012 (16,100 per $100 \mathrm{~mL})$, and August 2012 $(5,100$ per $100 \mathrm{~mL})$.

Enterococcus counts were typically less than 10 per $100 \mathrm{~mL}$, but reached peaks of greater than 300 in June 2009 (1,500 per $100 \mathrm{~mL})$, July 2009 (580 per $100 \mathrm{~mL}$ ), May 2011 (1,660 per $100 \mathrm{~mL}$ ), and June 2012 (420 per $100 \mathrm{~mL}$ ). The latter event also coincided to the peak in fecal coliform count observed in June 2012. 
Figure 16. Secchi transparency (ft.) measured during NYCDEP harbor quality survey at Station J8 (40.642833 N, 73.851167 W) near Elders Point East Site, 2005 - 2012.

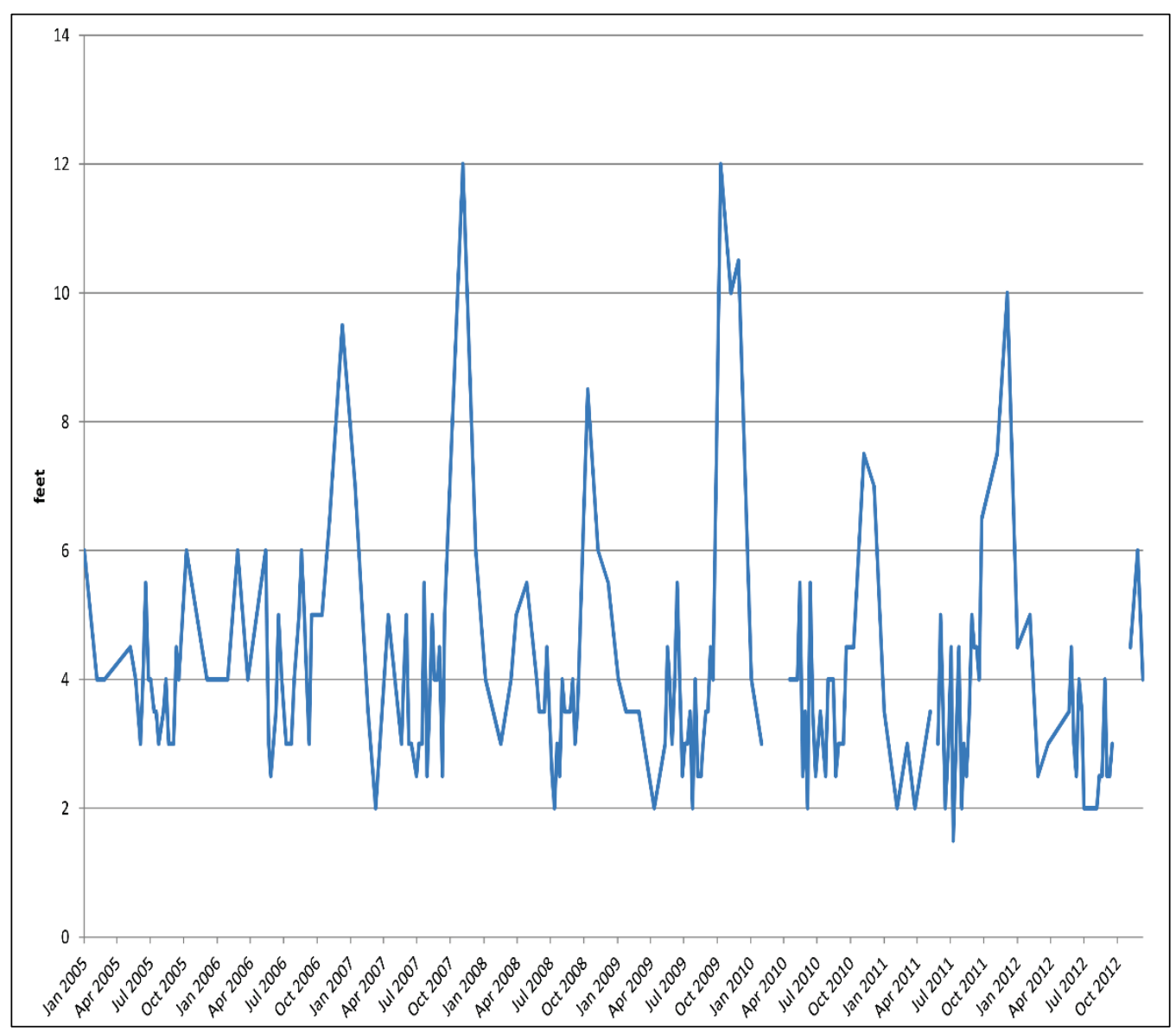


Figure 17. Fecal coliform count (\#/100 mL) measured during NYCDEP harbor quality survey at Station J8 (40.642833 N, 73.851167 W) near Elders Point East Site, 2005 - 2012.

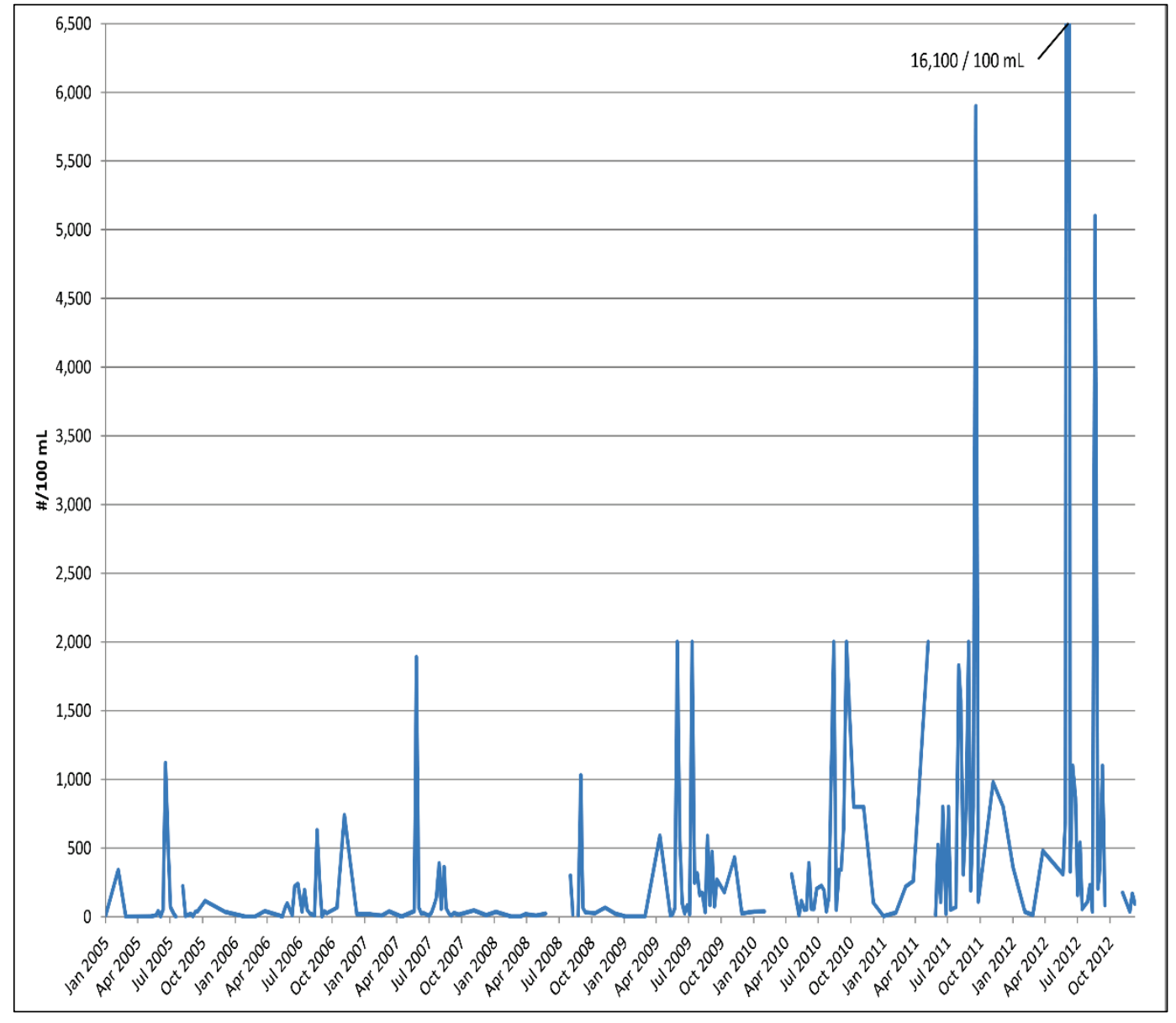


Figure 18. Enterococcus count (\#/100 mL) measured during NYCDEP harbor quality survey at Station J8 (40.642833 N, 73.851167 W) near Elders Point East Site, 2005 - 2012.

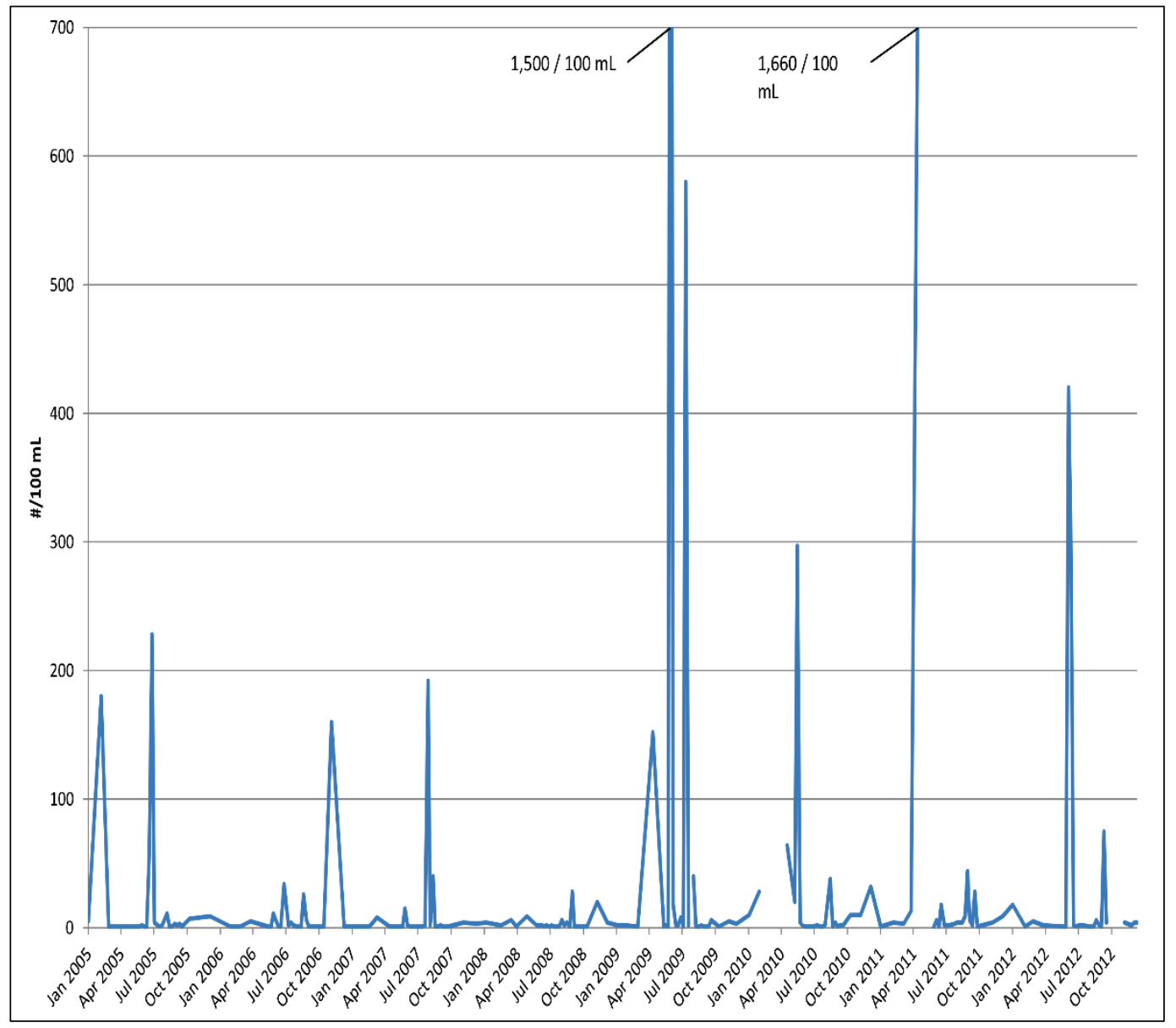




\section{Summary}

Substantial losses of salt marsh habitat over wide geographical areas were recognized decades ago, leading to research into a range of options for restoration efforts (Broome et al. 1988). An extensive historical record of beneficial use of dredged material projects intended to restore salt marsh restoration exists, extending over a span of several decades. Initially these projects were concentrated in the Gulf of Mexico and southeast Atlantic regions (e.g., LaSalle et al. 1991; Shafer and Streever 2000), but eventually extended into the northeast Atlantic region (e.g., Yozzo et al. 2004; Teal and Weishar 2005). Consequently, the science of salt marsh restoration involving placement of dredged material has received a great deal of attention. Some debate persists about the degree to which dredged material marshes emulate functional attributes of natural marshes (Streever 2000). Regardless, in cases where marsh loss rates are high, the general consensus among restoration practitioners is that placement of dredged material by various means represents one of few available options for sustaining salt marsh habitat (Ford et al. 1999; Mendelssohn and Kuhn 2003).

Over the past two decades, a scientific consensus has emerged that the fragile marsh island ecosystem within Jamaica Bay is disappearing at an alarming rate (Wigand et al. 2014). Some estimates have projected the total loss of marsh habitat within the next two decades (GNRA and JBWPPAC 2007). The Jamaica Bay marshes provide critical habitat for fish and crustacean species, migratory birds and waterfowl, and a number of managed species. Jamaica Bay's marshes also form a first line of defense against surges and flooding during coastal storms such as Hurricane Sandy, which devastated the region in October 2012. Ironically, Sandy's arrival coincided with the end of the long-term monitoring of the wetland restoration project at Elders Point East Marsh. Post Sandy studies of the Jamaica Bay marsh island system, including the Elders Point East restoration site, offer the opportunity to evaluate (among other things) the efficacy of marsh islands for wave attenuation and the protection of coastal communities. In a literature review of recent wave attenuation data, Gedan et al. (2011) found ample evidence from modeling, observational, and field studies that coastal wetlands protect shorelines from erosion and wave damage in a variety of direct and indirect ways that slow water flow, facilitate sediment deposition, increase shoreline cohesion, and build peat.

The pre- and post-restoration monitoring protocols and the adaptive management plan defined in USACE-NYD (2007) provided an objective 
methodology to assess the biological effectiveness of the restoration at Elders East and to provide the basis for comparing the restoration site with the JoCo Marsh reference site. Specifically, monitoring was designed to examine "trajectories" of selected ecological functions anticipated to be provided by the completed restoration site. In theory, the restoration efforts would eventually result in a suite of ecological marsh attributes typical of a healthy "reference" system (Mitsch and Wilson 1996, Mitsch et al. 1998). Thus, the restoration work at Elders Point East and later in 2010, Elders West, not only offered the immediate benefit of the creation of 32.4 ha (8o acres) of marsh island habitat but also provided the additional opportunity to study and evaluate various planting techniques, justify adaptive management actions, and to better understand factors contributing to short- and long-term wetland loss throughout Jamaica Bay (Rafferty et al. 2010).

\subsection{Hydrology and Sediment Movement Processes}

Although the causes of tidal wetland loss are site-specific and often poorly understood, Hartig et al. (2002) suggested that increased ponding within marsh interiors, slumping along marsh edges, and the widening of tidal inlets may be contributing to the loss of Jamaica Bay's marshes through a process of undercutting and collapse of belowground organic matter (peat) along the perimeter of the islands. Belowground biomass production may contribute substantially to the elevation of marsh substrate (Connor and Chmura 2000) and thus, without sufficient accumulation and with diminished root production, a marsh that exhibits high aboveground biomass may quickly convert to open water rather than revegetate (DeLaune et al. 1994). The hydrology of a tidal marsh (i.e., the frequency, depth, and duration of inundation) is therefore critical to its establishment and long-term success and may be influenced or altered by changes in sea level rise, tidal range, and changes in the rate of accretion and subsidence (Morris et al. 2002).

Baseline sediment elevation data were collected in 2007 and follow-on data were collected in 2009 and 2010 at Elders East. Data collection focused on the perimeter of the island, where it was anticipated that sediment transport would be most active and was spaced to allow for the post-processing development of a digital elevation model (DEM). Observed patterns of sediment elevation change (erosion and deposition) from 2007 to 2009 revealed net losses along the western shore (typically between 0.25 and 1.0 feet $(0.3 \mathrm{~m})$ ) and net gains (up to 1.0 feet $(0.3 \mathrm{~m})$ ) primarily in the northeast corner and south-central portions of the island. The changes were 
assumed to be consequences of the tidal energy and geophysical forces acting upon the marsh island. Results of a preliminary settlement analysis (USACE-NYD 2008) indicated that after the Elders East restoration work took place, there was a period of settlement. Around the perimeter of the island, the -2 foot NAVD 88 elevation contour generally moved outward toward the northeast. This was consistent with the prevailing wind direction. The zero elevation contour was stable, which suggested that the island was not changing shape or moving. The upland 2.25 and 1.5 contours moved inward, suggesting some settlement of the island onto itself or possibly due to wave action pushing material up the banks.

Overall, there appears to be morphologic stability with the placed material at Elders East. This was evident in the results of the post construction monitoring, which determined that the majority of the placed material remained in stable deposits. This overall result could have major implications for the sustainability of benefits of present and future restoration and mitigation efforts in Jamaica Bay.

\subsection{Vegetation}

Results of the post-construction monitoring for vegetative parameters indicate that the restoration trajectory at Elders East has approached the condition of the JoCo Marsh reference wetland for the select biotic attributes/ecological functions evaluated and has reached equivalence with respect to vegetative structural attributes, including total canopy coverage, stem density, plant height, and total standing aboveground biomass. The rapid convergence of these attributes of the restored salt marsh (within two full growing seasons for most) with those of the reference site provides evidence to support the conclusion of restored tidal hydrology, suitable substrate, and appropriate vegetation species at the restoration site.

Results of the vegetative data analyses indicate relatively stable plant cover of between 50 and $70 \%$ at the JoCo Marsh reference site. Also, low interannual variability of the importance value of the dominant species at JoCo Marsh supports an observation that a mature and diverse salt marsh community exists at JoCo. In comparison, Elders East underwent a steady increase in percent cover from the pre-restoration condition to a peak of $71 \%$ cover in 2008 , followed by a plateau between approximately 40 and $50 \%$ for the remainder of the study period, or approximately $10 \%$ below observed reference conditions during the same period (2009 to 2012). When plotted as percent change in total cover for each individual plot 
(Figure 19), this pattern of initial increases in vegetative coverage from 2006 to 2008 at Elders East, followed by decreased canopy coverage between 2008 and 2012, is apparent at each of the treatment locations. Moreover, complete loss of the plantings can be noted along the perimeter of the island by 2012 (Figure 19). By 2010 and 2012, however, no significant difference in total percent plant cover was noted between Elders East and JoCo Marsh, suggesting that any pattern of change in vegetative cover was also occurring in other areas of Jamaica Bay at the end of the monitoring period.

Other growth measurements, such as stem density and plant height of Spartina alterniflora, followed a positive trend at Elders East. Species richness increased steadily each year during the monitoring from three species during prerestoration and restoration construction (2005 to 2007) to a high of nine species in 2012. This trend was repeated for both Margalef's Diversity and Simpson's Heterogeneity values, providing further evidence that the Elders East marsh was maturing steadily over the course of the monitoring program.

The early development of aboveground standing biomass was slow at Elders East. However, after the first year of establishment, aboveground biomass increased dramatically to approximate observed reference conditions (800 and $1,200 \mathrm{~g} / \mathrm{m}^{2}$ ) from 2008 to 2010 such that no significant difference was noted between the restored and reference marshes from 2009 to 2012. Both Elders East and JoCo Marsh showed similar slight declines in aboveground biomass between 2010 and 2012. The range of aboveground biomass values at Elders East was comparable to other successful salt marsh restoration projects along the U.S. Atlantic coast, including a restoration project following a fuel oil spill along the Arthur Kill on Staten Island, New York. At that site, Bergen et al. (2000) reported aboveground biomass values between 335 and 2,144 g/m². A nearby study, located at a salt marsh slated for restoration upstream of the confluence of Woodbridge Creek and the Arthur Kill, in Woodbridge, New Jersey reported an average aboveground Spartina alterniflora biomass value of $750 \mathrm{~g} / \mathrm{m}^{2}$ (Sturdevant et al. 2002). Following restoration (3-5 years postconstruction), mean Spartina alterniflora biomass values ranged from 1,450 to $1,550 \mathrm{~g} / \mathrm{m}^{2}$ (Henningson 2014). In one of the earliest long-term monitoring studies of constructed salt marshes along the U.S. Atlantic coast, Broome et al. (1986) reported an average biomass value of $1,130 \mathrm{~g} / \mathrm{m}^{2}$ for restored Spartina alterniflora stands near Pine Knoll Shores, North Carolina. 


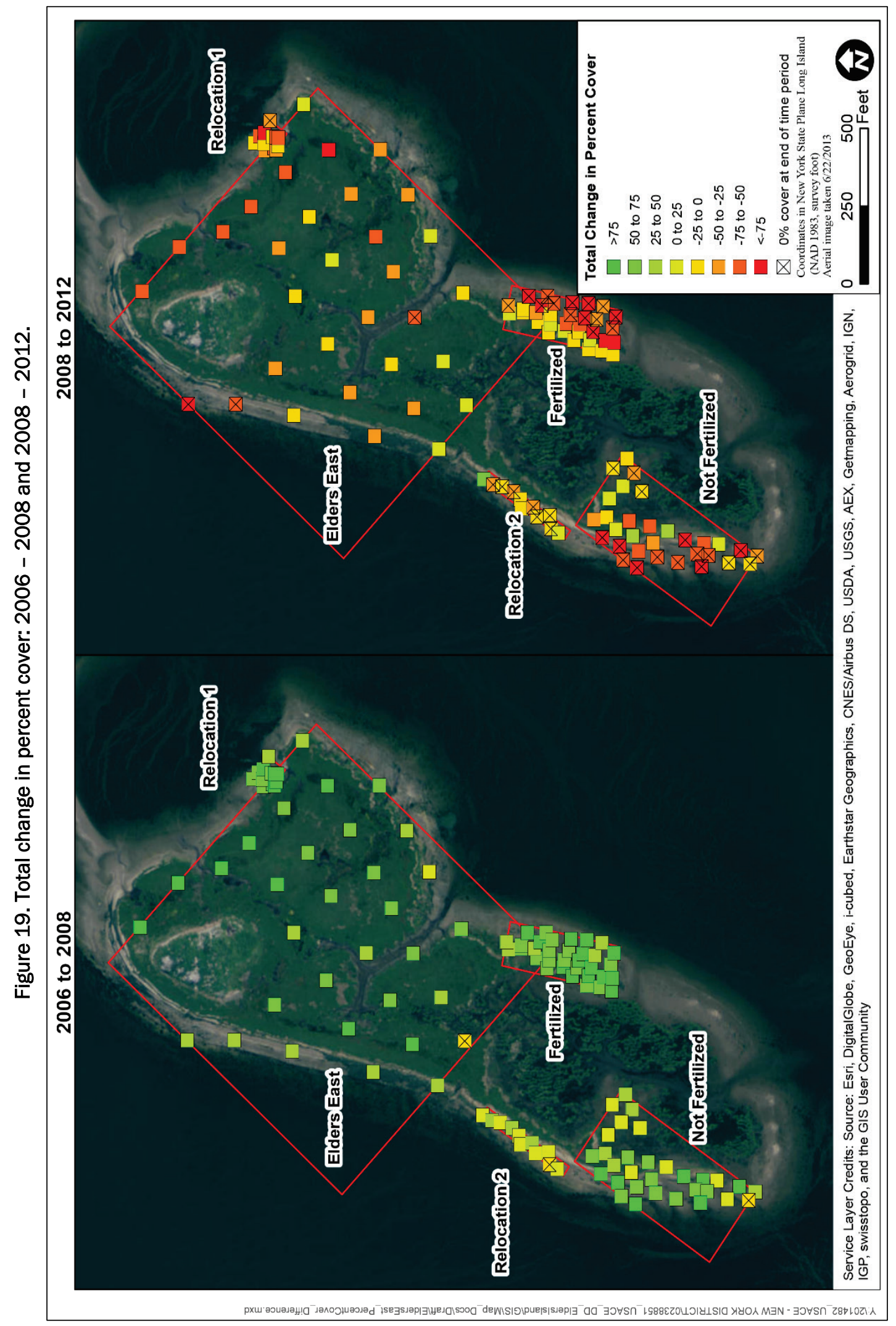


Tidal saltmarshes have long been recognized for their high rates of primary aboveground biomass production, although belowground biomass may play an even more critical role in establishing and maintaining sediment elevation (Connor and Chmura 2000). During the establishment period of the restoration marsh from 2008 to 2012, total belowground biomass at Elder East was approximately one fourth that of the JoCo reference marsh on average. However, total belowground biomass during this period consistently measured approximately $2,500 \mathrm{~g} / \mathrm{m}^{2}$ on average each year and was comparable to the other restoration marshes referenced above. Overall, the deeper $15-30 \mathrm{~cm}$ interval accounted for approximately 20-25\% of the total belowground biomass at Elders East from 2008 to 2012. During this period, the biomass ratio at Elders East fluctuated around 1:2 ratio in favor of belowground biomass before decreasing in 2012 to approximately 1:5, which was closer to the ratios found at the JoCo reference site, another indication that Elders East was developing into a stable salt marsh similar to the JoCo Marsh.

The restoration and monitoring design at Elders East allowed for the evaluation of other restoration scenarios, within an adaptive management framework; specifically, the comparison of a fertilizer versus no fertilizer treatment and the evaluation of a relocation method that conserved existing marsh vegetation from a nearby site. This latter treatment, which involved the relocation of approximately 0.6 ha (1.5 acres) of existing smooth cordgrass hummocks, was noted by project biologists to require an additional year to achieve 50\% canopy cover compared to the new planted treatment at Elders East; however, by 2009, there was no difference in canopy cover or vegetation species composition, richness, and diversity between the two treatments (Rafferty et al. 2010).

The response of the fertilizer treatment suggests that a temporary benefit is accrued for certain growth measures such as total canopy cover and stem density; however, benefits for above- and belowground biomass, a critical component of marsh island establishment, were not apparent. Total vegetative cover, for example, was approximately 10-20\% less in each year at the No Fertilizer site when compared to the Fertilizer treatment but no significant difference $(p>0.05)$ between the treatments was detected in 2010 and 2012. After the initial plantings in 2007, the Fertilizer site on average presented slightly higher above and belowground biomasses in 2008 and 2009. In 2010, the No Fertilizer treatment yielded comparable aboveground biomass to the Fertilizer treatment, but had more than twice 
the average belowground biomass in the deep 15-30 inch layer. However, by 2012, the Fertilizer treatment again resulted in higher aboveground and belowground biomass when compared to the No Fertilizer site. A significant difference $(p<0.05)$ in aboveground biomass was only noted in 2007 between the two treatments. No significant differences ( $p>0.05)$ in belowground biomass at either depth interval were detected between the treatments.

\subsection{Other Biological and Physical Measures}

To provide an objective assessment of the potential biological changes resulting from the restoration, a number of additional avian, benthic macro-invertebrate, nekton, and water quality studies were conducted in parallel at Elders East and the JoCo reference location. The Jamaica Bay marsh islands provide critical habitat for birds as well as for both benthic (sediment dwelling) and nektonic (free-swimming) organisms, which, in turn, represent a significant food resource for fish, birds and marine mammals. Moreover, the benthic and nektonic communities often respond quickly to environmental changes, both natural and human-induced, and therefore can be useful indicators during estuarine monitoring programs (USACE-NYD 2007).

A number of benthic and nektonic community indices were evaluated, including taxa richness, density, and community diversity and evenness. A general pattern emerged within the benthic community analysis suggesting a relatively stable benthic community from year to year at the JoCo reference marsh. In comparison, the Elders East restoration site tended to score low on the various benthic community indices from 2005 to 2007 before increasing to similar and sometimes even higher benthic values as the restoration matured. This observation is consistent with previous observations at restored salt marshes (Craft 2000, Craft et al. 2003, Sacco et al. 1994). For example, taxa richness was consistently between 11 and 15 taxa in all sampling years at JoCo Marsh compared to Elders East, which trended towards higher taxa richness as the restoration matured, reaching a peak of 17 different taxa in 2009 and high community diversity in that same year. These results indicated that the Elders East restoration site was capable of producing and maintaining a characteristic, productive benthic community.

One notable outcome of the benthic and nekton community composition analysis was that no horseshoe crabs were collected at JoCo Marsh. 
Horseshoe crabs were collected consistently in most years at Elders East, beginning in 2008 , and represented $52 \%$ and $19 \%$ of the total collected during the benthic and nekton sampling, respectively. Horseshoe crabs are a unique marine invertebrate widely distributed along the Atlantic Coast, but are most abundant from Virginia to New Jersey. Adult horseshoe crabs winter in deep coastal waters (20 to $60 \mathrm{ft}$ ) and on the continental shelf (Walls et al. 2002). As temperatures warm and daylight increases, adults migrate inshore where they feed predominately on bivalve mollusks and spawn during May and June on sandy beaches in bays and coves protected from heavy wave action (USACE-NYD 2007). The common occurrence of horseshoe crabs at Elders East compared to JoCo Marsh perhaps could be a reflection of their preference for sandy habitats and the high sand content ( $>95 \%$ ) at the restoration sites but nonetheless could be a topic of interest for further investigation as the restoration site matures.

Length frequency data from the nekton sampling demonstrated that the newly restored Elders East marsh provides nursery habitat for horseshoe crabs as the vast majority of the horseshoe crabs collected at Elders East were newly hatched young-of-the-year. In addition, the nekton sampling confirmed that the restored Elders East marsh provided nursery habitat for a variety of other juvenile fishes, including Atlantic silversides, mummichogs, and other killifish species that in turn provide important forage for predatory fishes and birds.

One of the more critical functions provided by the restored Elders East marsh is provision of habitat for resident and migrating birds. Systematic and opportunistic observations recorded at both Elders East and JoCo Marsh from 2006 to 2010 provided a database of more than 25,000 bird counts representing 36 species. Proportionally more birds were observed at Elders East compared to JoCo Marsh, especially in 2006 and 2007 during the restoration construction when $27 \%$ and $59 \%$ of the surveyed birds were recorded, respectively. The majority of the birds observed at Elders East in 2006 and 2007 were Brant, but species richness was also highest at Elders East during 2006 and 2007 (24 and 22 different species observed, respectively). The fewest birds and species at Elders East were observed in the first year of post-construction monitoring (2008) despite the highest number of surveys (20), but rebounded to pre-construction levels in 2009. Seasonal trends in species occurrence were also apparent, including the fall and winter, when most of the waterfowl species were common. 
With respect to water quality, Elders East had slightly higher dissolved oxygen concentrations than JoCo, but at both sites dissolved oxygen typically averaged between 6 and $10 \mathrm{mg} / \mathrm{L}$. Periodic lows and highs were comparable to the range of dissolved oxygen and overall average of $8.2 \mathrm{mg} / \mathrm{L}$ from 2005 to 2012, as indicated in the NYCDEP long-term monitoring dataset. Both recorded salinity and temperatures from the nekton sampling were within the ranges expected for a coastal temperate estuary. Secchi depth data from the NYCDEP monitoring program typically ranged between 2 and $6 \mathrm{ft}$ with an average of $4.0 \mathrm{ft}$, suggesting generally moderate turbidity conditions on average in Jamaica Bay in the area of the restoration. Both Fecal coliform and Enterococcus data from NYCDEP showed occasional spikes in Jamaica Bay, possibly reflecting the presence of sewage-related pollution in surface waters near the restoration site. 


\section{Long-Range Future Recommendations}

USACE, the NPS, and several other stakeholders collaborated to implement standardized research, monitoring, and adaptive management protocols for evaluating the success of various restoration techniques and for investigating the fundamental causes of salt marsh loss in Jamaica Bay, New York. The goal of these monitoring protocols was to provide an objective assessment of the relative success of the salt marsh restoration project.

The return on investment in monitoring activities can best be maximized by adaptively examining lessons learned during the course of the project, and sharing that information with stakeholders engaged in similar projects. In the present project, knowledge was gained concerning effective logistical measures and management strategies. A finding of overall success of the project, justified by the results of monitoring of a suite of relevant environmental parameters, must be viewed in a long-term, ecosystem development context. Multi-year monitoring of the performance of important indicators of intertidal wetland processes has provided strong evidence that restoration efforts, when properly designed and executed, can indeed restore critical ecological functions in Jamaica Bay.

One important consideration is the definition of "long-term." For the Elders East Project, multiple years of post-construction monitoring certainly adds confidence to a finding of success. However, the ultimate success of these restoration efforts will hinge upon processes that may be operating on decadal time scales. Persistence of the placed material and plantings following passage of at least one significant coastal storm does indicate stability and some degree of resilience of the restored habitat. Attainment of a new equilibrium with respect to sediment transport processes may also require extended "long-term" monitoring to truly assess overall project success. One recommendation for future restoration projects in Jamaica Bay or elsewhere would be awareness of the time scales involved for attainment of physical and biological functions, and the need for resource agencies and other stakeholders to commit management strategies to appropriate time scales. For example, three years have elapsed since the completion of monitoring efforts at Elders East. This may represent a sufficient time interval to repeat the original aerial photography, reassess the geomorphological stability of the restored site, 
repeat the vegetation analysis, and/or derive estimates of net sediment accretion or loss.

The monitoring program ultimately provided the foundation for evaluating the degree to which ecological function was reestablished in the restored intertidal marsh component of the estuarine landscape. In conjunction with evaluating the functional equivalency trajectory toward the reference condition, the restoration site can be compared with the original construction plans and specifications. If the restoration site compares favorably with the plans and specifications during the monitoring period, the restoration site will achieve project goals and objectives over time including the fulfillment of permit requirements. Allowances are always needed to accommodate natural succession and variability. Any reference marsh - JoCo Marsh in this case - represents a dynamic system undergoing seasonal and interannual variation in response to natural and anthropogenic forcing factors. Consequently, an expectation that the restored marsh habitat would provide a "mirror image" in terms of physical and biological attributes is unreasonable. Nevertheless, the Elders East project has clearly demonstrated that properly executed beneficial use of dredged material offers a viable approach to intertidal marsh restoration within Jamaica Bay.

Comparisons of dredged material and natural marshes by Shafer and Streever (2000) for restoration projects in Texas revealed a number of factors that contributed to functional differences. One key factor was the edge:area ratio exhibited by the two marsh types. Natural marshes consisted of considerably higher amounts of edge habitat per unit area. In particular, the presence of drainage channel networks into the interior of natural marshes provided greater access to marsh surfaces for fishes and crustaceans. They also observed the extended duration required by marsh plants to develop mature root systems as evidenced by belowground biomass. The Texas marshes were not necessarily directly comparable to the Elders East Marsh, in that dredged materials used in Texas consisted of high fractions of silts and clays as well as high sediment organic content.

In the case of Elders East, relative success should be gaged in light of past experiences with using dredged material as a substrate for marsh restoration. In Streever's 2000 review, he concluded that after sufficient post-construction time, differences between dredged material and natural marshes were minor in terms of vegetation stem densities, oligochaete 
densities, and fish utilization. However, other parameters - including aboveground and belowground plant biomass, organic carbon content, and polychaete and crustacean densities - differed in at least subtle degrees. Likewise, bird use of dredged material marshes differed from that in natural marshes. Overall, Streever (2000) concluded that dredged material marshes were effective replacements for some - but not all - ecological functions of natural marshes. The definition of success for Elders East and similar restoration projects should therefore acknowledge the fact that a perfect match with a natural reference marsh may not be achievable.

Success can be defined by the similarity of selected metrics (physical and biological), or "performance indicators" between the reference and restored sites. An inherent assumption is that these metrics accurately represent the functions and values intrinsic in a productive salt marsh. The undertaking of tidal salt marsh restoration projects on the scale accomplished at Elders East provided a unique opportunity to measure and assess the success of large-scale restoration efforts in the greater New York coastal region. Rafferty et al. (2010) conclude that a principal success of the Jamaica Bay marsh restoration has been the development of a strong multi-agency partnership that is working to implement and monitor marsh restoration by advancing the current understanding of plant community dynamics and stability as related to marsh loss.

In summary, most indications are that several years after placement of dredged materials and other fill, the Elders East marsh is functioning as valuable marsh habitat in the Jamaica Bay ecosystem. Although complexities in making direct comparisons between Elders East and the reference marsh preclude a finding of full equivalence, the levels of ecological function observed to date are encouraging. Certainly in terms of stemming marsh loss, this project has demonstrated a viable means to sustain habitat over appreciable time. Results should prove valuable in long-term management of restoration efforts throughout the ecosystem. For example, if monitoring revealed an eventual net loss of restored habitat, "renourishment" efforts could be planned in advance. In order to optimize accrued habitat benefits, further investigation of the feasibility of incorporating access channels mimicking natural marshes could be considered. Adaptive management should also include integration of costeffective practices to enhance success. For example, application of fertilizer treatments may provide only temporary, small-scale benefits, 
whereas effective use of fencing to reduce grazing by geese may actually afford substantial long-term savings per habitat unit restored.

To prevent continued loss of the Jamaica Bay marsh islands, decisive action must be taken by placing emphasis on improving mitigation compliance, generating desired acreages, and maintaining a true baseline for future restoration/mitigation efforts. Race and Fonseca (1996) and Roberts (1993) have noted that the overall success rate of past permitlinked mitigation projects remains low and subject to a high degree of failure nationwide. Reporting and actively disseminating the results of the tidal salt marsh restoration projects in Jamaica Bay may therefore be pivotal for establishing a benchmark for achieving success on future largescale wetland restoration efforts in Jamaica Bay and elsewhere. 


\section{References}

Able, K. W. and M. P Fahay. 2010. Ecology of estuarine fishes - temperate waters of the Western North Atlantic. Baltimore, MD: The John Hopkins University Press.

Bergen, A., C. Alderson, R. Bergfors, C. Aquila and M. A. Matsil. 200o. Restoration of a Spartina alterniflora salt marsh following a fuel spill. New York City, NY. Wetland Ecology and Management 8:185-195.

Broome, S. W., E. D. Seneca, and W. W. Woodhouse, Jr. 1986. Long term growth and development of transplants of the salt marsh grass S. alterniflora. Estuaries 9:63-74.

Broome, S. W., E. D. Seneca, and W. W. Woodhouse, Jr. 1988. Tidal salt marsh restoration. Aquatic Botany 32(1-2):1-22.

Brower, J. E., J. H. Zar, C. N. von Ende. 1997. Field and laboratory methods for general ecology, 4th ed. Boston, MA: WCB McGraw-Hill.

Clarke, K. R. and R. M. Warwick. 2001. Change in Marine Communities: An Approach to Statistical Analysis and Interpretation. Second Edition. Primer-E Ltd. Plymouth Marine Laboratory, U.K.

Connor, R. and G. L. Chmura. 2000. Dynamics of above- and belowground organic matter in a high latitude macrotidal saltmarsh. Marine Ecology Progress Series: Volume 204: 101-110.

Craft, C. B. 2000. Co-development of wetlands soils and benthic invertebrate communities following salt marsh creation. Wetlands Ecology and Management 8:197-207.

Craft, C., P. Megonigal, S. Broome, J. Stevenson, R. Freese, J. Cornell, L. Zheng and J. Sacco. 2003. The Pace of ecosystem development of constructed Spartina alterniflora marshes. Ecological Applications 13:1417-1432.

Cristini, A. 1991. Synthesis of information on the distribution of benthic invertebrates in the hudson/raritan system. Final Report. Mahwah, NJ: Ramapo College of New Jersey.

Dauer, D. M. 1993. Biological criteria, environmental health and estuarine macrobenthic Community structure. Marine Pollution Bulletin 26:149-157.

DeLaune, R. D., J. A. Nyman, and W. H. Patrick, Jr. 1994. Peat collapse, ponding and wetland loss in a rapidly submerging coastal marsh. Journal of Coastal Research 10(4): 1021-1030.

Ford, M. A., D. R. Cahoon, and J. C. Lynch. 1999. Restoring marsh elevation in a rapidly subsiding saltmarsh by thin-layer deposition of dredged material. Ecological Engineering 12(3-4):189-205. 
Gateway National Recreation Area (GNRA) \& Jamaica Bay Watershed Protection Plan Advisory Committee (JBWPPAC). 2007. An Update on the Disappearing Salt Marshes of Jamaica Bay, New York.

Gedan, K. B., M. L. Kirwan, E. Wolanski, E. B. Barbier and B. R. Silliman. 2011. The present and future role of coastal wetland vegetation in protecting shorelines: answering recent challenges to the paradigm. Climatic Change (2011) 106:7-29.

Hartig, E. K., V. Gornitz, A. Kolker, F. Mushacke, and D. Fallon. 2002. Anthropogenic and climate-change impacts on salt marshes of Jamaica Bay, New York City. Wetlands 22(1):71-89.

Henningson, Durham and Richardson Architecture and Engineering, P.C./HDR Engineering, Inc. (HDR). 2014. Woodbridge Creek Salt Marsh Restoration, PostRestoration Monitoring - Final Report to NOAA-NMFS. Pearl River, NY.

Hettler, W. F. 1989. Nekton use of regularly-flooded saltmarsh cordgrass habitat in North Carolina, USA. Marine Ecology Progress Series 56:111-118.

Kneib, R.T. 1986. The role of Fundulus heteroclitus in salt marsh trophic dynamics. American Zoologist 26:259-269.

Kneib R. T. and S. L. Wagner. 1994. Nekton use of vegetated marsh habitats at different stages of tidal inundation. Marine Ecology Progress Series 106:227-238.

Kushlan, J. A. 1974. Quantitative sampling of fish populations in shallow, freshwater environments. Transactions of the American Fisheries Society 103: 348-352.

LaSalle, M. W., M. C. Landin, and J. G. Sims. 1991. Evaluation of the flora and fauna of a Spartina alterniflora marsh established on dredged material in Winyah Bay, South Carolina. Wetlands 11(2):191-208.

Levinton, J. S. 1982. Marine Ecology. Prentice-Hall Publ. Co. Englewood Cliffs, NJ.

Mendelssohn, I. A. and N. L. Kuhn. 2003. Sediment subsidy: effects on soil-plant responses in a rapidly subsiding coastal salt marsh. Ecological Engineering 21(23):115-128.

Messaros, R. C., P. S. Rafferty and G. S. Woolley. 2010. Challenges and successes of tidal wetlands restoration in Jamaica Bay, New York. Watershed Management 2010: 343-363.

Mitsch, W. J. and R. F. Wilson. 1996. Improving success of wetland creation and restoration with know-how, time, and self-design. Ecological Applications 6:7783 .

Mitsch, W. J., X. Wu, R. W. Nairn, P. E. Weighe, N. Wang, R. Deal and C. E. Boucher. 1998. Creating and recovering wetlands: a whole ecosystem approach. BioScience 48:1019-1030.

Morris, J. T., P. V. Sundareshwar, C. T. Nietch, B. Kjerfve and D. R. Cahoon. 2002, Responses of coastal wetlands to rising sea level: Ecology 83(10): 2869-2877. 
National Park Service (NPS). 2001. The Jamaica Bay Blue Ribbon Panel on Marsh Loss and Coastal Sea Level Rise: A Future Agenda for Mitigation and Pilot Investigations. Brooklyn, NY: National Park Service, Gateway National Recreation Area.

National Park Service (NPS)-Gateway National Recreation Area and Aquatic Research and Environmental Assessment Center, Brooklyn College, CUNY. 2002. Jamaica Bay Ecosystem Research and Restoration Team (JABERRT) Final Report.

Neckles, H. A. and M. Dionne, Editors. 2000. Regional standards to identify and evaluate tidal wetland restoration in the Gulf of Maine. Wells National Estuarine Research Reserve Technical Report, Wells, ME. 21 pp. plus appendices.

New, T. R. 1998. Invertebrate surveys for conservation. New York, NY: Oxford University Press.

New York City Department of Environmental Protection (NYCDEP). 2015. Four Major Indicators of Environmental Change. Available at http://www.nyc.gov/html/dep/pdf/harbor/harbor_sampling_definitions.pdf

Peterson, G. W. and R. E. Turner. 1994. The value of salt marsh edge vs. interior as a habitat for fish and decapod crustaceans in a Louisiana tidal marsh. Estuaries 17(1B): 235-262.

Race, M. S. and M. S. Fonseca. 1996. Fixing compensatory mitigation: what will it take? Ecological Applications 6(1): 94-101.

Rafferty, P., J. Castagna and D. Adamo. 2010. Restoration Journal: Building partnerships to restore an urban marsh ecosystem at Gateway National Recreation Area. Park Science. 27(3): Winter 2010-2011.

Raposa, K. B. and C. T. Roman. 2001. Monitoring nekton in shallow estuarine habitats: Part of a series of monitoring protocols for the Long-term Coastal Ecosystem Monitoring Program at Cape Cod National Seashore. USGS Patuxent Wildlife Research Center, Coastal Research Field Station, University of Rhode Island, Narragansett, RI 02882.

Roberts, L. 1993. Wetlands trading is a loser's game, say ecologists. Science 260(25): 1890-1892.

Roman, C. T., M. J. James-Pirri, and J. F. Heltshe. 2001. Monitoring salt marsh vegetation: A protocol for the long-term coastal ecosystem monitoring program at Cape Cod National Seashore. USGS Patuxent Wildlife Research Center and Cape Cod National Seashore. 47pp.

Rozas, L. P. and W. E. Odum. 1987. Fish and macrocrustacean use of submerged plant beds in tidal freshwater marsh creeks. Marine Ecology Progress Series 38:101108.

Sacco J. N., E. D. Seneca and T. Wentworth. 1994. Infaunal community development of artificially established salt marshes in North Carolina. Estuaries 17:489-500. 
Shafer, D. J. and W. J. Streever. 2000. A comparison of 28 natural and dredged material salt marshes in Texas with an emphasis on geomorphological variables. Wetlands Ecology and Management 8:353-366.

Silberhorn, G. 1982. Common plants of the Mid-Atlantic Coast: A Field Guide. Baltimore, MD: The Johns Hopkins University Press.

Streever, W. J. 2000. Spartina alterniflora marshes on dredged material: a critical review of the ongoing debate over success. Wetlands Ecology and Management 8:295-316.

Sturdevant, A., C. B. Craft, J. N. Sacco. 2002. Ecological functions of an impounded marsh and three natural estuarine marshes along Woodbridge River, NY/NJ Harbor. Urban Ecosystems 6:163-181.

Swanson, R. L. and R. E. Wilson. 2008. Increased tidal ranges coinciding with Jamaica Bay development contribute to marsh flooding. Journal of Coastal Research 24(6):1565-1569.

Teal, J.M. and L. Weishar. 2005. Ecological engineering, adaptive management, and restoration management in Delaware Bay salt marsh restoration. Ecological Engineering 25(3):304-314.

United States Army Corps of Engineers - New York District (USACE-NYD). 2006. Jamaica Bay Marsh Islands, Jamaica Bay, NY, Integrated Ecosystem Restoration Report. Prepared in cooperation with the Port Authority of New York and New Jersey.

United States Army Corps of Engineers - New York District (USACE-NYD). 2007. Monitoring and Adaptive Management Plan: Jamaica Bay Marsh Islands Ecosystem Restoration. Prepared in Cooperation with National Park Service, New York State Department of Environmental Conservation, New York City Department of Environmental Protection, New York New Jersey Port Authority, and New York State Department of State. Working Document. January 2007.

United States Army Corps of Engineers - New York District (USACE-NYD). 2008. Elders Point East Settlement Analysis: Summary of Methods Report. Jamaica Bay, New York. Prepared by Bioengineering Group.

Walls, E. A., J. Berkson, and S. A. Smith. 2002. The Horseshoe Crab, Limulus Polyphemus: 200 Million Years of Existence, 100 Years of Study. Reviews in Fisheries Science 10 (1): 39-73.

Watson D. I. and D. K. A. Barnes. 2004. Quantifying Assemblage Distinctness with Time: An Example Using Temperate Epibenthos. Journal of Experimental Marine Biology \& Ecology 312: 367-383.

Weinstein, M. P. 1979. Shallow marsh habitats as primary nurseries for fishes and shellfish, Cape Fear River, North Carolina. Fishery Bulletin 77:339-357.

Wigand, C., C. T. Roman, E. Davey, M. Stolt, R. Johnson, A Hanson, E. B. Watson, S. B. Moran, D. R. Cahoon, J. C. Lynch and P. Rafferty. 2014. Below the disappearing marshes of an urban estuary: historic nitrogen trends and soil structure. Ecological Applications 24(4):633-649. 
Yozzo, D. J. and D. E. Smith. 1998. Composition and abundance of resident marshsurface nekton: comparison between tidal freshwater and salt marshes in Virginia, USA. Hydrobiologia 362:9-19.

Yozzo, D. J., and F. Ottman. 2003. New distribution records for the spotfin killifish (Fundulus luciae Baird) in the lower Hudson River Estuary and adjacent waters. Northeastern Naturalist 10:399-408.

Yozzo, D. J., P. Wilber, and R. J. Will. 2004. Beneficial use of dredged material for habitat creation, enhancement, and restoration in New York-New Jersey Harbor. Journal of Environmental Management 73(1):39-52. 


\section{Appendix A}

Table A-1. Vegetation percent cover treatment comparison.

\begin{tabular}{|c|c|c|}
\hline \multirow[b]{2}{*}{ Year } & \multicolumn{2}{|c|}{ Treatment Comparison ( $\mathrm{p}$ value) } \\
\hline & $\begin{array}{c}\text { Elders } \\
\text { vs } \\
\text { JoCo }\end{array}$ & $\begin{array}{c}\text { Fert } \\
\text { vs } \\
\text { No Fert }\end{array}$ \\
\hline 2005 & 0.001 & $\mathrm{n} / \mathrm{a}$ \\
\hline 2006 & 0.001 & $n / a$ \\
\hline 2007 & 0.001 & 0.001 \\
\hline 2008 & 0.002 & 0.002 \\
\hline 2009 & 0.004 & 0.022 \\
\hline 2010 & 0.108 & 0.060 \\
\hline 2012 & 0.133 & 0.088 \\
\hline \multicolumn{3}{|c|}{$\begin{array}{l}\text { Null hypothesis: No difference in total percent cove } \\
\text { of live vegetation between sites }\end{array}$} \\
\hline \multicolumn{3}{|c|}{ Significant $(p<0.05)$ difference between sites } \\
\hline
\end{tabular}

Table A-2. Vegetation stem density treatment comparison.

\begin{tabular}{|c|c|c|}
\hline \multirow{2}{*}{ Year } & \multicolumn{2}{|c|}{ Treatment Comparison ( $p$ value) } \\
\cline { 2 - 3 } & $\begin{array}{c}\text { Elders } \\
\text { vs } \\
\text { JoCo }\end{array}$ & $\begin{array}{c}\text { Fert } \\
\text { vs } \\
\text { No Fert }\end{array}$ \\
\hline 2005 & 0.002 & $\mathrm{n} / \mathrm{a}$ \\
\hline 2006 & 0.001 & $\mathrm{n} / \mathrm{a}$ \\
\hline 2007 & 0.001 & 0.012 \\
\hline 2008 & 0.001 & 0.001 \\
\hline 2009 & 0.001 & 0.001 \\
\hline 2010 & 0.001 & 0.013 \\
\hline 2012 & 0.098 & 0.612 \\
\hline $\begin{array}{l}\text { Null hypothesis: No difference in total stem density } \\
\text { of live vegetation between sites }\end{array}$ \\
\hline \multicolumn{2}{|l}{ Significant ( $\boldsymbol{p}<$ 0.05) difference between sites } \\
\hline
\end{tabular}


Table A-3. Vegetation stem height treatment comparison.

\begin{tabular}{|c|c|c|}
\hline \multirow[b]{2}{*}{ Year } & \multicolumn{2}{|c|}{ Treatment Comparison ( $p$ value) } \\
\hline & $\begin{array}{l}\text { Elders } \\
\text { vs } \\
\text { JoCo }\end{array}$ & $\begin{array}{c}\text { Fert } \\
\text { vs } \\
\text { No Fert }\end{array}$ \\
\hline 2005 & $\mathrm{n} / \mathrm{a}$ & $\mathrm{n} / \mathrm{a}$ \\
\hline 2006 & 0.001 & $\mathrm{n} / \mathrm{a}$ \\
\hline 2007 & 0.001 & 0.001 \\
\hline 2008 & 0.001 & 0.804 \\
\hline 2009 & 0.001 & 0.673 \\
\hline 2010 & 0.001 & 0.006 \\
\hline 2012 & 0.001 & 0.001 \\
\hline \multicolumn{3}{|c|}{$\begin{array}{l}\text { Null hypothesis: No difference in stem height-to-lea } \\
\text { of Spartina alterniflora between sites }\end{array}$} \\
\hline \multicolumn{3}{|c|}{ Significant $(p<0.05)$ difference between sites } \\
\hline
\end{tabular}

Table A-4. Vegetation aboveground biomass treatment comparison.

\begin{tabular}{|c|c|c|}
\hline \multirow[b]{2}{*}{ Year } & \multicolumn{2}{|c|}{ Treatment Comparison ( $p$ value) } \\
\hline & $\begin{array}{l}\text { Elders } \\
\text { vs } \\
\text { JoCo }\end{array}$ & $\begin{array}{c}\text { Fert } \\
\text { vs } \\
\text { No Fert }\end{array}$ \\
\hline 2005 & 0.001 & $\mathrm{n} / \mathrm{a}$ \\
\hline 2006 & 0.001 & $\mathrm{n} / \mathrm{a}$ \\
\hline 2007 & 0.001 & 0.002 \\
\hline 2008 & 0.049 & 0.199 \\
\hline 2009 & 0.358 & 0.128 \\
\hline 2010 & 0.226 & 0.137 \\
\hline 2012 & 0.728 & 0.059 \\
\hline \multicolumn{3}{|c|}{$\begin{array}{l}\text { Null hypothesis: No difference in aboveground } \\
\text { biomass between sites }\end{array}$} \\
\hline \multicolumn{3}{|c|}{ Significant $(p<0.05)$ difference between sites } \\
\hline
\end{tabular}


Table A-5. Vegetation belowground biomass $(0-15 \mathrm{~cm})$ treatment comparison.

\begin{tabular}{|c|c|c|}
\hline \multirow[b]{2}{*}{ Year } & \multicolumn{2}{|c|}{ Treatment Comparison ( $p$ value) } \\
\hline & $\begin{array}{l}\text { Elders } \\
\text { vs } \\
\text { JoCo }\end{array}$ & $\begin{array}{c}\text { Fert } \\
\text { vs } \\
\text { No Fert }\end{array}$ \\
\hline 2005 & 0.001 & $\mathrm{n} / \mathrm{a}$ \\
\hline 2006 & 0.001 & $\mathrm{n} / \mathrm{a}$ \\
\hline 2007 & 0.001 & 0.196 \\
\hline 2008 & 0.001 & 0.225 \\
\hline 2009 & 0.001 & 0.309 \\
\hline 2010 & 0.001 & 0.898 \\
\hline 2012 & 0.001 & 0.090 \\
\hline \multicolumn{3}{|c|}{$\begin{array}{l}\text { Null hypothesis: No difference in upper }(0-15 \mathrm{~cm}) \\
\text { belowground biomass between sites }\end{array}$} \\
\hline \multicolumn{3}{|c|}{ Significant $(p<0.05)$ difference between sites } \\
\hline
\end{tabular}

Table A-6. Vegetation belowground biomass $(15-30 \mathrm{~cm})$ treatment comparison.

\begin{tabular}{|c|c|c|}
\hline \multirow[b]{2}{*}{ Year } & \multicolumn{2}{|c|}{ Treatment Comparison ( $p$ value) } \\
\hline & $\begin{array}{c}\text { Elders } \\
\text { vs } \\
\text { JoCo }\end{array}$ & $\begin{array}{c}\text { Fert } \\
\text { vs } \\
\text { No Fert }\end{array}$ \\
\hline 2005 & 0.001 & $\mathrm{n} / \mathrm{a}$ \\
\hline 2006 & 0.001 & $\mathrm{n} / \mathrm{a}$ \\
\hline 2007 & 0.001 & 0.352 \\
\hline 2008 & 0.001 & 0.072 \\
\hline 2009 & 0.001 & 0.311 \\
\hline 2010 & 0.001 & 0.352 \\
\hline 2012 & 0.001 & 0.165 \\
\hline \multicolumn{3}{|c|}{$\begin{array}{l}\text { Null hypothesis: No difference in lower }(15-30 \mathrm{~cm}) \\
\text { belowground biomass between sites }\end{array}$} \\
\hline \multicolumn{3}{|c|}{ Significant $(p<0.05)$ difference between sites } \\
\hline
\end{tabular}


Table A-7. Benthic density treatment comparison.

\begin{tabular}{|c|c|c|}
\hline \multirow[b]{2}{*}{ Year } & \multicolumn{2}{|c|}{ Treatment Comparison ( $p$ value) } \\
\hline & $\begin{array}{l}\text { Elders } \\
\text { vs } \\
\text { JoCo }\end{array}$ & $\begin{array}{l}\text { Fert } \\
\text { vs } \\
\text { No Fert }\end{array}$ \\
\hline 2005 & 0.008 & $\mathrm{n} / \mathrm{a}$ \\
\hline 2006 & 0.007 & $\mathrm{n} / \mathrm{a}$ \\
\hline 2007 & 0.056 & 0.624 \\
\hline 2008 & 0.046 & 0.322 \\
\hline 2009 & 0.170 & 0.301 \\
\hline 2010 & 0.017 & 0.610 \\
\hline 2012 & 0.845 & 0.621 \\
\hline \multicolumn{3}{|c|}{$\begin{array}{l}\text { Null hypothesis: No difference in total benthic densit) } \\
\text { between sites }\end{array}$} \\
\hline \multicolumn{3}{|c|}{ Significant $(p<0.05)$ difference between sites } \\
\hline
\end{tabular}

Table A-8. Nekton early summer (event 1) density treatment comparison.

\begin{tabular}{|c|c|c|c|}
\hline \multirow[b]{2}{*}{ Year } & \multicolumn{3}{|c|}{ Treatment Comparison ( $p$ value) } \\
\hline & $\begin{array}{c}\text { Elders East } \\
\text { vs } \\
\text { JoCo }\end{array}$ & $\begin{array}{l}\text { Elders East } \\
\text { vs } \\
\text { Elders Lower }\end{array}$ & $\begin{array}{c}\text { Elders Lower } \\
\text { vs } \\
\text { JoCo }\end{array}$ \\
\hline 2005 & 0.002 & $\mathrm{n} / \mathrm{a}$ & $\mathrm{n} / \mathrm{a}$ \\
\hline 2006 & 0.022 & $\mathrm{n} / \mathrm{a}$ & $\mathrm{n} / \mathrm{a}$ \\
\hline 2007 & 0.736 & 0.197 & 0.335 \\
\hline 2008 & 0.003 & 0.679 & 0.084 \\
\hline 2009 & 0.409 & 0.442 & 0.069 \\
\hline 2010 & 0.986 & 0.294 & 0.601 \\
\hline 2012 & $\mathrm{n} / \mathrm{a}$ & $\mathrm{n} / \mathrm{a}$ & $\mathrm{n} / \mathrm{a}$ \\
\hline \multicolumn{4}{|c|}{$\begin{array}{l}\text { Null hypothesis: No difference in total nekton density between sites during } \\
\text { early summer (event 1) }\end{array}$} \\
\hline \multicolumn{4}{|c|}{ Significant $(p<0.05)$ difference between sites } \\
\hline
\end{tabular}


Table A-9. Nekton late summer (event 2) density treatment comparison.

\begin{tabular}{|c|c|c|c|}
\hline \multirow{2}{*}{ Year } & $\begin{array}{c}\text { Elders East } \\
\text { vs } \\
\text { JoCo }\end{array}$ & $\begin{array}{c}\text { Elders East } \\
\text { vs } \\
\text { Elders Lower }\end{array}$ & $\begin{array}{c}\text { Elders Lower } \\
\text { vs } \\
\text { JoCo }\end{array}$ \\
\hline 2005 & 0.752 & $\mathrm{n} / \mathrm{a}$ & $\mathrm{n} / \mathrm{a}$ \\
\hline 2006 & 0.001 & $\mathrm{n} / \mathrm{a}$ & $\mathrm{n} / \mathrm{a}$ \\
\hline 2007 & 0.538 & 0.246 & 0.175 \\
\hline 2008 & 0.012 & 0.081 & 0.942 \\
\hline 2009 & 0.076 & 0.376 & 0.059 \\
\hline 2010 & 0.429 & 0.149 & 0.645 \\
\hline 2012 & $\mathrm{n} / \mathrm{a}$ & $\mathrm{n} / \mathrm{a}$ & $\mathrm{n} / \mathrm{a}$ \\
\hline $\begin{array}{l}\text { Null hypothesis: No difference in total nekton density between sites during } \\
\text { late summer (event 2) }\end{array}$ \\
\hline \multicolumn{4}{|l|}{ Significant ( $<$ < 0.05) difference between sites } \\
\hline
\end{tabular}

Table A-10. Water quality early summer (event 1 ) dissolved oxygen treatment comparison.

\begin{tabular}{|c|c|c|c|}
\hline \multirow{2}{*}{ Year } & $\begin{array}{c}\text { Elders East } \\
\text { vs } \\
\text { JoCo }\end{array}$ & $\begin{array}{c}\text { Elders East } \\
\text { vs } \\
\text { Elders Lower }\end{array}$ & $\begin{array}{c}\text { Elders Lower } \\
\text { vs } \\
\text { JoCo }\end{array}$ \\
\hline 2005 & 0.001 & $\mathrm{n} / \mathrm{a}$ & $\mathrm{n} / \mathrm{a}$ \\
\hline 2006 & 0.001 & $\mathrm{n} / \mathrm{a}$ & $\mathrm{n} / \mathrm{a}$ \\
\hline 2007 & 0.027 & 0.001 & 0.002 \\
\hline 2008 & 0.001 & 0.001 & 0.111 \\
\hline 2009 & 0.080 & 0.001 & 0.012 \\
\hline 2010 & 0.004 & 0.226 & 0.001 \\
\hline 2012 & $\mathrm{n} / \mathrm{a}$ & $\mathrm{n} / \mathrm{a}$ & $\mathrm{n} / \mathrm{a}$ \\
\hline $\begin{array}{l}\text { Null hypothesis: No difference in dissolved oxygen between sites during early } \\
\text { summer (event 1) }\end{array}$ & \multicolumn{3}{|l}{} \\
\hline Significant $(\mathrm{p}<0.05)$ difference between sites \\
\hline
\end{tabular}


Table A-11. Water quality late summer (event 2) dissolved oxygen treatment comparison.

\begin{tabular}{|c|c|c|c|}
\hline \multirow{2}{*}{ Year } & $\begin{array}{c}\text { Elders East } \\
\text { vs } \\
\text { JoCo }\end{array}$ & $\begin{array}{c}\text { Elders East } \\
\text { vs } \\
\text { Elders Lower }\end{array}$ & $\begin{array}{c}\text { Elders Lower } \\
\text { vs } \\
\text { JoCo }\end{array}$ \\
\hline 2005 & 0.051 & $\mathrm{n} / \mathrm{a}$ & $\mathrm{n} / \mathrm{a}$ \\
\hline 2006 & 0.005 & $\mathrm{n} / \mathrm{a}$ & $\mathrm{n} / \mathrm{a}$ \\
\hline 2007 & 0.001 & 0.001 & 0.001 \\
\hline 2008 & 0.001 & 0.021 & 0.001 \\
\hline 2009 & 0.003 & 0.843 & 0.028 \\
\hline 2010 & 0.001 & 0.001 & 0.001 \\
\hline 2012 & $\mathrm{n} / \mathrm{a}$ & $\mathrm{n} / \mathrm{a}$ & $\mathrm{n} / \mathrm{a}$ \\
\hline $\begin{array}{l}\text { Null hypothesis: No difference in dissolved oxygen between sites during late } \\
\text { summer (event 2) }\end{array}$ & \multicolumn{3}{|l}{} \\
\hline \multicolumn{4}{|l|}{ Significant ( $<$ 0.05) difference between sites } \\
\hline
\end{tabular}

Table A-12. Water quality early summer (event 1 ) salinity treatment comparison.

\begin{tabular}{|l|c|c|c|}
\hline \multirow{2}{*}{ Year } & $\begin{array}{c}|c| \\
\text { Elders East } \\
\text { vs } \\
\text { JoCo }\end{array}$ & $\begin{array}{c}\text { Elders East } \\
\text { vs } \\
\text { Elders Lower }\end{array}$ & $\begin{array}{c}\text { Elders Lower } \\
\text { vs } \\
\text { JoCo }\end{array}$ \\
\hline 2005 & 0.057 & $\mathrm{n} / \mathrm{a}$ & $\mathrm{n} / \mathrm{a}$ \\
\hline 2006 & 0.003 & $\mathrm{n} / \mathrm{a}$ & $\mathrm{n} / \mathrm{a}$ \\
\hline 2007 & 0.066 & 0.003 & 0.065 \\
\hline 2008 & 0.004 & 0.014 & 0.400 \\
\hline 2009 & 0.099 & 0.658 & 0.207 \\
\hline 2010 & 0.004 & 0.010 & 0.174 \\
\hline 2012 & $\mathrm{n} / \mathrm{a}$ & $\mathrm{n} / \mathrm{a}$ & $\mathrm{n} / \mathrm{a}$ \\
\hline $\begin{array}{l}\text { Null hypothesis: No difference in salinity between sites during early summer } \\
\text { (event 1) }\end{array}$ & \multicolumn{4}{|l}{ Significant ( $<$ 0.05) difference between sites } \\
\hline
\end{tabular}


Table A-13. Water quality late summer (event 2) salinity treatment comparison.

\begin{tabular}{|l|c|c|c|}
\hline \multirow{2}{*}{ Year } & $\begin{array}{c}|c| \\
\text { Elders East } \\
\text { vs } \\
\text { JoCo }\end{array}$ & $\begin{array}{c}\text { Elders East } \\
\text { vs } \\
\text { Elders Lower }\end{array}$ & $\begin{array}{c}\text { Elders Lower } \\
\text { vs } \\
\text { JoCo }\end{array}$ \\
\hline 2005 & 0.377 & $\mathrm{n} / \mathrm{a}$ & $\mathrm{n} / \mathrm{a}$ \\
\hline 2006 & 0.098 & $\mathrm{n} / \mathrm{a}$ & $\mathrm{n} / \mathrm{a}$ \\
\hline 2007 & 0.352 & 0.232 & 0.083 \\
\hline 2008 & 0.001 & 0.347 & 0.001 \\
\hline 2009 & 0.124 & 0.189 & 0.006 \\
\hline 2010 & 0.001 & 0.914 & 0.004 \\
\hline 2012 & $\mathrm{n} / \mathrm{a}$ & $\mathrm{n} / \mathrm{a}$ & $\mathrm{n} / \mathrm{a}$ \\
\hline $\begin{array}{l}\text { Null hypothesis: No difference in salinity between sites during late summer } \\
\text { (event 2) }\end{array}$ & \multicolumn{4}{l}{} \\
\hline \multicolumn{4}{|l}{ Significant ( $<$ < 0.05) difference between sites } \\
\hline
\end{tabular}

Table A-14. Water quality early summer (event 1 ) temperature treatment comparison.

\begin{tabular}{|c|c|c|c|}
\hline \multirow{2}{*}{ Year } & $\begin{array}{c}\text { Elders East } \\
\text { vs } \\
\text { JoCo }\end{array}$ & $\begin{array}{c}\text { Elders East } \\
\text { vs } \\
\text { Elders Lower }\end{array}$ & $\begin{array}{c}\text { Elders Lower } \\
\text { vs } \\
\text { JoCo }\end{array}$ \\
\hline 2005 & 0.018 & $\mathrm{n} / \mathrm{a}$ & $\mathrm{n} / \mathrm{a}$ \\
\hline 2006 & 0.001 & $\mathrm{n} / \mathrm{a}$ & $\mathrm{n} / \mathrm{a}$ \\
\hline 2007 & 0.001 & 0.006 & 0.008 \\
\hline 2008 & 0.146 & 0.253 & 0.115 \\
\hline 2009 & 0.010 & 0.001 & 0.063 \\
\hline 2010 & 0.039 & 0.207 & 0.063 \\
\hline 2012 & $\mathrm{n} / \mathrm{a}$ & $\mathrm{n} / \mathrm{a}$ & $\mathrm{n} / \mathrm{a}$ \\
\hline $\begin{array}{l}\text { Null hypothesis: No difference in water temperature between sites during } \\
\text { early summer (event 1) }\end{array}$ & \multicolumn{3}{l}{} \\
\hline Significant ( $<$ < 0.05) difference between sites \\
\hline
\end{tabular}


Table A-15. Water quality late summer (Event 2) temperature treatment comparison.

\begin{tabular}{|c|c|c|c|}
\hline \multirow{2}{*}{ Year } & $\begin{array}{c}\text { Elders East } \\
\text { vs } \\
\text { JoCo }\end{array}$ & $\begin{array}{c}\text { Elders East } \\
\text { vs } \\
\text { Elders Lower }\end{array}$ & $\begin{array}{c}\text { Elders Lower } \\
\text { vs } \\
\text { JoCo }\end{array}$ \\
\hline 2005 & 0.001 & $\mathrm{n} / \mathrm{a}$ & $\mathrm{n} / \mathrm{a}$ \\
\hline 2006 & 0.654 & $\mathrm{n} / \mathrm{a}$ & $\mathrm{n} / \mathrm{a}$ \\
\hline 2007 & 0.001 & 0.004 & 0.010 \\
\hline 2008 & 0.001 & 0.565 & 0.001 \\
\hline 2009 & 0.016 & 0.006 & 0.024 \\
\hline 2010 & 0.018 & 0.001 & 0.001 \\
\hline 2012 & $\mathrm{n} / \mathrm{a}$ & $\mathrm{n} / \mathrm{a}$ & $\mathrm{n} / \mathrm{a}$ \\
\hline $\begin{array}{l}\text { Null hypothesis: No difference in water temperature between sites during late } \\
\text { summer (event 2) }\end{array}$ \\
\hline \multicolumn{5}{l}{ Significant ( $\mathrm{p}<0.05$ ) difference between sites } \\
\hline
\end{tabular}




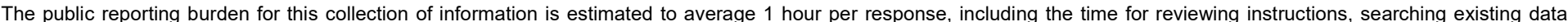

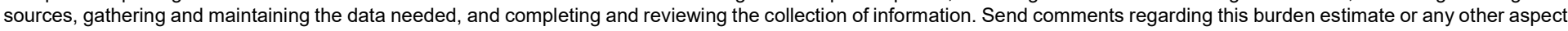

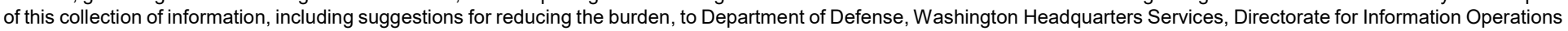

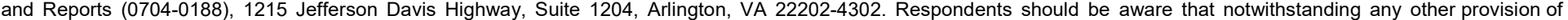
law, no person shall be subject to any penalty for failing to comply with a collection of information if it does not display a currently valid OMB control number.

PLEASE DO NOT RETURN YOUR FORM TO THE ABOVE ADDRESS.

\begin{tabular}{l|l|l}
\hline $\begin{array}{l}\text { 1. REPORT DATE } \\
\text { September } 2017\end{array}$ & 2. REPORT TYPE & 3. DATES COVERED (FrOm - To)
\end{tabular}

\section{TITLE AND SUBTITLE}

Elders Point East Marsh Island Restoration

Monitoring Data Analysis

Final Report

\section{5a. CONTRACT NUMBER}

\section{5b. GRANT NUMBER}

NA

5c. PROGRAM ELEMENT NUMBER

NA

\section{AUTHOR(S)}

David S. Davis, Peter M. Weppler, Patricia Rafferty, Douglas G. Clarke, and David Yozzo

\section{5d. PROJECT NUMBER 454750}

5e. TASK NUMBER

NA

5f. WORK UNIT NUMBER

NA

\section{PERFORMING ORGANIZATION} REPORT NUMBER

ERDC/EL CR-17-1
7. PERFORMING ORGANIZATION NAME(S) AND ADDRESS(ES)

USACE New York District, 26 Federal Plaza, New York, NY

US Park Service,

Engineer Research and Development Center, 3909 Halls ferry Rd, Vicksburg, MS 39180

9. SPONSORING/MONITORING AGENCY NAME(S) AND ADDRESS(ES)

U.S. Army Corps of Engineers

New York District, Planning Division

26 Federal Plaza, Room 2151

New York, NY 10278-0090

\section{CENAN}

11. SPONSOR/MONITOR'S REPORT NUMBER(S)

Not Applicable

\section{DISTRIBUTION/AVAILABILITY STATEMENT}

Approved for public release; distribution is unlimited.

\section{SUPPLEMENTARY NOTES}

\section{ABSTRACT}

Chronic loss of intertidal salt marsh island habitat in Jamaica Bay, New York, has led to efforts by multi-agency partnerships to reduce loss through habitat restoration. A 2006 USACE New York District report recommended restoration of three marsh islands within the Jamaica Bay Unit of Gateway National Recreation Area: Elders Point East, Elders Point West, and Yellow Bar Hassock.

USACE New York District and its local sponsor, the Port Authority of New York and New Jersey, utilized sand obtained from navigation dredging and commercial sources to (1) return approximately 16 hectares (40 acres) of bay area to full Spartina alterniflora marsh and wetland functionality, and (2) test a suite of management practices to enhance the probability of long-term success.

Although the long-term success of the Elders Point East Marsh restoration project cannot be confirmed by the 2007-2012 term of postconstruction monitoring, nearly all lines of evidence gathered to date indicate that the marsh is following a functional equivalency trajectory toward an endpoint comparable to reference conditions. In this case, the beneficial use of dredged material proved to be a viable option for restoration of sufficient habitat area to substantially enhance lost ecological function within the Jamaica Bay ecosystem.

\section{SUBJECT TERMS}

Marsh Restoration, Dredged Material, Jamaica Bay, Beneficial Use, Habitat, Benthic Macroinvertebrates, Birds, Fish

\begin{tabular}{|c|c|c|c|c|c|}
\hline \multicolumn{3}{|c|}{ 16. SECURITY CLASSIFICATION OF: } & \multirow{3}{*}{$\begin{array}{l}\text { 17. LIMITATION OF } \\
\text { ABSTRACT } \\
\text { SAR }\end{array}$} & \multirow{3}{*}{$\begin{array}{l}\text { 18. NUMBER OF } \\
\text { PAGES } \\
95\end{array}$} & \multirow{2}{*}{$\begin{array}{l}\text { 19a. NAME OF RESPONSIBLE PERSON } \\
\text { Weppler }\end{array}$} \\
\hline a. REPORT & b. ABSTRACT C & THIS & & & \\
\hline & & Unlimited & & & 19b. TELEPHONE NUMBER (Include area code) \\
\hline
\end{tabular}

